ZENTRUM FÜR BIODIVERSITÄT UND NACHHALTIGE LANDNUTZUNG

SEKTION BIODIVERSITÄT, ÖKOLOGIE UND NATURSCHUTZ

CENTRE OF BIODIVERSITY AND SUSTAINABLE LAND USE

SECTION BIODIVERSITY, ECOLOGY AND NATURE CONSERVATION

\title{
NITROGEN RESPONSE EFFICIENCY, NITROGEN RETENTION EFFICIENCY, AND ASYMBIOTIC BIOLOGICAL NITROGEN FIXATION OF A TEMPERATE PERMANENT GRASSLAND SITE UNDER DIFFERENT SWARD COMPOSITIONS AND MANAGEMENT PRACTICES
}

DisSERTATION ZUR ERLANGUNG DES DOKTORGRADES DER MATHEMATISCHNATURWISSENSCHAFTLICHEN FAKULTÄTEN DER GEORG-AUGUST-UNIVERSITÄT GÖTTINGEN

VORGELEGT VON

Dipl. GEOGR. ANDREAs KeUteR, M.SC.

AUS

WARENDORF

GöTTINGEN, 08.01.2013 
Referent: Prof. Dr. Edzo Veldkamp

Korreferentin: Dr. Marife D. Corre

Tag der Disputation: 08.01.2013 


\section{Table of contents}

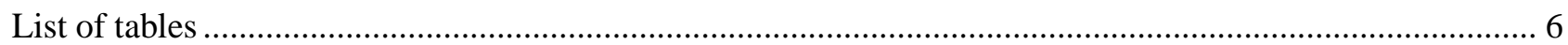

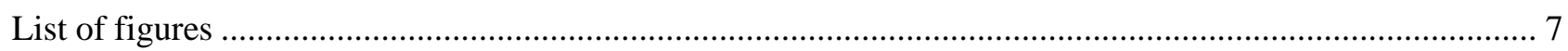

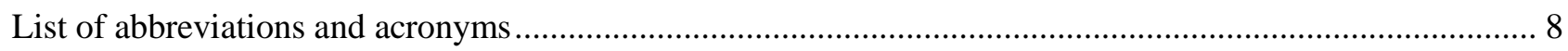

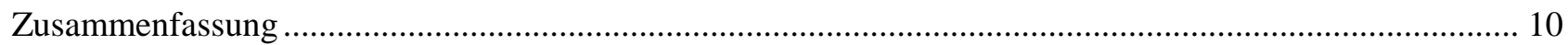

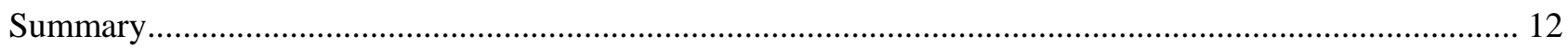

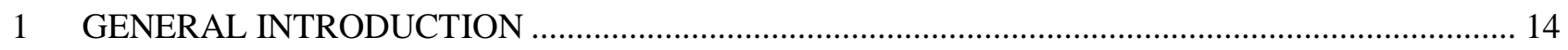

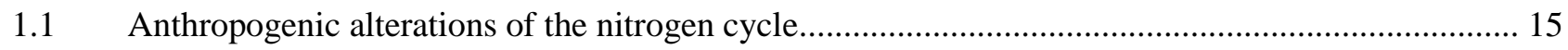

1.2 Temperate grasslands-management and consequences for the $\mathrm{N}$ cycle.......................................... 16

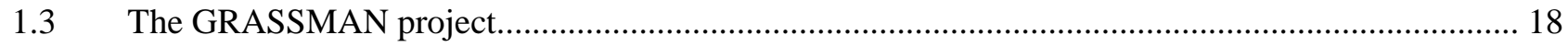

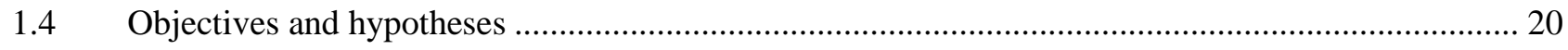

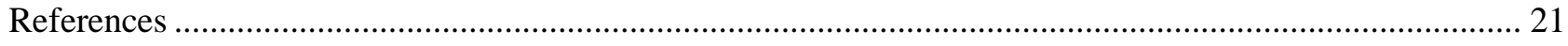

2 NITROGEN RESPONSE EFFICIENCY OF A MANAGED AND PHYTODIVERSE TEMPERATE

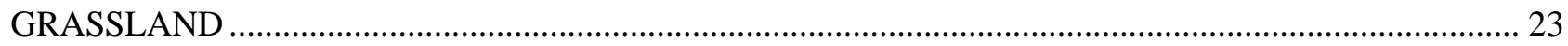

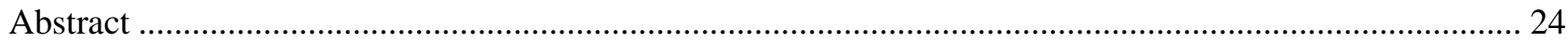

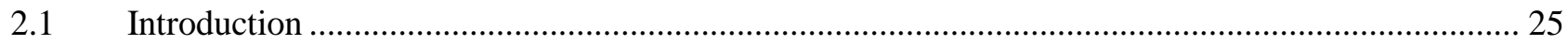

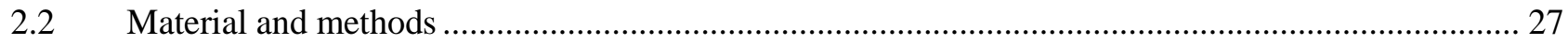

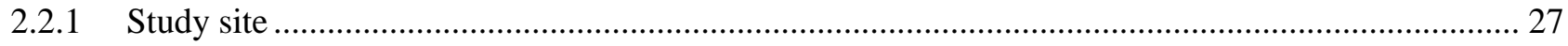

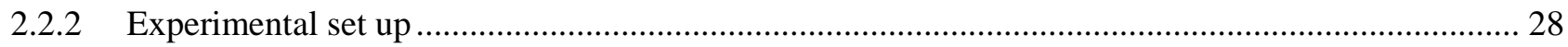

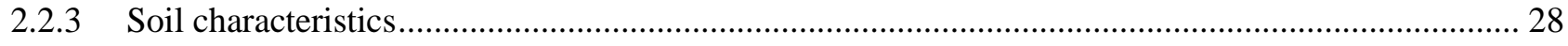

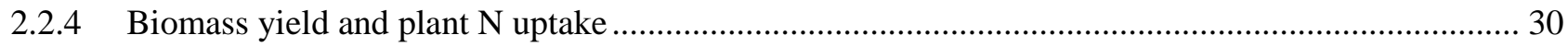

2.2.5 Soil net $\mathrm{N}$ mineralization rates, $\mathrm{N}$ supply, and $\mathrm{N}$ response efficiency ............................................ 30

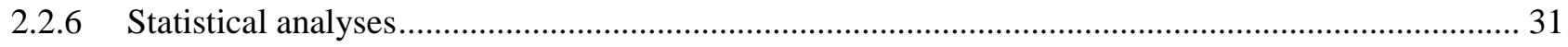

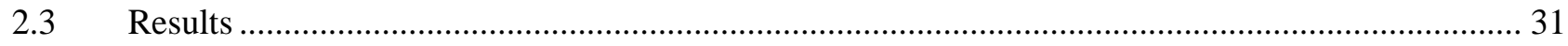

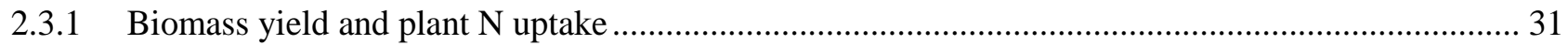

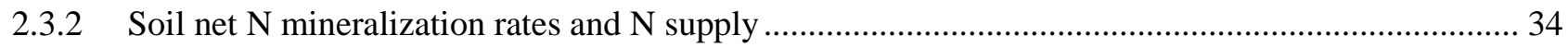

2.3.3 N response efficiency, $\mathrm{N}$ uptake efficiency and $\mathrm{N}$ use efficiency …............................................... 36

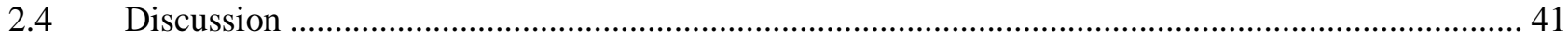

2.4.1 Soil net $\mathrm{N}$ mineralization, plant $\mathrm{N}$ uptake and biomass yield.......................................................... 41

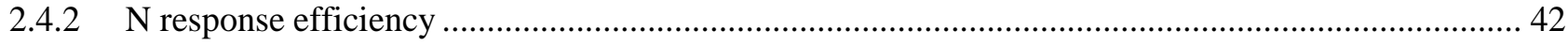

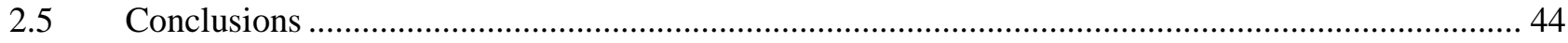

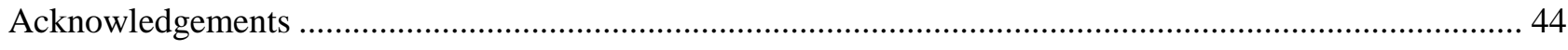

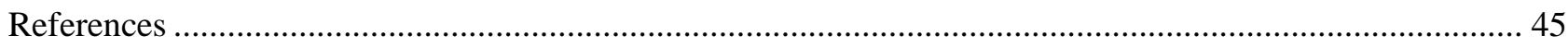

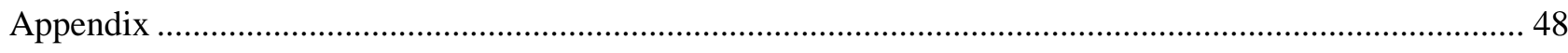

3 NITROGEN RETENTION EFFICIENCY AND NITROGEN LOSSES OF A MANAGED AND

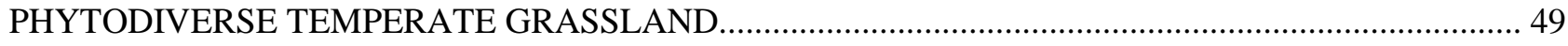

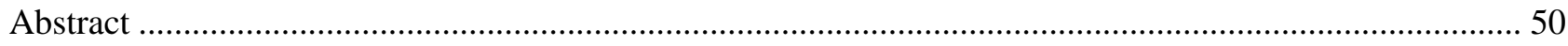




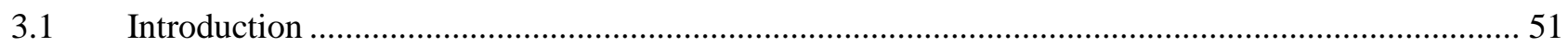

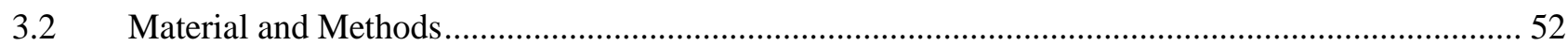

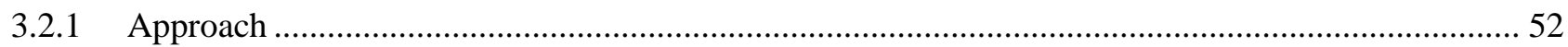

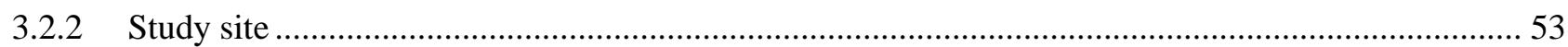

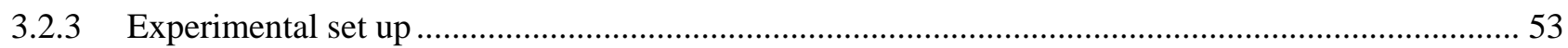

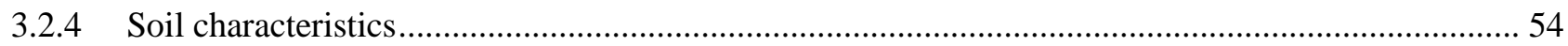

3.2.5 Gross $\mathrm{N}$ transformation rates and microbial biomass................................................................ 55

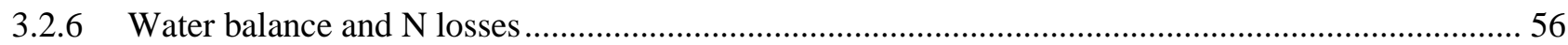

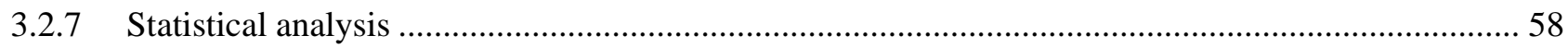

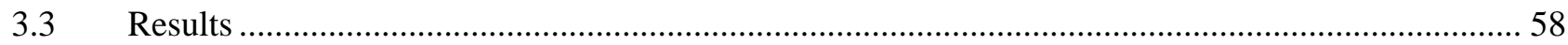

3.3.1 Gross $\mathrm{N}$ transformation rates and microbial biomass..................................................................... 58

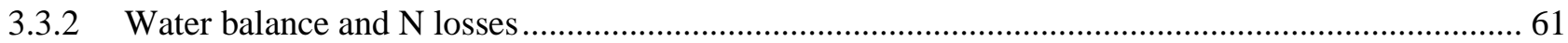

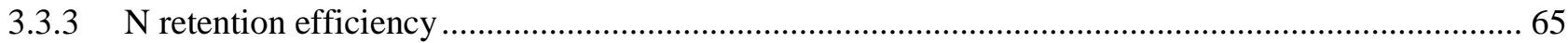

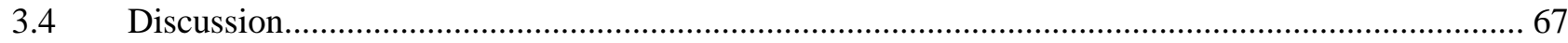

3.4.1 Gross N mineralization rates, immobilization rates and microbial biomass ................................... 67

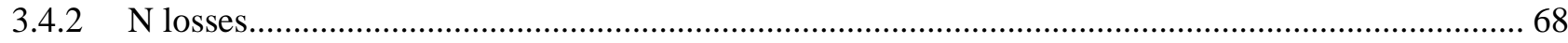

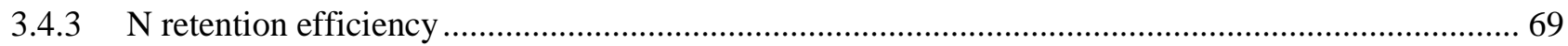

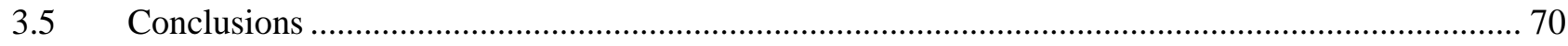

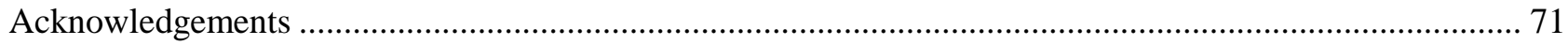

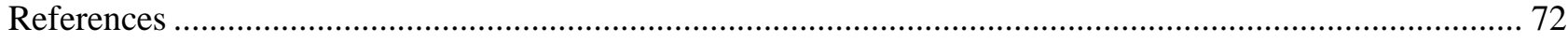

4 ASYMBIOTIC BIOLOGICAL NITROGEN FIXATION IN A TEMPERATE GRASSLAND UNDER DIFFERENT FERTILIZATION AND MOWING TREATMENTS........................................................... 75

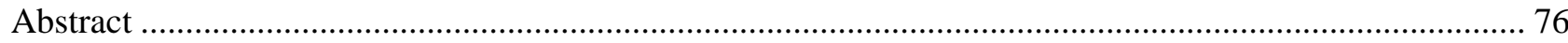

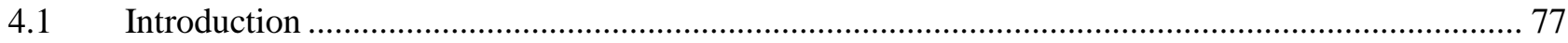

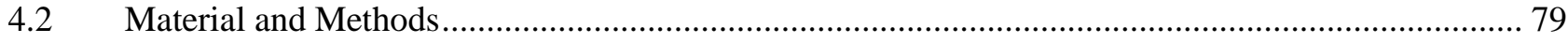

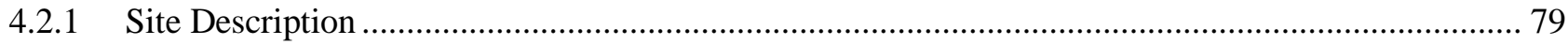

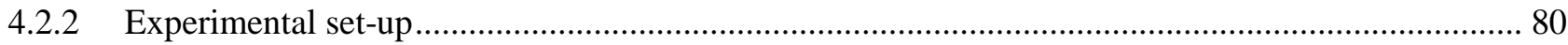

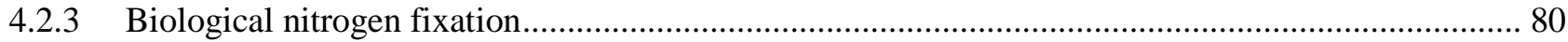

4.2.4 Test for endogenous $\mathrm{C}_{2} \mathrm{H}_{4}$ production and $\mathrm{C}_{2} \mathrm{H}_{4}$ consumption .................................................. 82

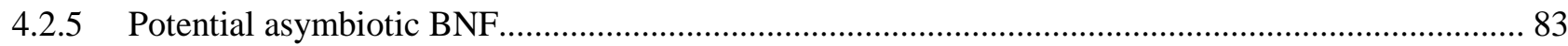

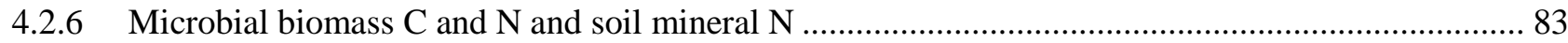

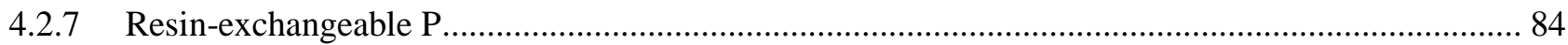

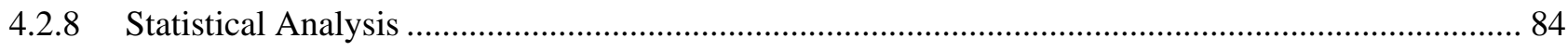

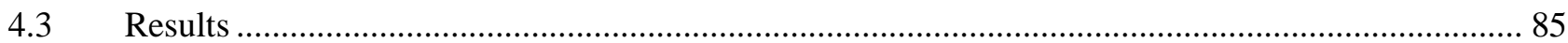

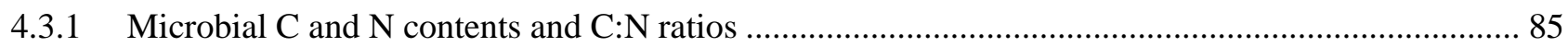

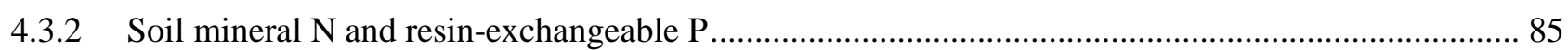

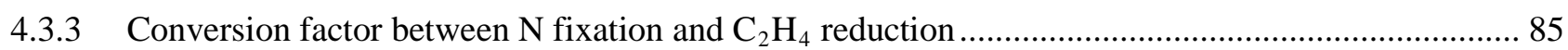

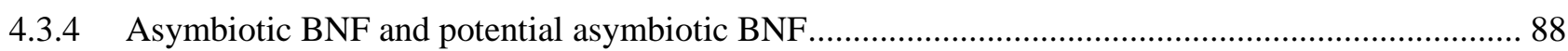




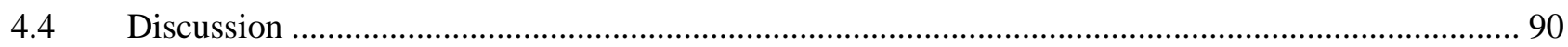

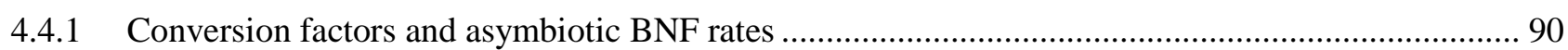

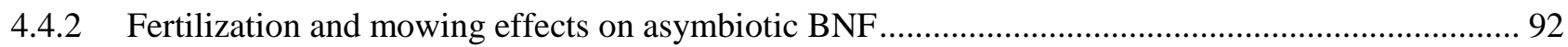

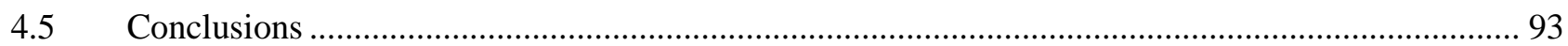

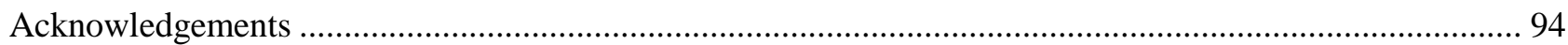

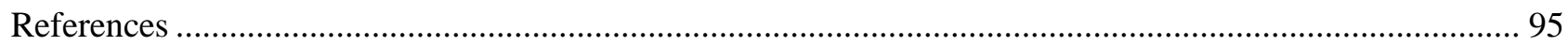

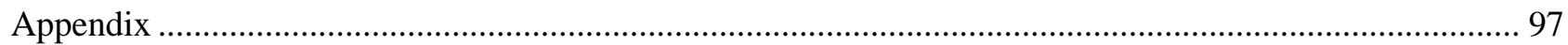

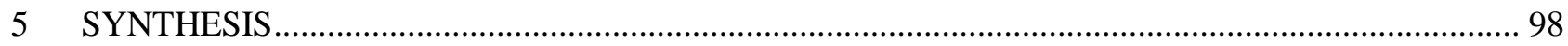

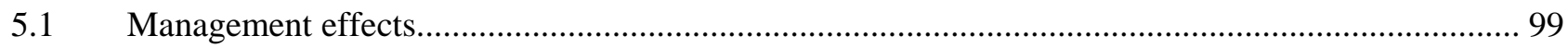

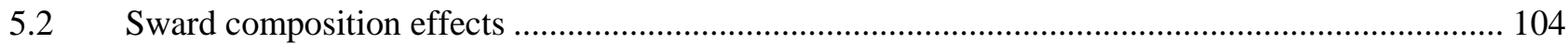

$5.3 \quad$ General Conclusions and Recommendations .............................................................................. 105

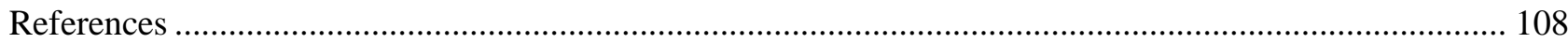

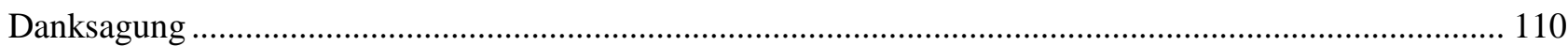

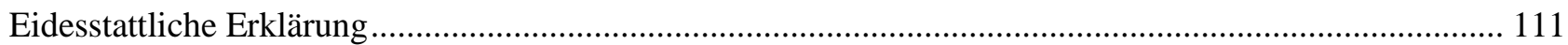

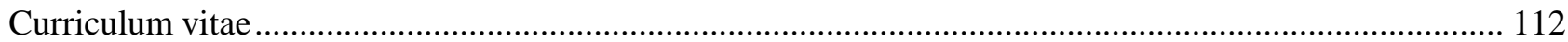




\section{List of tables}

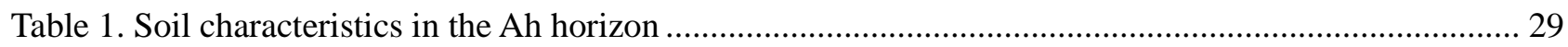

Table 2: Plant $\mathrm{N}$ uptake of a grassland under different management practices ............................................. 33

Table 3: Soil net $\mathrm{N}$ mineralization rates of a grassland under different management practices ...................... 35

Table 4: $\mathrm{N}$ response efficiency (NRE) of a grassland under different management practices ....................... 37

Table 5: $\mathrm{N}$ uptake efficiency of a grassland under different management practices ...................................... 38

Table 6: N use efficiency (NUE) of a grassland under different management practices............................... 39

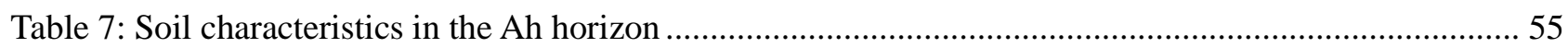

Table 8: Gross $\mathrm{N}$ mineralization rates, gross nitrification rates, $\mathrm{NH}_{4}{ }^{+}$immobilization rates, microbial C, microbial $\mathrm{N}$ and microbial $\mathrm{C}: \mathrm{N}$ ratios of a grassland under different management practices. ............... 60

Table 9: $\mathrm{N}$ retention efficiency of a grassland under different management practices................................... 66

Table 10: Correlations between $\mathrm{N}$ retention efficiency and different plant- and soil-microbial parameters... 66 


\section{List of figures}

Figure 1: Location of the GRASSMAN experimental site in the Solling uplands, Lower Saxony, Germany. 19

Figure 2: Experimental design of the GRASSMAN experiment.

Figure 3: Trends between $\mathrm{N}$ response efficiency and (a) $\mathrm{N}$ supply, (b) $\mathrm{N}$ uptake efficiency and (c) $\mathrm{N}$ use efficiency (NUE) of a grassland in the Solling Mountains, Germany 40

Figure 4: $\mathrm{NO}_{3}{ }^{-}$and DON leaching rates at 0.5-0.6 m mineral soil of a grassland under different management practices

Figure 5: $\mathrm{N}_{2} \mathrm{O}$ emissions of a grassland under different management practices

Figure 6: Soil microbial biomass carbon and nitrogen and microbial carbon : nitrogen ratios of a grassland under different fertilization treatments different mowing frequencies

Figure 7: Total soil mineral $\mathrm{N}$ and resin exchangeable $\mathrm{P}$ concentrations of a grassland under different fertilization treatments and different mowing frequencies

Figure 8: Rates of asymbiotic biological nitrogen fixation of a grassland under and different fertilization treatments and mowing frequencies

Figure 9: Potential asymbiotic biological nitrogen fixation of a grassland under different mowing frequencies and fertilization treatments .....

Figure 10: Nitrogen cycling of a grassland in the Solling uplands, Germany under different fertilization treatments. 101

Figure 11: Total N, microbial biomass $\mathrm{N}$ and gross $\mathrm{N}$ mineralization of a grassland in the Solling uplands, Germany. 


\section{List of abbreviations and acronyms}

AIC

ANOVA

ATP

$\mathrm{BaCl}_{2}$

BNF

C.

CEC

$\mathrm{C}_{2} \mathrm{H}_{2}$

$\mathrm{C}_{2} \mathrm{H}_{4}$

d.

DON

DIN

E.

ET

ha.

$\mathrm{H}_{2} \mathrm{O}$

$\mathrm{H}_{2} \mathrm{O}_{2}$

HSD.

I.

ICP-OES

IPCC

IRMS

K.

$\mathrm{K}_{2} \mathrm{SO}_{4}$

L.

LME.

Mo

mo

n.

$\mathrm{N}$

Na.

$\mathrm{N}_{\mathrm{r}}$.

$\mathrm{N}_{2}$
.Linear mixed effects model

.Akaike’s information criterion Analysis of variance .Adenosinetriphosphate Barium chloride Biological nitrogen fixation .Carbon

..Cation exchange capacity Acetylene Ethylene .Day .Dissolved organic nitrogen ..Dissolved inorganic nitrogen

..Evaporation Evapotranspiration Hectare .Water Hydrogen peroxide .Honestly significant difference ...Interception ..Inductively coupled plasma - optical emission spectroscopy .Intergovernmental Panel on Climate Change .Isotope ratio mass spectrometer Potassium Potassium sulphate ...Liter Molybdenum .Month Number of replicates .Nitrogen Sodium .Reactive nitrogen .Molecular dinitrogen 

Molecular dinitrogen, mass of $30 \mathrm{~g} \mathrm{~mole}^{-1}$

n.d. .Not determined

$\mathrm{NH}_{4}^{+}$ Ammonium

$\mathrm{NH}_{4} \mathrm{Cl}$ Ammonium chloride $\mathrm{NH}_{4} \mathrm{NO}_{3}$ Ammonium nitrate

$\mathrm{NO}$ ...Nitric oxide

$\mathrm{NO}_{3}$ Nitrate

$\mathrm{N}_{2} \mathrm{O}$ ...Nitrous oxide NPK ...Nitrogen, phosphorus and potassium fertilizer

NRE ..Nitrogen response efficiency

NUE Nitrogen use efficiency n.s. not significant P. .Phosphorus P. .Precipitation input $P$ .Significance level .Resin-exchangeable phosphorus .Polyvinyl chloride R. Surface runoff $\mathrm{R}^{2}$. ..Coefficient of determination S. .Drainage flux SE. Standard error SOM. ..Soil organic matter $\mathrm{T}$. ...Transpiration

UV .Ultraviolet WFPS. ..Water-filled pore space WRB. .World Reference Base for Soil Resources $\Delta \mathrm{W}$ Soil water storage yr. Year 


\section{Zusammenfassung}

Der globale Stickstoffkreislauf wurde in den letzten Jahrzehnten maßgeblich von anthropogenen Einflüssen - besonders der Produktion von reaktivem Stickstoff $(\mathrm{N})$ - geprägt. In europäischen Grasländern ging der vermehrte Einsatz von Stickstoffdüngern mit einer Erhöhung der Mahdfrequenzen einher. Diese landwirtschaftliche Intensivierung hat Grasländer zu wichtigen Quellen für Stickstoffverluste gemacht und zu einer Verminderung der Artenvielfalt geführt. Die Minimierung von Stickstoffverlusten bei gleichzeitiger Erhaltung von Bodenfruchtbarkeit und hohen Erträgen sind eine wichtige Herausforderung für die Graslandbewirtschaftung. Dies kann durch 1) eine effiziente Retention von bodenverfügbarem N im System Pflanze-Boden und 2) eine hohe N-Nutzungseffizienz (d.h. eine hohe pflanzliche Biomasseproduktion pro Einheit pflanzenverfügbaren Stickstoffs) erreicht werden. Die anthropogene Steigerung der Produktion von reaktivem $\mathrm{N}$ ist in der Fachliteratur umfassend dokumentiert. Das Verhältnis zwischen anthropogenen N-Einträgen und biologischer N-Fixierung ist jedoch unklar, da existierende Daten zur (asymbiotischen) N-Fixierung lückenhaft sind und nicht flächendeckend vorliegen.

Das Ziel der vorliegenden Arbeit ist es, den Einfluss von Bewirtschaftungsformen und funktionaler Pflanzendiversität auf N-Nutzungseffizienz, N-Verluste, N-Retentionseffizienz und asymbiotische biologische N-Fixierung in einem temperaten Grasland $\mathrm{zu}$ ermitteln. Ein dreifaktorielles Versuchsdesign mit drei Grasnarbenzusammensetzungen (mit unterschiedlichen Anteilen von Dicotyledonen und Monokotyledonen), zwei Mahdfrequenzen und zwei Düngeintensitäten wurde etabliert. Die N-Nutzungseffizienz wurde als Menge der geernteten Biomasse pro Einheit planzenverfügbaren Stickstoffs berechnet. Darüber hinaus wurde ein Index, der die NRetentionseffizienz als Ökosystemeigenschaft beschreibt und der N-Verluste in Relation zur BruttoN-Mineralisation (als einen Indikator für Bodenfruchtbarkeit) setzt, entwickelt. Die asymbiotische biologische N-Fixierung wurde an ungestörten Bodenkernen mit der Acetylenreduktionsmethode bestimmt. Dabei wurden Feld- und Laborinkubationen sowie eine Kalibration der Acetylenreduktionsmethode mit direkten, auf ${ }^{15} \mathrm{~N}_{2}$ Markierung basierenden Messungen, durchgeführt.

Die Ergebnisse zeigen, dass Düngung der einflussreichste der Faktoren ist und sowohl die N-Nutzungseffizienz als auch die mikrobielle N-Immobilisation verringert. Folglich resultiert Düngung in höheren N-Verlusten und einer niedrigeren N-Retentionseffizienz. Intensives Mähen kann dabei teilweise den durch Düngung verursachten höheren N-Verlusten entgegenwirken. Die unbehandelte Kontrollvegetation, die sich im Laufe jahrzehntelanger extensiver Bewirtschaftung entwickelt hat, weist neben der höchsten N-Nutzungseffizienz auch die höchste NRetentionseffizienz auf. Dies kann teilweise durch eine komplementäre Resourcennutzung erklärt werden, ist aber auch eine Folge von Unterschieden in der mikrobiellen Immobilisation von 
Ammonium, die den Ergebnissen zufolge der wichtigste Mechanismus für eine effiziente NRetention im System Pflanze-Boden ist. Die N-Retentionseffizienz berücksichtigt diesen Mechanismus und ist daher ein wichtiger Faktor für die Bewertung der Nachhaltigkeit von Graslandbewirtschaftungspraktiken. Die integrierende Betrachtung von N-Nutzungseffizienz und N-Retentionseffizienz berücksichtigt Biomasseerträge, Brutto-N-Mineralisation als einen Indikator für Bodenfruchtbarkeit und umweltschädliche N-Verluste. Demzufolge sind N-Nutzungseffizienz und N-Retentionseffizienz geeignete Parameter für die Bewertung der Nachhaltigkeit von Grünlandbewirtschaftungspraktiken, welche von Landwirten zur Profitmaximierung praktiziert werden.

Die Ergebnisse zeigen weiterhin, dass asymbiotische biologische N-Fixierung mit Mengen zwischen 1.5 und $4.9 \mathrm{~kg} \mathrm{ha}^{-1} \mathrm{yr}^{-1}$ in den oberen $5 \mathrm{~cm}$ des Bodenprofils eine signifikante N-Zufuhr darstellen kann. Düngung mit $\mathrm{N}$ und Phosphor (P) verringert dabei die asymbiotische biologische N-Fixierung. Potentiell positive Auswirkungen einer höheren P-Verfügbarkeit werden anscheinend von negativen Auswirkungen höherer Konzentrationen an mineralischem N unterdrückt. Häufiges Mähen fördert die asymbiotische biologische N-Fixierung, was wahrscheinlich auf eine erhöhte Rhizodeposition zurückzuführen ist. Die ${ }^{15} \mathrm{~N}_{2}$ Kalibration zeigt darüber hinaus, dass Umrechnungsfaktoren zwischen Acetylenreduktion und $\mathrm{N}_{2}$-Fixierung erheblich niedriger als der stöchiometrische Wert von drei sein können. Laborinkubationen mit erhöhter Bodenfeuchtigkeit und Temperatur führten zu einem starken Anstieg der asymbiotischen biologischen N-Fixierung. Bisherige Schätzungen der asymbiotischen biologischen N-Fixierung sind daher möglicherweise fehlerhaft. Die Ergebnisse zeigen, dass die asymbiotische biologische N-Fixierung für intensiv bewirtschaftete landwirtschaftliche Ökosysteme von untergeordneter Bedeutung ist. Global ist sie jedoch vermutlich ein wichtiger Pfad der biologischen N-Fixierung und trägt damit signifikant zur nicht-anthtropogenen Stickstofffixierung bei. 


\section{Summary}

Human activity had a huge impact on the global nitrogen $(\mathrm{N})$ cycle in the last decades, mainly through an increase in the production of reactive N. In European grasslands, the increased use of N fertilizers was accompanied by increased mowing frequencies. This agricultural intensification made grasslands important sources of $\mathrm{N}$ losses and caused a decrease in biodiversity. Minimizing $\mathrm{N}$ losses and maintaining both soil quality and high yields at the same time is an important challenge in grassland management. This can be achieved through 1) an efficient retention of soil available $\mathrm{N}$ in the plant-soil system and 2) a high $\mathrm{N}$ response efficiency (NRE; i.e. a high plant biomass production per unit of plant-available $\mathrm{N}$ ). The anthropogenic increase in the production of reactive $\mathrm{N}$ has been reviewed extensively. However, the comparison between anthropogenic $\mathrm{N}$ sources and biological $\mathrm{N}$ fixation (BNF) is difficult because existing data on (asymbiotic) BNF are incomplete and spatially unresolved.

In the present study, our goal was to assess how management practices and sward functional diversity affect NRE, $\mathrm{N}$ losses, $\mathrm{N}$ retention efficiency and asymbiotic BNF in a temperate grassland. A three-factorial design was employed: three sward compositions (differing in species richness and the proportion of dicots and monocots), two mowing frequencies, and two fertilization treatments. NRE was calculated as the amount of harvested biomass per unit of plant-available N. Additionally, we developed an index that describes $\mathrm{N}$ retention efficiency as an ecosystem property and that relates $\mathrm{N}$ losses to gross $\mathrm{N}$ mineralization as an index for soil fertility. Asymbiotic BNF was measured on intact soil cores incubated separately in the field and in the lab using the acetylene reduction assay calibrated against direct measurements with ${ }^{15} \mathrm{~N}_{2}$ label.

Fertilization was the dominant factor decreasing NRE and microbial $\mathrm{N}$ immobilization. Consequently, fertilization resulted in higher $\mathrm{N}$ losses and lower $\mathrm{N}$ retention efficiency. Intensive mowing partly reduced the high $\mathrm{N}$ losses following fertilization. Untreated control swards that have developed under decades of extensive management practices had the highest NRE and $\mathrm{N}$ retention efficiency. This pattern could be partly explained by complementary plant resource use. At the same time, it was also the result of the differences in microbial immobilization of ammonium which was the most important mechanism for an efficient $\mathrm{N}$ retention in the plant-soil system. $\mathrm{N}$ retention efficiency considers this pathway and thus, is a critical factor to consider when evaluating the sustainability of grassland management practices. The combined consideration of NRE and N retention efficiency provides a tool that accounts for biomass yield, gross $\mathrm{N}$ mineralization as a measure for soil fertility, and $\mathrm{N}$ losses to the environment. Thus, NRE and $\mathrm{N}$ retention efficiency are appropriate tools to evaluate the sustainability of grassland management practices which farmers employ to maximize profit. 
Our results showed that asymbiotic BNF can provide significant N inputs between 1.5 and $4.9 \mathrm{~kg}$ $\mathrm{ha}^{-1} \mathrm{yr}^{-1}$ in the top $0.05 \mathrm{~m}$ of the soil profile. Fertilization with $\mathrm{N}$ and $\mathrm{P}$ decreased asymbiotic BNF. Potentially positive effects of a higher $\mathrm{P}$ availability were probably counteracted by negative effects of higher mineral $\mathrm{N}$ concentrations. Intensive mowing stimulated asymbiotic BNF most likely through an increase in rhizodeposition. Moreover, the ${ }^{15} \mathrm{~N}_{2}$ calibration showed that the conversion factor between acetylene reduction and $\mathrm{N}_{2}$ fixation can be considerably lower than the stoichiometric value of three. Lab-incubations under increased moisture and temperature conditions led to a strong increase in asymbiotic BNF. Previous estimates of asymbiotic BNF may thus, be substantially biased. Our study showed that asymbiotic BNF is of minor importance for intensively managed agricultural ecosystems. However, it may be an important pathway for BNF on a global scale that may substantially contribute to the amount of $\mathrm{N}$ fixed in the absence of human activities. 


\section{GENERAL INTRODUCTION}

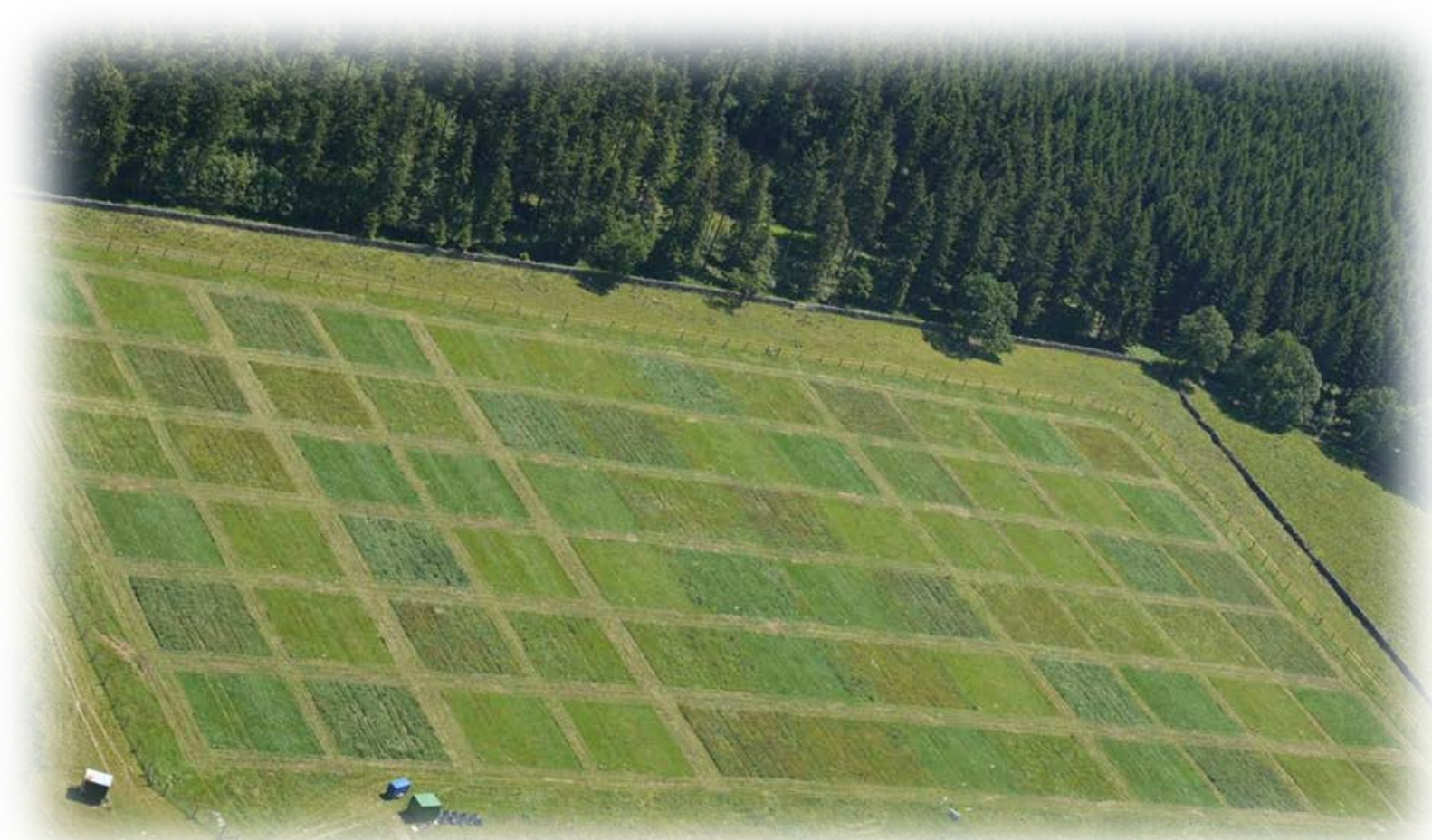

(C) Laura Rose 


\subsection{Anthropogenic alterations of the nitrogen cycle}

Nitrogen $(\mathrm{N})$ is one of the most important plant nutrients that limits net primary productivity in most ecosystems (Vitousek and Horwarth 1991). Molecular dinitrogen $\left(\mathrm{N}_{2}\right)$ is the most abundant gas in the atmosphere with a proportion of $78 \%$. This unreactive $\mathrm{N}$, however, is not available for most organisms (Vitousek et al. 1997). In the absence of human influences, $\mathrm{N}_{2}$ can be transformed into reactive forms and consequently introduced to the plant-soil system through biological $\mathrm{N}$ fixation (BNF) and N fixation by lightnings (Cleveland et al. 1999). Human activity, however, had a huge impact on the global $\mathrm{N}$ cycle in the last decades. The anthropogenic production of reactive $\mathrm{N}$ has more than doubled $\mathrm{N}$ fixation and is considered to be the most important anthropogenic change to the $\mathrm{N}$ cycle (Vitousek et al. 1997). The growing global population has led to agricultural intensification and an increase in the production of synthetic $\mathrm{N}$ fertilizers (Haber Bosch process) - a trend expected to continue in the future (Galloway et al. 2008).

$\mathrm{N}$ fertilizers have remarkably contributed to an increasing food production in the last decades (Smil 2001). However, an intensive use of synthetic $\mathrm{N}$ fertilizers goes along with negative environmental impacts that cannot be disregarded. For instance, in croplands only $50 \%$ of all anthropogenic $\mathrm{N}$ inputs worldwide are taken up by harvested plants and their residues (Smil 1999). Consequently, large proportions can be lost from the plant-soil system through nitrate $\left(\mathrm{NO}_{3}{ }^{-}\right)$ leaching or gaseous emissions (e.g. nitrous oxide $\left(\mathrm{N}_{2} \mathrm{O}\right)$ ). $\mathrm{NO}_{3}{ }^{-}$can be a threat for groundwater quality and cause Methemoglobinemia when it is taken up with drinking water (Di and Cameron 2002, Schlesinger 2009). Impacts on human health other than that - including reproductive risks and cancer - are being discussed as well (Ward et al. 2005). Moreover, $\mathrm{NO}_{3}{ }^{-}$can contribute to the eutrophication of surface water bodies (Di and Cameron 2002). The European Union (EU), through directive 91/676/EEC, set the threshold of nitrate concentration in groundwater at $50 \mathrm{mg} \mathrm{NO}_{3}{ }^{-} \mathrm{L}^{-1}$ (European Economic Community 1991). The European Commission reported that $15 \%$ of the EU groundwater monitoring stations found concentrations above this threshold between 2004 and 2007 (European Union 2010). On the other hand, $\mathrm{N}_{2} \mathrm{O}$ is an important greenhouse gas. Its global warming potential is 298 times higher than that of carbon dioxide $\left(\mathrm{CO}_{2}\right)$ (IPCC 2007), and it contributes to the depletion of stratospheric ozone (Di and Cameron 2002, Schlesinger 2009). Atmospheric concentrations of $\mathrm{N}_{2} \mathrm{O}$ increased from 270 parts per billion (ppb) in pre-industrial times to $319 \mathrm{ppb}$ in 2005 (IPCC 2007). Minimizing these $\mathrm{N}$ losses to the environment while maintaining soil quality and high yields is one of the most important challenges in agriculture. This can be achieved through 1) an efficient retention of soil available $\mathrm{N}$ in the plant soil system and 2) a high $\mathrm{N}$ response efficiency (NRE; i.e. a high plant biomass production per unit of plant-available $\mathrm{N}$ ). $\mathrm{NRE}$ is the key link between agricultural management and biogeochemical $\mathrm{N}$ cycling. It is a measure for ecosystem functioning that integrates productivity and $\mathrm{N}$ retention (Hiremath and Ewel 
2001). It accounts for the efficiency of plant-N-uptake from the soil and biomass production per unit of $\mathrm{N}$ once it is taken up by plants (Bridgham et al. 1995). Since a high NRE reflects an efficient $\mathrm{N}$ uptake and thus a high retention of $\mathrm{N}$ in plants, it is negatively correlated with $\mathrm{N}$ losses. In contrast to the sole consideration of $\mathrm{N}$ losses as absolute values, $\mathrm{N}$ retention efficiency relates $\mathrm{N}$ losses to the amount of $\mathrm{N}$ that is actively cycling in the soil and integrates both soil fertility and $\mathrm{N}$ losses. Previously used indices that describe this ecosystem property (Aber et al. 1998), however, only account for “external” $\mathrm{N}$ inputs (i.e. fertilization and $\mathrm{N}$ deposition) and do not consider $\mathrm{N}$ that is made available by mineralization of organic matter - the primary source of plant biomass $\mathrm{N}$ (Mulvaney et al. 2009) crucial to biomass production.

The anthropogenic increase in the creation of reactive $\mathrm{N}$ has been reviewed extensively (e.g. Galloway et al. 2008). The comparison between anthropogenic N sources and BNF (the most important process creating reactive $\mathrm{N}$ in the absence of humans) is, however, problematic. Existing data on BNF are incomplete and spatially unresolved. It is also unclear how BNF has changed from pre-industrial times to today (where it may be influenced by changes in agricultural management or $\mathrm{N}$ deposition). This makes it difficult to estimate the degree of human influences and restricts the ability to predict future changes to the $\mathrm{N}$ cycle (Cleveland et al. 1999, Reed et al. 2011). Consequently further research on BNF rates in managed and natural ecosystems is necessary (Cleveland et al. 1999, Reed et al. 2011). Especially for ecosystems other than crop-production systems, knowledge about the magnitude as well as the ecological controls of BNF are sparse (Vitousek et al. 1997). While symbiotic BNF is the major pathway for BNF in most ecosystems, asymbiotic BNF may be an important $\mathrm{N}$ source in ecosystems where legumes are not abundant. Existing data suggests that asymbiotic BNF may be important in temperate grasslands. However, estimates on asymbiotic BNF in temperate grasslands are variable (Cleveland et al. 1999, Reed et al. 2011) and most of the few available studies these estimates are based on have methodical shortcomings.

\subsection{Temperate grasslands-management and consequences for the $\mathrm{N}$ cycle}

Grasslands cover between 20 and 40\% of the earth's land area (FAO 2008). European grasslands have been subject to agricultural intensification (i.e. increased use of $\mathrm{N}$ fertilizers and increased mowing frequency) in the last decades (Isselstein et al. 2005). In particular, the increase in the use of $\mathrm{N}$ fertilizers made grasslands important sources for $\mathrm{NO}_{3}{ }^{-}$leaching and $\mathrm{N}_{2} \mathrm{O}$ emissions (Rees and Ball 2010). In contrast, decreasing $\mathrm{N}_{2} \mathrm{O}$ emissions following mowing have been reported (Niklaus et al. 2001) and can be attributed to higher plant $\mathrm{N}$ uptake and productivity (Kammann et al. 1998, Ferraro and Oesterheld 2002). Besides these direct effects, grassland management practices may also indirectly affect $\mathrm{N}$ losses through changes in sward compositions and biodiversity. Agricultural 
intensification has led to a dramatic decrease in grassland biodiversity (e.g. Isselstein et al. 2005, Tscharntke et al. 2005). These biodiversity losses may have profound consequences for ecosystem functioning. For example, decreasing productivity with decreasing biodiversity as a consequence of complementary and more efficient resource use in diverse plant communities has been reported in several grassland studies (e.g. Tilman et al. 1996, Hector et al. 1999, Weigelt et al. 2009). Interspecific differences in rooting depths, preferred forms of $\mathrm{N}$ taken up, and phenology in diverse plant communities may be the underlying mechanisms (e.g. Hooper and Vitousek 1998). Accordingly, increases in soil mineral $\mathrm{N}$ concentrations caused by decreasing plant diversity have been demonstrated (e.g. Ewel et al. 1991, Tilman et al. 1996, Niklaus et al. 2001). Interpretation of soil mineral $\mathrm{N}$ concentrations in terms of $\mathrm{N}$ losses are, however, restricted (Scherer-Lorenzen et al. 2003) and there are only few studies that directly quantified $\mathrm{N}$ losses as a function of plant-diversity (Hooper and Vitousek 1998, Scherer-Lorenzen et al. 2003). In addition, most of the studies investigating the effect of grassland biodiversity on productivity and $\mathrm{N}$ losses have been carried out in artificial and intensively weeded grassland communities making it difficult to compare with permanent managed grasslands (Caliman et al. 2010, Wrage et al. 2011). No studies have been conducted on the effects of agricultural management and biodiversity on $\mathrm{N}$ response efficiency and $\mathrm{N}$ retention efficiency in temperate permanent managed grasslands.

Asymbiotic BNF may also be affected by grassland management practices. Negative effects of $\mathrm{N}$ fertilization have been reported by several studies (e.g. Vlassak et al. 1973) and are related to an inhibition of nitrogenase, the enzyme complex that catalyzes $\mathrm{BNF}-$ by ammonium $\left(\mathrm{NH}_{4}{ }^{+}\right)$and nitrate $\left(\mathrm{NO}_{3}{ }^{-}\right.$) (Yoch and Whiting 1986, Bottomley and Myrold 2007). Besides that, positive effects of phosphorus (P) fertilization have been reported and attributed to high ATP requirements of the BNF process (e.g. Reed et al. 2007). However, the roles of the elements $\mathrm{N}$ and $\mathrm{P}$ as factors controlling asymbiotic BNF are still under discussion (Reed et al. 2011). Due to their contradicting effect, N:P ratios maybe better predictors for asymbiotic BNF than absolute abundances of $\mathrm{N}$ or $\mathrm{P}$ (Eisele et al. 1989). So far, no study testing the effect of combined fertilization with $\mathrm{N}$ and $\mathrm{P}$ under field-conditions is available. The effect of mowing on asymbiotic BNF in temperate grasslands has also not yet been tested. Plant-defoliation, which occurs during mowing, can increase rhizodeposition (Holland et al. 1996) and the amount of available carbon (C) for soil microorganisms. Since asymbiotic heterotrophic BNF is an energy-intensive process, it may be stimulated by such C inputs (Bürgmann et al. 2005). 


\subsection{The GRASSMAN project}

The interdisciplinary grassland management project „GRASSMAN“ was established in 2008 on a permanent grassland site in the Solling uplands, Lower Saxony, Germany (514'53"N, 9³2'42"E) in an elevation of $490 \mathrm{~m}$ above sea level (Fig. 1). Presently this site belongs to the experimental farm Relliehausen. Mean annual temperature and precipitation are $6.9^{\circ} \mathrm{C}$ and $1028 \mathrm{~mm}$, respectively (Deutscher Wetterdienst 1961 - 1990). Prior to the experiment, the vegetation was clasified as a montane, semi-moist Lolio-Cynosuretum (Petersen et al. 2011). The dominating soil type - a haplic Cambisol (IUSS Working Group WRB 2006) with a loamy silt texture - has developed on a loess layer overlaying the middle Buntsandstein formation. The site has been used for hay-making and cattle grazing since at least 100 years (Geological Map of Prussia (based on the topographic inventory 1896), topographic maps of Sievershausen and Neuhaus/Solling 1924, 1956 and 1974)). In the last 50 years, the site received moderate fertilizer applications (80 $\left.\mathrm{kg} \mathrm{N} \mathrm{ha}^{-1} \mathrm{yr}^{-1}\right)$, occasional lime applications and overseeding with high value forage species (farm records of Relliehausen since 1966). Fertilization stopped two years before the experiment. In 2008, the experiment started as a three-factorial design with the factors fertilization, mowing frequency and sward composition. Since then, half of the plots were fertilized with $180 \mathrm{~kg} \mathrm{~N} \mathrm{ha}^{-1} \mathrm{yr}^{-1}, 30 \mathrm{~kg} \mathrm{P} \mathrm{ha}^{-1} \mathrm{yr}^{-1}$ and $100 \mathrm{~kg} \mathrm{~K}$ $\mathrm{ha}^{-1} \mathrm{yr}^{-1}$. Mineral $\mathrm{N}$ fertilization (calcium ammonium nitrate $\mathrm{N} 27$, ICL fertilizers Deutschland GmbH, Ludwigshafen, Germany) was applied in two equal applications per year (April and May/June). P and K fertilizer was applied once per year in June (2009: Thomaskali ${ }^{\circledR}(\mathrm{K}+\mathrm{S}$ KALI GmbH, Kassel, Germany); 2010-2012: PK+ Dünger (ICL Fertilizers Deutschland GmbH, Ludwigshafen, Germany)). Two mowing frequencies (once and three times per year) were established. Mowing was conducted in July for plots cut once and in May, July and September for plots cut three times per year with a Haldrup (C) forage combine harvester (cutting height: $7 \mathrm{~cm}$ ). Three sward compositions were established by applying herbicides. A herbicide mixture against dicotyledons (Starane ${ }^{\circledR}$ (active ingredients: Flouoxypyr and Triclopyr)) and Duplosan KV (active ingredient: Mecoprop-P $\left.{ }^{\circledR}\right)$ ) resulted in a sward with enhanced proportions of monocotyledons and a significantly lower number of species (12-13 species; 91-93\% grasses, 7-9\% herbs; hereafter referred to as monocot-enhanced) and a herbicide mixture against monocotyledons (Select 240 EC® by Stähler (active ingredient: Clethodim)) resulted in a sward with enhanced proportions of dicotyledons (17 species; $40-47 \%$ grasses, $49-53 \%$ herbs, $4-9 \%$ legumes, hereafter referred to as dicot-enhanced ) relative to the control sward (16-18 species; $68-76 \%$ grasses, $21-31 \%$ herbs, $1-4 \%$ legumes) (Petersen et al. 2011). The experiment was set up as a full-factorial design. The combination of the three treatment factors (fertilization, mowing, sward composition) resulted in twelve different treatment combinations. Each treatment combination was replicated six times. The resulting 72 plots (15 m x 15 m each) were arranged in a Latin Rectangle (Fig. 2). 


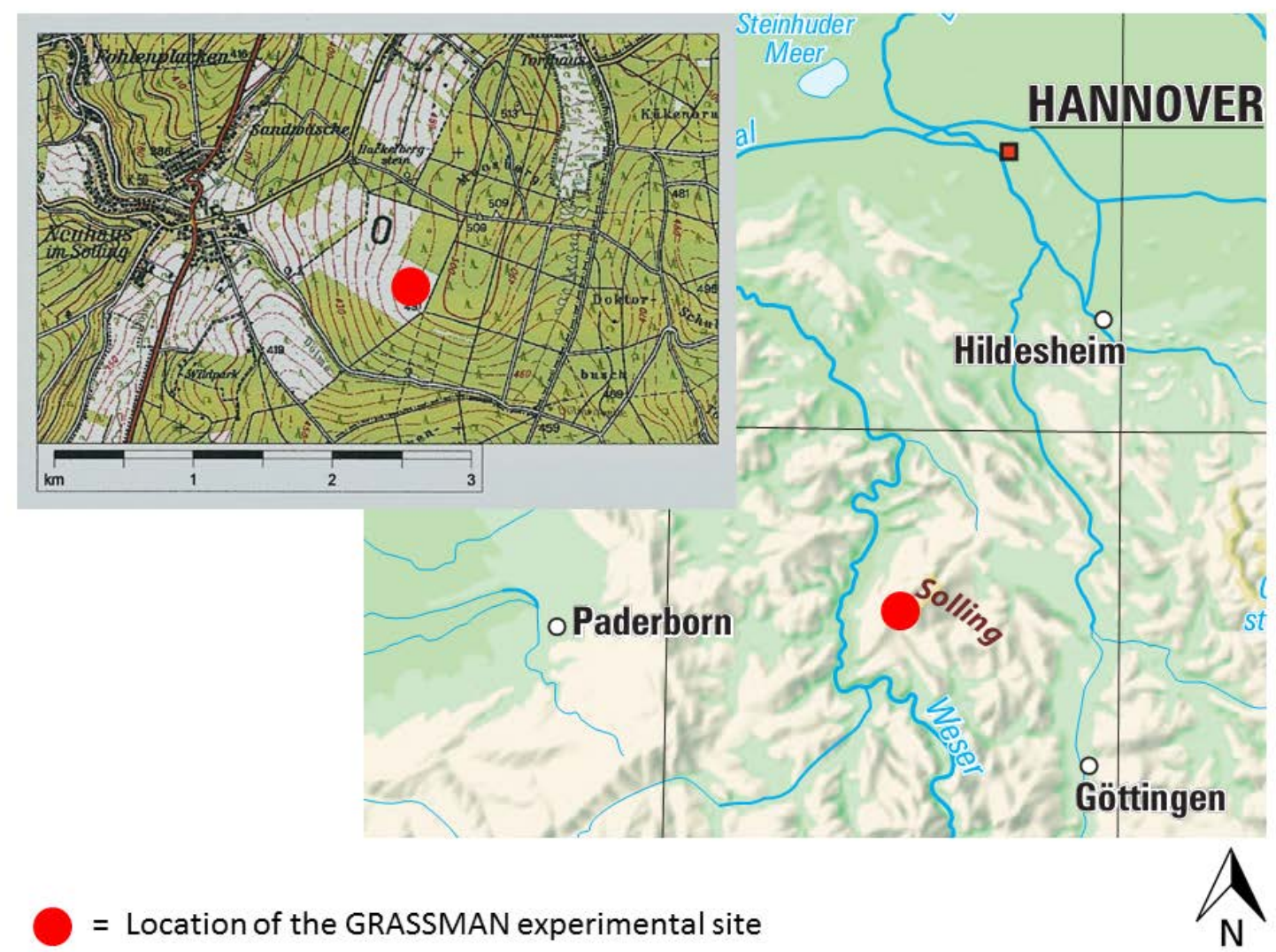

Figure 1: Location of the GRASSMAN experimental site in the Solling uplands, Lower Saxony, Germany. Maps: Amtliche topographische Karte 1:50.000 (C Landesvermessungsamt NRW, Bundesamt für Kartographie und Geodäsie 2000); Orohydrographische Karte 1:2.500.000 (C Bundesamt für Kartographie und Geodäsie).

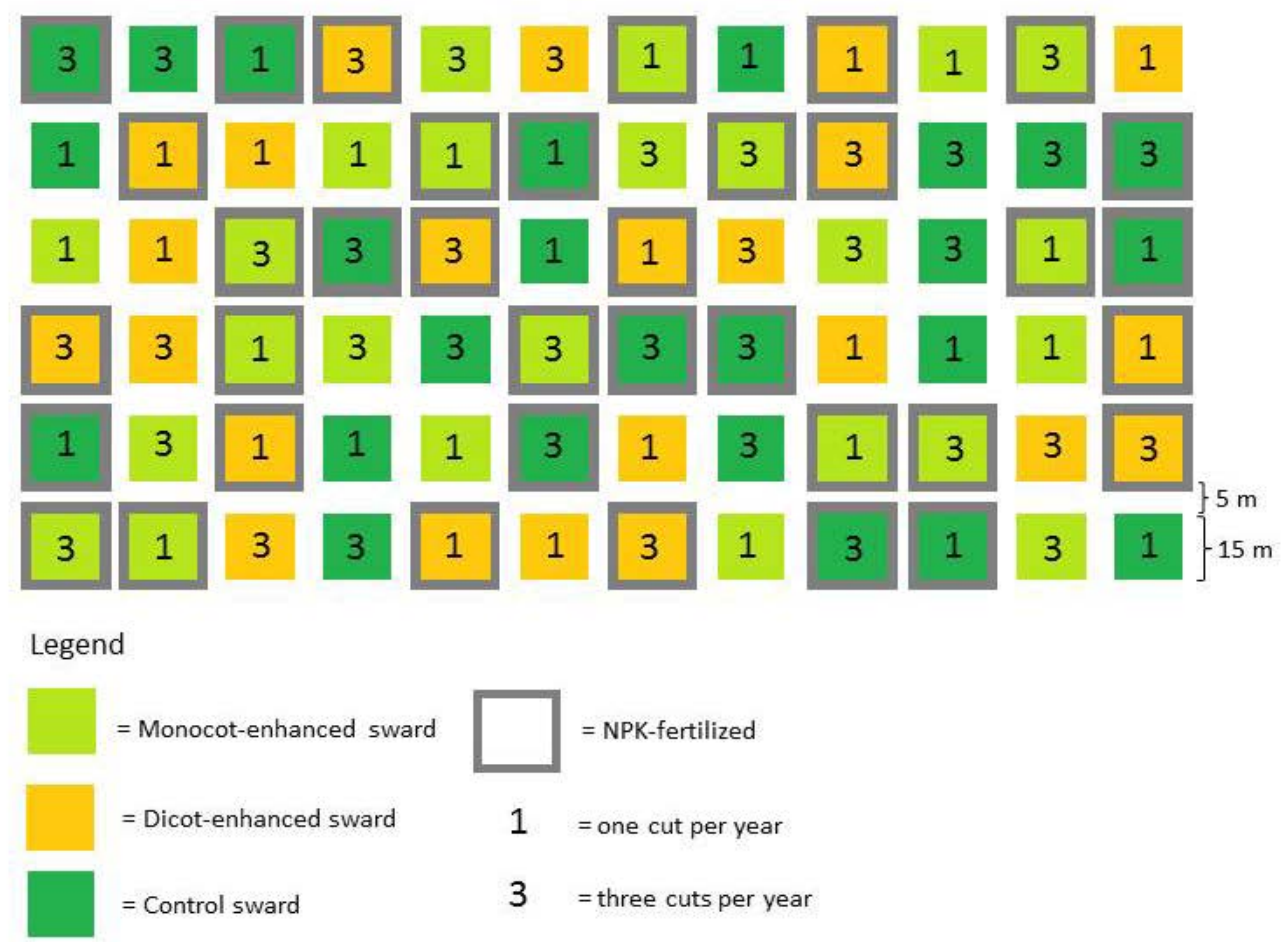

Figure 2: Experimental design of the GRASSMAN experiment. 


\subsection{Objectives and hypotheses}

The aim of this study was to test the influence of grassland management practices (fertilization and mowing frequency) and plant functional group composition on NRE, $\mathrm{N}$ losses, $\mathrm{N}$ retention efficiency and asymbiotic BNF in a temperate managed grassland site. We aimed to develop a new index that describes $\mathrm{N}$ retention efficiency as an ecosystem property and relates $\mathrm{N}$ losses to the amount of all $\mathrm{N}$ actively cycling in the soil.

The following hypotheses were tested in three different studies:

Study I: Nitrogen response efficiency of a managed and phytodiverse temperate grassland

Hypotheses:

- $\quad \mathrm{N}$ fertilization decreases NRE

- frequent mowing increases NRE

- NRE is highest in swards with even proportions of dicotyledons and monocotyledons and high species richness

\section{Study II: Nitrogen retention efficiency and nitrogen losses of a managed and phytodiverse} temperate grassland

Hypotheses:

- $\quad \mathrm{N}$ fertilization decreases $\mathrm{N}$ retention efficiency (and consequently increases $\mathrm{N}$ losses)

- frequent mowing decreases $\mathrm{N}$ losses

- $\quad \mathrm{N}$ retention efficiency is highest in swards with even proportions of dicotyledons and monocotyledons and high species richness

Study III: Asymbiotic biological nitrogen fixation in a temperate grassland under different fertilization and mowing treatments

Hypotheses:

- combined fertilization with $\mathrm{N}$ and P decreases asymbiotic BNF

- frequent mowing increases asymbiotic BNF 


\section{References}

Aber J, McDowell W, Nadelhoffer K, et al. (1998): Nitrogen saturation in temperate forest ecosystems. Bioscience 48: 921-934.

Bottomley PJ and Myrold DD (2007): Biological nitrogen fixation: The return of $\mathrm{N}$ to the soil. In: Paul EA(ed) Soil Microbiology, Ecology, and Biochemistry, 3rd Edition. Academic Press, Burlington, MA, pp. 365-387.

Bridgham SD, Pastor J, Mc Claugherty CA, and Richardson CJ (1995): Nutrient-use efficiency - a litterfall index, a model, and a test along a nutrient-availability gradient in North-Carolina peatlands. The American Naturalist 145: 1-21.

Bürgmann H, Meier S, Bunge M, Widmer F, and Zeyer J (2005): Effects of model root exudates on structure and activity of a soil diazotroph community. Environmental Microbiology 7: 1711-1724.

Caliman A, Pires A, Esteves F, et al. (2010): The prominence of and biases in biodiversity and ecosystem functioning research. Biodiversity and Conservation 19: 651-664.

Cleveland CC, Townsend, AR, Schimel DS, et al. (1999): Global patterns of terrestrial biological nitrogen $\left(\mathrm{N}_{2}\right)$ fixation in natural ecosystems. Global Biogeochemical Cycles 13: 623-645.

Di HJ and Cameron KC (2002): Nitrate leaching in temperate agroecosystems: sources, factors and mitigating strategies. Nutrient Cycling in Agroecosystems 64: 237-256.

Eisele KA, Schimel DS, Kapustka LA, and Parton WJ (1989): Effects of available P and N:P ratios on non-symbiotic dinitrogen fixation in tallgrass prairie soils. Oecologia 79: 471-474.

European Economic Community (1991): Council Directive 19/676/EEC of 12 December, 1991 concerning the protection of waters against pollution caused by nitrates from agricultural sources. Official Journal L (375), 1.

European Union (2010): The EU nitrates directive. http://ec.europa.eu/environment/pubs/pdf/factsheets/nitrates.pdf.

Ewel JJ, Mazzarino MJ, and Berish CW (1991): Tropical soil fertility changes under monocultures and successional communities of different structure. Ecology Applications 1: 289-302.

FAO (2008): Are grasslands under threat? Brief analysis of FAO statistical data on pasture and fodder crops. http://www.fao.org/ag/agp/agpc/doc/grass_stats/grass-stats.htm.

Ferraro DO and Oesterheld M (2002): Effect of defoliation on grass growth. A quantitative review. Oikos 98:125-133.

Galloway JN, Townsend AR, Erisman JW, et al. (2008): Transformation of the nitrogen cycle: Recent trends, questions, and potential solutions. Science 320: 889-892.

Hector A, Schmid B, Beierkuhnlein C, Caldeira MC, et al. (1999): Plant diversity and productivity experiments in European grasslands. Science 286: 1123-1127.

Hiremath AJ and Ewel JJ (2001): Ecosystem nutrient use efficiency, productivity, and nutrient accrual in model tropical communities. Ecosystems 4: 669-682.

Holland JN, Cheng WX, and Crossley DA (1996): Herbivore-induced changes in plant carbon allocation: Assessment of below-ground C fluxes using carbon-14. Oecologia 107: 87-94.

Hooper DU and Vitousek PM (1998): Effects of plant composition and diversity on nutrient cycling. Ecological Monographs 68: 121-149.

IUSS working group WRB (2006): World reference base for soil resources 2006. World soil resources reports No. 130. FAO, Rome.

IPCC (2007): Intergovernmental Panel on Climate Change Report. Cambridge University Press, Cambridge.

Isselstein J, Jeangros B., and Pavlu, V (2005): Agronomic aspects of biodiversity targeted management of temperate grasslands in Europe - a review. Agronomy Research 3: 139-151. 
Kammann C, Grunhage L, Muller C, Jacobi S, and Jager HJ (1998): Seasonal variability and mitigation options for $\mathrm{N}_{2} \mathrm{O}$ emissions from differently managed grasslands. Journal of Environmental Pollution 102:179-186.

Mulvaney RL, Khan SA, and Ellsworth TR (2009): Synthetic nitrogen fertilizers deplete soil nitrogen: a global dilemma for sustainable cereal production. Journal of Environmental Quality 38: 2295-2314.

Niklaus PA, Kandeler E, Leadley PW, Schmid B, Tscherko D, and Korner C (2001): A link between plant diversity, elevated $\mathrm{CO}_{2}$ and soil nitrate. Oecologia 127: 540-548.

Petersen U, Wrage N, Köhler L, Leuschner C, and Isselstein J (2011): Manipulating the species composition of permanent grass-lands - a new approach to biodiversity experiments. Basic and Applied Ecology: doi:10.1016/j.baae.2011.10.003

Reed SC, Seastedt TR, Mann CM, Suding KN, Townsend AR, and Cherwin KL (2007): Phosphorus fertilization stimulates nitrogen fixation and increases inorganic nitrogen concentrations in a restored prairie. Applied Soil Ecology 36: 238-242.

Reed SC, Cleveland CC, and Townsend AR (2011): Functional ecology of free-living nitrogen fixation: a contemporary perspective. Annual Review of Ecology, Evolution, and Systematics 42: 489-512.

Rees RM and Ball BC (2010): Soils and nitrous oxide research. Soil Use and Management 26: 193-195.

Scherer-Lorenzen M, Palmborg C, Prinz A, and Schulze ED (2003): The role of plant diversity and composition for nitrate leaching in grasslands. Ecology 84: 1539-1552.

Schlesinger WH (2009): On the fate of anthropogenic nitrogen. Proceedings of the National Academy of Sciences 106 : 203-208.

Smil V (1999): Nitrogen in crop production: An account of global flows. Global Biogeochemical Cycles 13:647-662.

Smil V (2001): Enriching the earth: Fritz Haber, Carl Bosch, and the transformation of world food production. The MIT Press, Cambridge, MS, London.

Tilman D, Wedin D, and Knops J (1996): Productivity and sustainability influenced by biodiversity in grassland ecosystems. Nature 379: 718-720.

Tscharntke T, Klein AM, Kruess A, Steffan-Dewenter I, and Thies C (2005): Landscape perspectives on agricultural intensification and biodiversity - ecosystem service management. Ecology Letters 8: 857-874.

Vitousek PM and Howarth RW (1991): Nitrogen limitation on land and in the sea - how can it occur? Biogeochemistry 13: 87-115.

Vitousek PM, Aber JD, Howarth RW, et al. (1997): Human alteration of the global nitrogen cycle: sources and consequences. Ecological Applications 7: 737-50.

Vlassak K, Paul EA, and Harris RE (1973): Assessment of biological nitrogen fixation in grassland and associated sites. Plant and Soil 38: 637-649.

Ward MH, deKok TM, Levallois P, et al. (2005): Workgroup Report: Drinking-water nitrate and health—recent findings and research needs. Environ Health Perspectives 113 (11): 1607-1614.

Weigelt A, Weisser WW, Buchmann N, and Scherer-Lorenzen M (2009): Biodiversity for multifunctional grasslands: equal productivity in high-diversity low-input and low-diversity high-input systems. Biogeosciences 6:1695-1706.

Wrage N, Strodthoff J, Cuchillo M H, Isselstein J, and Kayser M (2011): Phytodiversity of temperate permanent grasslands: Ecosystem services for agriculture and livestock management for diversity conservation. Biodiversity and Conservation. DOI : 10.1007/s10531-011-0145-6, 3317-3339.

Yoch DC and Whiting GJ (1986): Evidence for $\mathrm{NH}_{4}{ }^{+}$switch-off regulation of nitrogenase activity by bacteria in salt marsh sediments and roots of the grass Spartina alterniflora. Applied and Environmental Microbiology: 143149. 


\title{
2 NITROGEN RESPONSE EFFICIENCY OF A MANAGED AND PHYTODIVERSE TEMPERATE GRASSLAND
}

\author{
Andreas Keuter*, Ina Hoeft*, Edzo Veldkamp, Marife D. Corre \\ * these authors contributed equally to this work
}

Published 2012 in Plant and Soil (DOI 10.1007/s11104-0 12-1344-y) 


\section{Abstract}

Aims

Our goal was to assess how management and sward functional diversity affect nitrogen response efficiency (NRE), the ratio of plant biomass production to supply of available nitrogen (N) in temperate grassland.

Methods

A three-factorial design was employed: three sward compositions, two mowing frequencies, and two fertilization treatments.

\section{Results}

NRE was largely influenced by fertilization followed by mowing frequency and sward composition. NRE was larger in unfertilized than fertilized plots, in plots cut thrice than plots cut once per year, and in control swards than in monocot- or dicot-enhanced swards. Fertilization decreased NRE through decreases in both $\mathrm{N}$ uptake efficiency (plant $\mathrm{N}$ uptake per supply of available $\mathrm{N}$ ) and $\mathrm{N}$ use efficiency (NUE, biomass produced per plant $\mathrm{N}$ uptake) whereas mowing frequency and sward composition affected NRE through $\mathrm{N}$ uptake efficiency rather than NUE. The largest NRE in the control sward with $70 \%$ monocots and $30 \%$ dicots attests that these proportions of functional groups were best adapted in this grassland ecosystem.

\section{Conclusions}

Optimum NRE may not be a target of most farmers, but it is an appropriate tool to evaluate the consequences of grassland management practices, which farmers may employ to maximize profit, on environmental quality. 


\subsection{Introduction}

Nutrient response efficiency, the amount of biomass produced per unit of plant-available nutrients (Pastor and Bridgham 1999), is a measure of ecosystem functioning that integrates productivity and the retention of nutrients (Hiremath and Ewel 2001). In terrestrial ecosystems where nitrogen (N) is limiting net primary productivity (Vitousek and Howarth 1991), the efficient use of available N may give communities a competitive advantage over communities that are less efficient in using $\mathrm{N}$ (Bridgham et al. 1995). There is no common agreement about the definitions of nitrogen response efficiency (NRE) and nitrogen use efficiency (NUE) in literature (Xu et al. 2012; Aerts 1990; Vitousek 1982). In our study, NRE is calculated as the product of $\mathrm{N}$ uptake efficiency (defined as plant $\mathrm{N}$ concentration $\mathrm{x}$ plant biomass $\div$ soil available $\mathrm{N}$ ) and NUE ( defined as plant biomass $\div$ plant $\mathrm{N}$ concentration $\mathrm{x}$ plant biomass), two indices that are commonly used to evaluate the role of $\mathrm{N}$ in ecosystem productivity (Pastor and Bridgham 1999). However, both indices give an incomplete picture of how $\mathrm{N}$ availability affects biomass production. A large NUE does not necessarily reflect a large productivity because NUE can increase or decrease if the plant $\mathrm{N}$ concentration changes even if plant biomass stays the same. NUE is also often not well correlated with soil N availability (Iversen et al. 2010). Similarly, N uptake efficiency does not directly indicate productivity as it is influenced by changes in plant $\mathrm{N}$ concentration. In contrast, NRE is an index that reflects the ability of plants to acquire $\mathrm{N}$ from the soil and to use it for biomass production once it is taken up (Bridgham et al. 1995), and thus it is a better index if biomass production is the main goal (as is the case in most temperate grasslands). Since a large NRE indicates a large biomass production per unit of soil available $\mathrm{N}$ and thus a large $\mathrm{N}$ retention in plants, it is inversely correlated with $\mathrm{N}$ lost, e.g. through nitrate $\left(\mathrm{NO}_{3}{ }^{-}\right)$leaching and gaseous $\mathrm{N}$ emissions. A large NRE may thus contribute to the reduction of reactive $\mathrm{N}$ in the soil, which affects water and air pollution as well as the emission of greenhouse gases (Dobermann 2005).

Pastor and Bridgham (1999) developed a general model of NRE showing maximum efficiency at intermediate levels of $\mathrm{N}$ availability. In their model, productivity $\left(\mathrm{P}_{\mathrm{N} \text { supply }}\right)$ at a given level of available $\mathrm{N}$ (i.e. $\mathrm{N}$ supply in the environment) is defined as:

$\mathrm{P}_{\mathrm{N} \text { supply }}=\mathrm{N}$ supply $*(\mathrm{P} \div \mathrm{N}$ supply $)+0$

In this model, NRE is the slope of a line from the origin to a given point of the function that describes the relationship between productivity and N supply (Pastor and Bridgham 1999). This implies that NRE changes with $\mathrm{N}$ supply and depends on the shape of the function in Eq. 1. If the relationship between productivity and $\mathrm{N}$ supply is linear, NRE is constant across a gradient of $\mathrm{N}$ supply. However, a linear relationship over a wide range of $\mathrm{N}$ supply is unlikely given the observation that no further increase in productivity occurs at high levels of $\mathrm{N}$ availability (Pastor and Bridgham 1999). Studies that investigated the relationships between NRE and soil $\mathrm{N}$ 
availability found increases in NRE as soil $\mathrm{N}$ availability declined in an experimental plantation of tropical trees (Hiremath and Ewel 2001; Yuan et al. 2006). Bridgham et al. (1995) gave a mathematical proof that nutrient response efficiency has to be unimodal across broad ranges of nutrient supply. However, the unimodal efficiency has not been observed for $\mathrm{N}$ so far and is debatable (Yuan et al. 2006). A monotonic increase of NRE with decreasing soil N availability was observed by Yuan et al. (2006) for Mongolian grassland.

NRE can be influenced by management practices and plant diversity through their effects on $\mathrm{N}$ availability, uptake efficiency and NUE. Management practices commonly employed in grasslands are fertilization and mowing. Fertilization directly influences $\mathrm{N}$ availability. Furthermore, mowing removes available $\mathrm{N}$ from the ecosystem through the mown biomass. In systems with large nutrient availability, mowing may mitigate the negative effects of nutrient enrichment on plant diversity by removing excess nutrients (Ellenberg and Leuschner 2010; Pykälä 2000). Mowing can also lead to a denser root system in the top soil by increasing the root-to-shootratio and thus causing a more effective plant $\mathrm{N}$ uptake (Kammann et al. 1998; Mooney and Winner 1991). In contrast, an increase in allocation of resources to the shoots (Guitian and Bardgett 2000) as well as a decrease in root biomass following defoliation have been reported by other studies (Dawson et al. 2000; Holland and Detling 1990). Mikola et al. (2009) also reported that even for grazed grasslands defoliation is the most important mechanism explaining grazing effects on plant attributes while excreta return play only a minor role. To date, there are no published studies on how $\mathrm{N}$ fertilization, mowing frequency and their interactions affect NRE of temperate grasslands, and thus the present study is the first to report such pattern.

Apart from direct effects, management practices may also affect NRE through a change in species composition of the sward. In the past six decades, European grasslands have undergone many changes in management (e.g. increased fertilizer input and mowing frequency, or abandonment from agricultural use) that had profound consequences for biodiversity (Isselstein et al. 2005). The impact of plant diversity on nutrient uptake, productivity and NRE has been subject of several studies. Hiremath and Ewel (2001) reported an increase in N uptake efficiency with increase in life-form diversity for a tropical tree plantation. Several studies showed that more diverse grasslands were more productive (e.g. Hector et al. 1999; Tilman et al. 1996; Weigelt et al. 2009) with an increased nutrient retention from more diverse grassland ecosystems (Tilman et al. 1996). Furthermore, van Ruijven and Berendse (2005) observed an increase in productivity and NUE with increasing species richness. These studies, however, were conducted in experimentallyestablished plots that were weeded intensively, or in microcosms, making them difficult to compare with results from permanent grasslands where no clear effect of biodiversity on productivity has yet been demonstrated (Wrage et al. 2011). This may be due to the larger species richness in permanent 
grassland compared to many studies where diversity effects were largest at species richness levels smaller than five species (Wrage et al. 2011). Although Flombaum and Sala (2008) reported a larger effect of plant biodiversity on productivity in a natural grassland ecosystem compared to artificial ecosystems, their study only included a biodiversity gradient of one to six species, which is still considerably lower than managed, temperate grasslands with 10 to 60 plant species (Wrage et al. 2011). So far no studies on the impact of management practices, sward composition and their interactions on NRE in agriculturally-managed, permanent grassland have been published. As the efficiency with which grasslands use available $\mathrm{N}$ for biomass production is the key link between management and biogeochemical $\mathrm{N}$ cycling, our goal was to evaluate how NRE changes as a function of different management practices and sward compositions in an agriculturally-managed, permanent grassland site. We measured NRE of a grassland site that was managed according to local practices in the Solling Mountains (Lower Saxony, Germany). Here, we only considered the harvestable, aboveground biomass because our study focuses on agricultural management practices. Plant functional group diversity was manipulated by herbicide treatments, resulting in dicotenhanced swards with nearly equal proportions of dicots and monocots, control swards with $\sim 70 \%$ monocots and $\sim 30 \%$ dicots, and monocot-enhanced swards with $\sim 90 \%$ monocots and $\sim 10 \%$ dicots. Species richness was significantly smaller in the monocot-enhanced swards compared to the control swards (Petersen et al. 2011). N supply (used as the measure of $\mathrm{N}$ availability in the environment) was defined as the sum of soil net $\mathrm{N}$ mineralization rates during the growing season, $\mathrm{N}$ deposition from bulk precipitation, and fertilizer addition rates. We tested the following hypotheses: 1) unfertilized plots have larger NRE than fertilized plots, 2) plots with high mowing frequency have larger NRE than plots with low mowing frequency, and 3) NRE increases with increasing number of species (i.e. monocot-enhanced swards (12-13 species) < dicot-enhanced (17 species) and control swards (16-18 species)).

\subsection{Material and methods}

\subsubsection{Study site}

This interdisciplinary research project, grassland management experiment or GRASSMAN, was conducted at the experimental farm of the University of Göttingen on a moderately species-rich grassland in the Solling Mountains in Lower Saxony, Germany (5144'53"N, 9³2'42"E, $490 \mathrm{~m}$ above sea level). This permanent grassland site has traditionally been used as a pasture for hay making or for grazing (Geological Map of Prussia 1910 (based on the topographic inventory of 1896); topographic maps of Sievershausen and Neuhaus/Solling 1924, 1956 and 1974; Braunschweigische Landesaufnahme $18^{\text {th }}$ century). In the last five decades, the study site was managed with moderate fertilization ( $\left.80 \mathrm{~kg} \mathrm{~N} \mathrm{ha}^{-1} \mathrm{yr}^{-1}\right)$, liming, overseeding with high value forage 
species and cattle grazing (farm records of Relliehausen since 1966). Fertilization stopped two years before our experiment started. Vegetation consists of a montane, semi-moist Lolio-Cynosuretum. Mean annual precipitation is $1028 \mathrm{~mm}$ and mean annual temperature is $6.9^{\circ} \mathrm{C}$ (Deutscher Wetterdienst, 1961 - 1990, station Holzminden-Silberborn, $440 \mathrm{~m}$ above sea level). During the study period, mean annual temperature and annual precipitation were $8.4^{\circ} \mathrm{C}$ and $1001 \mathrm{~mm}$ in 2009 and $8.0^{\circ} \mathrm{C}$ and $1110 \mathrm{~mm}$ in 2010. The dominating soil type is a Haplic Cambisol, developed on sediments of loess on the Middle Buntsandstein formation with a loamy silt texture.

\subsubsection{Experimental set up}

The study had a three-factorial design: three sward compositions, two mowing frequencies and two fertilization treatments. In June 2008, we established three sward compositions by applying a herbicide mixture against dicotyledons (Starane ${ }^{\circledR}$ (active ingredients: Fluoroxypyr and Triclopyr) and Duplosan KV (active ingredients: Mecoprop-P®)) resulting in a sward with reduced proportions of herbs and legumes, a herbicide mixture against monocotyledons (Select 240 EC® by Stähler (active ingredients: Clethodim)) resulting in a sward with reduced proportions of grasses, and an untreated control sward. Hereafter, we refer to these sward compositions as monocotenhanced (12-13 species; 91-93\% grasses, 7-9\% herbs and 0\% legumes) and dicot-enhanced (17 species; $40-47 \%$ grasses, $49-53 \%$ herbs and 4-9\% legumes) relative to the control sward (16-18 species; 68-76\% grasses, 21-31\% herbs and 1-4\% legumes) (Petersen et al. 2011). In 2008, all experimental plots were mown, and fertilized plots received $50 \mathrm{~kg} \mathrm{~N} \mathrm{ha}^{-1}$. The experiment started in spring 2009 with two mowing frequencies (once per year in July and thrice per year in May, July and September) as well as two fertilization treatments $\left(180-30-100 \mathrm{~kg} \mathrm{NPK} \mathrm{ha}^{-1} \mathrm{yr}^{-1}\right.$ and no fertilization). The $\mathrm{N}$ fertilizer (calcium ammonium nitrate $\mathrm{N} 27$ ) was split into two equal applications per year (April and May 2009 and April and June 2010) while the combined P and K fertilizer was applied once a year (June 2009 and 2010). The experimental treatments were set up with 6 replicates in a full factorial design (72 plots; $15 \mathrm{~m}$ x $15 \mathrm{~m}$ each) arranged in a Latin rectangle.

\subsubsection{Soil characteristics}

Soil characteristics (Table 1) were determined in spring 2008 (chemical and texture analyses) and summer 2009 (bulk density). At nine sampling points per plot, mineral soils (0.01-0.1 m depth) were sampled, pooled, oven-dried $\left(40^{\circ} \mathrm{C}\right)$ for a week and sieved $(2 \mathrm{~mm})$. Particle size distribution was determined by wet sieving $(>20<630 \mu \mathrm{m})$ and pipette methods $(\leq 20 \mu \mathrm{m})$ after pre-treatment with $30 \% \mathrm{H}_{2} \mathrm{O}_{2}$ and $4 \%$ Na-dithionite-citrate solution to remove organic matter and iron oxides (Schlichting et al. 1995). Soil bulk density was determined by soil core method (Blake and Hartke 
1986). Cation exchange capacity (CEC) was determined using the method of $0.1 \mathrm{M} \mathrm{BaCl}_{2}$ percolation (König and Fortmann 1996) and measuring cations in percolates using Inductively Coupled Plasma - Optical Emission Spectrometry (Optima 3000 XL, Perkin Elmer, Rodgau, Germany). Base saturation was determined as the percentage exchangeable base cations of the CEC. Soil pH was measured from soil:water suspension (ratio of 1:2). Total C and N concentrations were determined from ground soils using a CN elemental analyzer (Elementar Vario EL III, Hanau, Germany).

Table 1: Soil characteristics in the Ah horizon (0.01-0.1 m) of a Haplic Cambisol of a grassland site in the Solling Mountains, Germany.

\begin{tabular}{lccc}
\hline Physical and chemical ${ }^{*}$ properties & Mean & SE & 18 \\
\hline Sand (\%) & 21.62 & 1.2 & 18 \\
Silt (\%) & 66.53 & 0.8 & 18 \\
Clay (\%) & 11.85 & 0.01 & 72 \\
Bulk density $\left(\mathrm{g} \mathrm{cm}^{-3}\right)$ & 0.79 & 5.2 & 72 \\
\hline Cation exchange capacity $\left(\mathrm{mmol}_{\mathrm{c}} \mathrm{kg}^{-1}\right)$ & 169.00 & 1.4 \\
Base saturation (\%) & 37.18 & 72 \\
pH (1:2 $\left.\mathrm{H}_{2} \mathrm{O}\right)$ & 5.34 & 0.03 & 72 \\
Carbon : Nitrogen ratio & 12.60 & 0.04 & 72
\end{tabular}

* Soil chemical data were provided by the Department of Plant Ecology, University of Göttingen 


\subsubsection{Biomass yield and plant $\mathrm{N}$ uptake}

Data of aboveground biomass was reported by From et al. (2011) (see Appendix 1). The grassland was mown in mid-July for plots with one cut $\mathrm{yr}^{-1}$ and in mid-May, mid-July and end of September of each year for plots with three cuts $\mathrm{yr}^{-1}$. A Haldrup (C) forage combine harvester was used with a cutting height of $7 \mathrm{~cm}$. Dry mass of the biomass was determined by oven-drying at $60{ }^{\circ} \mathrm{C}$ to constant mass. Oven-dried plant samples from the second cut (midJuly) were ground and analyzed for total N concentration using a CNS elemental analyser (Elementar Vario El, Hanau, Germany). Plant $\mathrm{N}$ uptake $\left(\mathrm{kg} \mathrm{N}^{-1} \mathrm{yr}^{-1}\right)$ was calculated as: $\mathrm{N}$ concentration $\left(\mathrm{kg} \mathrm{N} \mathrm{kg}^{-1}\right)$ * biomass yield $\left(\mathrm{kg} \mathrm{ha}^{-1} \mathrm{yr}^{-1}\right)$ (Hiremath and Ewel 2001).

\subsubsection{Soil net $\mathbf{N}$ mineralization rates, $\mathrm{N}$ supply, and $\mathrm{N}$ response efficiency}

Net $\mathrm{N}$ mineralization rates were measured five times (April, May, June, August and October) in 2009 and six times (April, May, June, July, August and September) in 2010 using the buried bag method. In each plot, two intact soil cores were taken from the Ah mineral soil (0.01-0.10 m). The soil from one core was transferred into a plastic bag, crumbled, mixed well, and extracted directly in the field by taking a subsample and adding this to a prepared bottle containing $150 \mathrm{ml} 0.5 \mathrm{M} \mathrm{L}^{-1} \mathrm{~K}_{2} \mathrm{SO}_{4}$ (average dry soil mass to solution ratio was 1:3) ( $T_{0}$ cores). The other soil core was put in a plastic bag that was loosely tied to permit aeration but prevent rain from entering, inserted back into the hole to incubate in-situ for ten days, and extracted in a similar manner ( $T_{1}$ cores). The soil- $\mathrm{K}_{2} \mathrm{SO}_{4}$ bottles were brought to the laboratory within 6 hours, where extraction continued by shaking the bottles for one hour and filtering through $\mathrm{K}_{2} \mathrm{SO}_{4}$-prewashed filter papers ( $4 \mu \mathrm{m}$ nominal pore size). Extracts were immediately frozen until analysis. Ammonium $\left(\mathrm{NH}_{4}{ }^{+}\right)$and $\mathrm{NO}_{3}{ }^{-}$were measured using continuous flow injection colorimetry (Skalar, Cenco Instruments, Breda, The Netherlands), in which $\mathrm{NH}_{4}{ }^{+}$was determined using the Berthelot reaction method (Skalar Method 155-000) and $\mathrm{NO}_{3}{ }^{-}$was measured using the copper-cadmium reduction method (Skalar Method 461000). Gravimetric moisture content was determined for each soil sample by oven-drying at $105^{\circ} \mathrm{C}$ for 24 hours. Net $\mathrm{N}$ mineralization was calculated as the difference between $T_{1}$ - and $T_{0}$-mineral $\mathrm{N}\left(\mathrm{NH}_{4}{ }^{+}+\mathrm{NO}_{3}{ }^{-}\right)$. This assay of net production of mineral $\mathrm{N}$ in soil under in-situ conditions in the absence of plants provides an index of plant-available N (Hart et al. 1994).

$\mathrm{N}$ supply of each plot is defined as the sum of cumulative net $\mathrm{N}$ mineralization rates of the soil, $\mathrm{N}$ fertilization and $\mathrm{N}$ deposition rates. Cumulative net $\mathrm{N}$ mineralization rates during a growing season (i.e. April - September) were calculated by applying the trapezoid rule on time intervals between measured rates. For $\mathrm{N}$ deposition, we used a value of $12.6 \mathrm{~kg} \mathrm{~N}$ ha-1 
$\mathrm{yr}^{-1}$ from bulk precipitation measured within the scope of the EU-level II monitoring program (Keuffel-Türk et al. in press). NRE was calculated for each plot as:

NRE $\left(\right.$ kg biomass $\left.\mathrm{kg} \mathrm{N}^{-1}\right)=($ plant $\mathrm{N}$ uptake $\div \mathrm{N}$ supply) $*$ (biomass yield $\div$ plant $\mathrm{N}$ uptake) (Eq. 2)

The ratio of plant $\mathrm{N}$ uptake to $\mathrm{N}$ supply is referred to as $\mathrm{N}$ uptake efficiency whereas the ratio of biomass yield to plant $\mathrm{N}$ uptake is the NUE (Hiremath and Ewel 2001; Pastor and Bridgham 1999).

\subsubsection{Statistical analyses}

Effects of treatments on time series data (net $\mathrm{N}$ mineralization rates) were conducted using linear mixed effects models (LME) with treatments and their interactions as fixed effects and spatial replication and time as random effects. The LME model includes either 1) a variance function that allows different variances of the response variable for the fixed effects, 2) a firstorder temporal autoregressive process that assumes the correlation between measurements decreases with increasing time difference, or 3) both if this improves the relative goodness of model fit based on the Akaike Information Criterion (Crawley 2007). Treatment effects on biomass yield, plant $\mathrm{N}$ uptake, $\mathrm{N}$ supply, NRE, NUE and uptake efficiency were assessed using three-way analysis of variance (ANOVA) with Tukey's HSD test. In all tests, if residual plots revealed non-normal distribution or non-homogeneity of variance, we used either logarithmic or square root transformation (after adding a constant value if the dataset included negative values) and analyses were repeated. Effects were accepted as statistically significant if $P \leq 0.05$. All statistical analyses were conducted using the $\mathrm{R}$ version 2.11 .1 ( $\mathrm{R}$ Development Core Team 2009).

\subsection{Results}

\subsubsection{Biomass yield and plant $\mathrm{N}$ uptake}

In 2009, biomass yield ranged from 4048 to $14647 \mathrm{~kg} \mathrm{ha}^{-1} \mathrm{yr}^{-1}$ with an overall mean of 7758 ( $\pm 309 \mathrm{SE}$ ) $\mathrm{kg} \mathrm{ha}^{-1} \mathrm{yr}^{-1}$. Fertilization as well as increasing mowing frequency increased biomass yield, and plots cut thrice per year responded stronger to fertilization than plots cut once per year (Appendix 1). In 2010, biomass yield decreased to values between 1960 and $12983 \mathrm{~kg} \mathrm{ha}^{-1} \mathrm{yr}^{-1}$ with a mean of $5612 \mathrm{~kg} \mathrm{ha}^{-1} \mathrm{yr}^{-1}$. Compared to 2009, the interaction between mowing frequency and fertilization was even more pronounced (i.e. larger explained variance). Fertilization only resulted in larger yields in plots with three cuts per year whereas 
no fertilization effect could be detected in plots with one cut per year (Appendix 1). Apart from fertilization and mowing frequency, sward composition also influenced biomass yield in 2010 but it explained only a small fraction of the variation. Control swards had larger yields compared to monocot-enhanced swards and both did not differ from dicot-enhanced swards.

Plant $\mathrm{N}$ uptake in 2009 ranged from 51.37 to $340.84 \mathrm{~kg} \mathrm{~N} \mathrm{ha}^{-1} \mathrm{yr}^{-1}$ with a mean of 147.38 ( \pm 17.37 SE) $\mathrm{kg} \mathrm{ha}^{-1} \mathrm{yr}^{-1}$. Fertilization significantly enhanced plant $\mathrm{N}$ uptake and explained by far the largest part of its variance. This was followed by mowing frequency with larger plant $\mathrm{N}$ uptake in plots cut thrice than once a year (Table 2). However, an interaction between fertilization and mowing frequency showed that mowing frequency only affected plant $\mathrm{N}$ uptake on the fertilized plots. In 2010, plant $\mathrm{N}$ uptake ranged from 27.82 to $273.39 \mathrm{~kg}$ $\mathrm{N} \mathrm{kg}^{-1} \mathrm{yr}^{-1}$ with a mean of 98.87 ( $\left.\pm 11.65 \mathrm{SE}\right) \mathrm{kg} \mathrm{ha}^{-1} \mathrm{yr}^{-1}$. As before, fertilization, mowing frequency and their interaction showed significant effects with larger plant $\mathrm{N}$ uptake in fertilized than unfertilized plots, and in plots cut thrice than once per year. The effect of fertilization was less pronounced and that of mowing frequency was larger compared to 2009. Mowing frequency significantly affected plant $\mathrm{N}$ uptake on both fertilized and unfertilized plots, but fertilized plots were more strongly influenced than unfertilized plots (Table 2). 
Table 2: Plant $\mathrm{N}$ uptake of a grassland under different management practices in the Solling Mountains, Germany.

\begin{tabular}{|c|c|c|c|c|c|c|c|c|c|c|}
\hline \multirow[t]{2}{*}{ Main factors } & \multirow[t]{2}{*}{ Treatments } & \multirow[t]{2}{*}{$\mathrm{n}$} & \multicolumn{4}{|c|}{2009} & \multicolumn{4}{|c|}{2010} \\
\hline & & & $\begin{array}{l}\text { Plant N uptake } \\
\left(\mathrm{kg} \mathrm{N} \mathrm{ha}^{-1} \mathrm{yr}^{-1}\right)\end{array}$ & $\mathrm{SE}$ & $P$ & $\begin{array}{c}\text { Variance } \\
\text { explained } \\
(\%)\end{array}$ & $\begin{array}{l}\text { Plant N uptake } \\
\left(\mathrm{kg} \mathrm{N} \mathrm{ha}^{-1} \mathrm{yr}^{-1}\right)\end{array}$ & $\mathrm{SE}$ & $P$ & $\begin{array}{c}\text { Variance } \\
\text { explained } \\
\text { (\%) }\end{array}$ \\
\hline \multirow[t]{4}{*}{ Sward compo } & & & & & 0.540 & 0.21 & & & 0.072 & 1.10 \\
\hline & control & 24 & $147.37 \mathrm{a}$ & 16.24 & & & 106.64 a & 13.03 & & \\
\hline & monocot-enhanced & 24 & 143.20 a & 15.69 & & & $94.23 \mathrm{a}$ & 12.26 & & \\
\hline & dicot-enhanced & 24 & 151.56 а & 14.99 & & & 95.73 а & 10.49 & & \\
\hline \multirow[t]{3}{*}{ Mowing frequ } & & & & & $<0.001$ & 13.17 & & & $<0.001$ & 20.78 \\
\hline & once per year & 36 & $120.11 \mathrm{~b}$ & 8.35 & & & $71.27 \mathrm{~b}$ & 4.06 & & \\
\hline & thrice per year & 36 & 174.65 a & 14.50 & & & 126.46 a & 11.41 & & \\
\hline \multirow[t]{3}{*}{ Fertilization } & & & & & $<0.001$ & 66.88 & & & $<0.001$ & 56.66 \\
\hline & no & 36 & $85.93 \mathrm{~b}$ & 4.15 & & & $59.73 \mathrm{~b}$ & 2.66 & & \\
\hline & NPK & 36 & 208.83 a & 9.47 & & & 138.00 a & 9.78 & & \\
\hline \multicolumn{2}{|c|}{ Fertilization x mowing frequency } & & & & $<0.001$ & 5.40 & & & $<0.001$ & 7.93 \\
\hline no & once per year & 18 & 76.12 с & 3.33 & & & $54.39 \mathrm{~d}$ & 3.26 & & \\
\hline NPK & once per year & 18 & $164.11 \mathrm{~b}$ & 6.91 & & & 88.15 b & 4.87 & & \\
\hline no & thrice per year & 18 & 95.75 c & 6.90 & & & $65.06 \mathrm{c}$ & 3.88 & & \\
\hline NPK & thrice per year & 18 & 253.55 a & 9.28 & & & 187.85 a & 8.81 & & \\
\hline
\end{tabular}

Mean values with different letter indicate significant differences among treatments within main factors or within an interaction of main factors

(three-way ANOVA with Tukey HSD at $\mathrm{P} \leqq 0.05$ ). Treatment interactions that were not significant are not reported. 


\subsubsection{Soil net $\mathbf{N}$ mineralization rates and $\mathbf{N}$ supply}

Net $\mathrm{N}$ mineralization rates showed a clear seasonal pattern with large rates in summer and small rates in spring and fall. In 2009, net $\mathrm{N}$ mineralization rates varied between -13 and 135 $\mathrm{kg} \mathrm{N} \mathrm{ha}{ }^{-1} \mathrm{mo}^{-1}$ with a mean of $29( \pm 3 \mathrm{SE}) \mathrm{kg} \mathrm{N} \mathrm{ha}^{-1} \mathrm{mo}^{-1} . \mathrm{NH}_{4}{ }^{+}$was the dominant form of soil mineral $\mathrm{N}$ before incubation. On average, $\mathrm{NO}_{3}{ }^{-}$constituted $33 \%$ of the soil mineral $\mathrm{N}$ but in $70 \%$ of all cases no $\mathrm{NO}_{3}{ }^{-}$was detectable. Net $\mathrm{N}$ mineralization rates were neither affected by sward composition nor by mowing frequency (Table 3). Only fertilizer application influenced net $\mathrm{N}$ mineralization rates. In 2010, net $\mathrm{N}$ mineralization rates ranged from -29 to $105 \mathrm{~kg} \mathrm{~N} \mathrm{ha}^{-1} \mathrm{mo}^{-1}$ with a mean of 19 ( $\pm 3 \mathrm{SE}$ ) kg N ha ${ }^{-1} \mathrm{mo}^{-1}$. Unlike in 2009, not only fertilization but also mowing frequency influenced net $\mathrm{N}$ mineralization rates: plots cut once per year showed larger net $\mathrm{N}$ mineralization rates than plots cut three times per year.

$\mathrm{N}$ supply in 2009 ranged from 15 to $1003 \mathrm{~kg} \mathrm{~N} \mathrm{ha}^{-1} \mathrm{yr}^{-1}$ with a mean of 278 ( $\pm 25 \mathrm{SE}$ ) $\mathrm{kg} \mathrm{N} \mathrm{ha}^{-1} \mathrm{yr}^{-1}$. In 2010, $\mathrm{N}$ supply ranged from 22 to $823 \mathrm{~kg} \mathrm{~N} \mathrm{ha}^{-1} \mathrm{yr}^{-1}$ with a mean of 217 ( \pm $18 \mathrm{SE}) \mathrm{kg} \mathrm{N} \mathrm{ha}^{-1} \mathrm{yr}^{-1}$. In both years, fertilization $(P=0.000)$ was the only factor influencing $\mathrm{N}$ supply. 
Table 3: Soil net N mineralization rates of a grassland under different management practices in the Solling Mountains, Germany.

\begin{tabular}{|c|c|c|c|c|c|c|c|c|}
\hline \multirow{2}{*}{ Main factors } & \multirow{2}{*}{ Treatments } & \multirow{2}{*}{$\mathrm{n}$} & \multicolumn{3}{|c|}{2009} & \multicolumn{3}{|c|}{2010} \\
\hline & & & $\begin{array}{c}\text { Net } \mathrm{N} \\
\text { mineralization } \\
\left(\mathrm{kg} \mathrm{N} \mathrm{ha}^{-1} \mathrm{mo}^{-1}\right.\end{array}$ & SE & $P$ & $\begin{array}{c}\text { Net } \mathrm{N} \\
\text { mineralization } \\
\left(\mathrm{kg} \mathrm{N} \mathrm{ha}^{-1} \mathrm{mo}^{-1}\right)\end{array}$ & SE & $P$ \\
\hline \multicolumn{2}{|c|}{ Sward composition } & & & & 0.560 & & & 0.160 \\
\hline & control & 24 & 30.69 a & 11.70 & & 16.75 а & 7.87 & \\
\hline & dicot-enhanced & 24 & 25.56 a & 8.42 & & $24.20 \mathrm{a}$ & 9.47 & \\
\hline & monocot-enhanced & 24 & $21.19 \mathrm{a}$ & 7.58 & & $18.05 \mathrm{a}$ & 5.88 & \\
\hline \multicolumn{2}{|c|}{ Mowing frequency } & & & & 0.400 & & & 0.018 \\
\hline & once per year & 36 & 24.77 a & 7.69 & & $22.54 \mathrm{a}$ & 3.76 & \\
\hline & thrice per year & 36 & 26.83 a & 7.69 & & $16.76 \mathrm{~b}$ & 2.79 & \\
\hline \multirow[t]{3}{*}{ Fertilization } & & & & & $<0.001$ & & & 0.009 \\
\hline & no & 36 & $13.50 \mathrm{~b}$ & 3.47 & & $15.48 \mathrm{~b}$ & 2.58 & \\
\hline & NPK & 36 & 38.12 a & 9.89 & & 23.84 a & 3.97 & \\
\hline
\end{tabular}

Mean values with different letter indicate significant differences among treatments within main factors or within an interaction of main factors

(Linear mixed effects Model at $\mathrm{P} \leqq 0.05$ ). Treatment interactions that were not significant are not reported 


\subsection{3 $\mathrm{N}$ response efficiency, $\mathrm{N}$ uptake efficiency and $\mathrm{N}$ use efficiency}

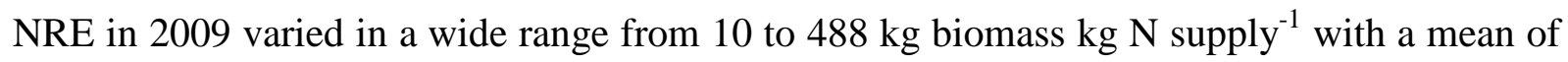
48 ( \pm 7 SE) kg biomass kg $\mathrm{N}_{\text {supply }}^{-1}$. Fertilization was the main factor influencing NRE, with larger efficiency in unfertilized plots compared to fertilized plots (Table 4). Mowing frequency was the second important factor that explained the variance, with larger NRE in plots cut thrice than once per year. In 2010, NRE did not differ from 2009 with values ranging from 5 to $162 \mathrm{~kg}$ biomass $\mathrm{kg} \mathrm{N}$ supply $^{-1}$ and a mean of 42 ( $\pm 4 \mathrm{SE}$ ) kg biomass kg N supply ${ }^{-1}$. All three factors significantly affected NRE in 2010, with fertilization explaining the largest part of the variance followed by mowing frequency and sward composition. NRE was larger in unfertilized than in fertilized plots. The interaction between sward composition and mowing frequency indicated that regardless of mowing frequency, control plots showed an NRE comparable to the monocot- and dicot-enhanced plots that were cut thrice a year and that these NRE were larger than those in monocot- and dicot-enhanced plots cut once a year (Table 4). Within the covered range of $\mathrm{N}$ supply, NRE increased monotonically with decreasing $\mathrm{N}$ supply (Fig. 3a).

$\mathrm{N}$ uptake efficiency in 2009 was largely affected by fertilization with larger efficiencies in unfertilized plots compared to fertilized plots (Table 5). Mowing frequency explained a small part of the variance with larger efficiencies in plots cut thrice per year than plots cut only once per year. In 2010, mowing frequency explained a larger part of the variance than fertilization. In addition, sward composition marginally influenced $\mathrm{N}$ uptake efficiency with a larger efficiency in control swards than monocot- and dicot-enhanced swards (Table 5). The pattern between NRE and $\mathrm{N}$ uptake efficiency showed increasing NRE with increasing $\mathrm{N}$ uptake efficiency (Fig. 3b).

NUE was affected by all three factors in 2009 (Table 6). Fertilization was the most important factor influencing NUE. Unfertilized plots showed larger NUE than fertilized plots. Mowing was the second most important factor. Plots cut once per year showed larger NUE than plots cut thrice per year. This trend, however, was only significant for the unfertilized plots, based on fertilization and mowing interaction effect. Sward composition had the smallest influence with the largest NUE in monocot-enhanced swards, intermediate NUE in control swards and smallest NUE in dicot-enhanced swards. In 2010, fertilization was the only factor influencing NUE (Table 6). The trend between NRE and NUE was more scattered (Fig. 3c) than the pattern between NRE and N uptake efficiency (Fig. 3b). 
Table 4: $\mathrm{N}$ response efficiency (NRE) of a grassland under different management practices in the Solling Mountains, Germany.

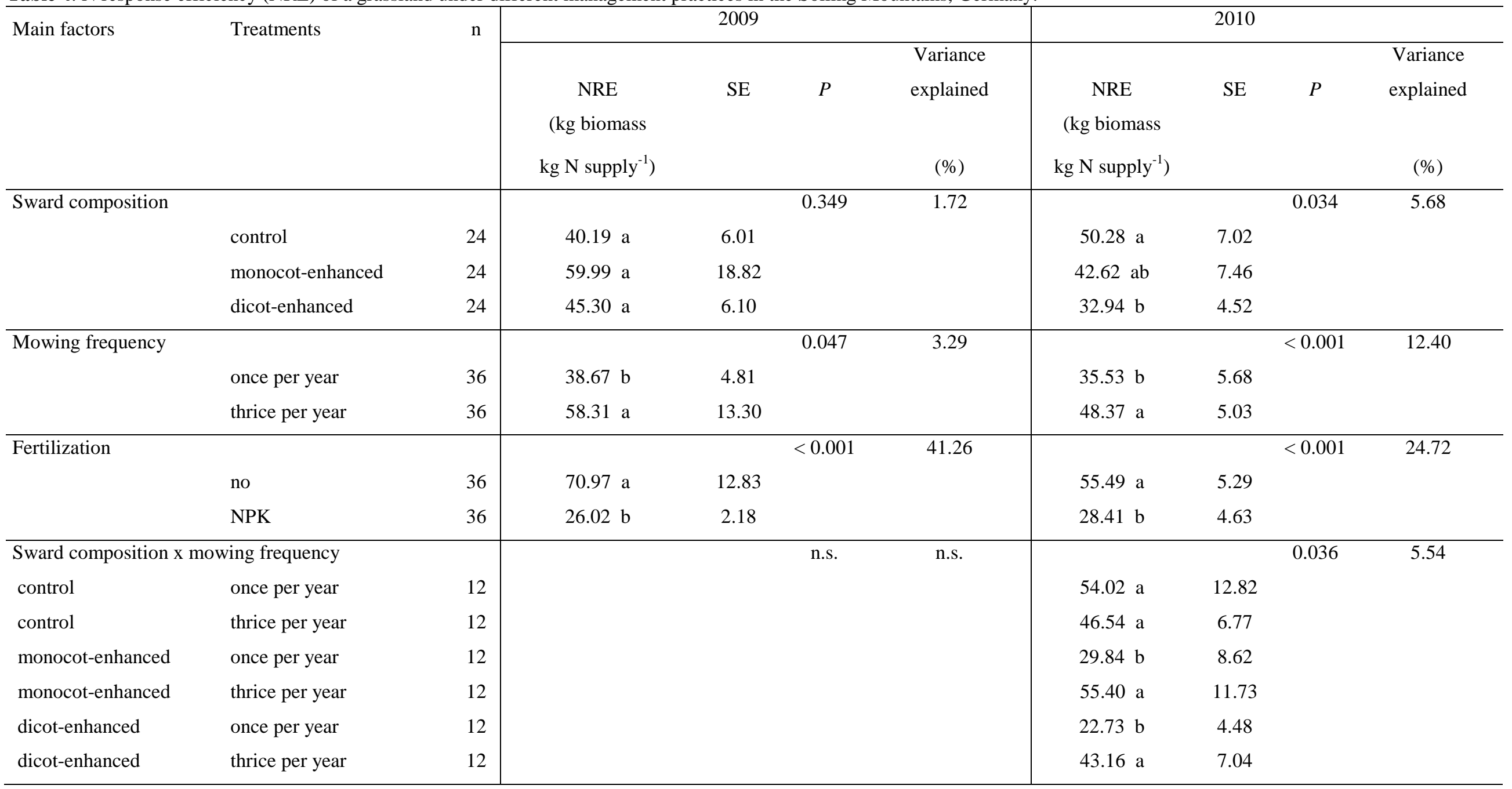

Mean values with different letter indicate significant differences among treatments within main factors or within an interaction of main factors

(three-way ANOVA with Tukey HSD at $\mathrm{P} \leqq 0.05$ ). Treatment interactions that were not significant are not reported (n.s. = not significant). 
Table 5: N uptake efficiency of a grassland under different management practices in the Solling Mountains, Germany.

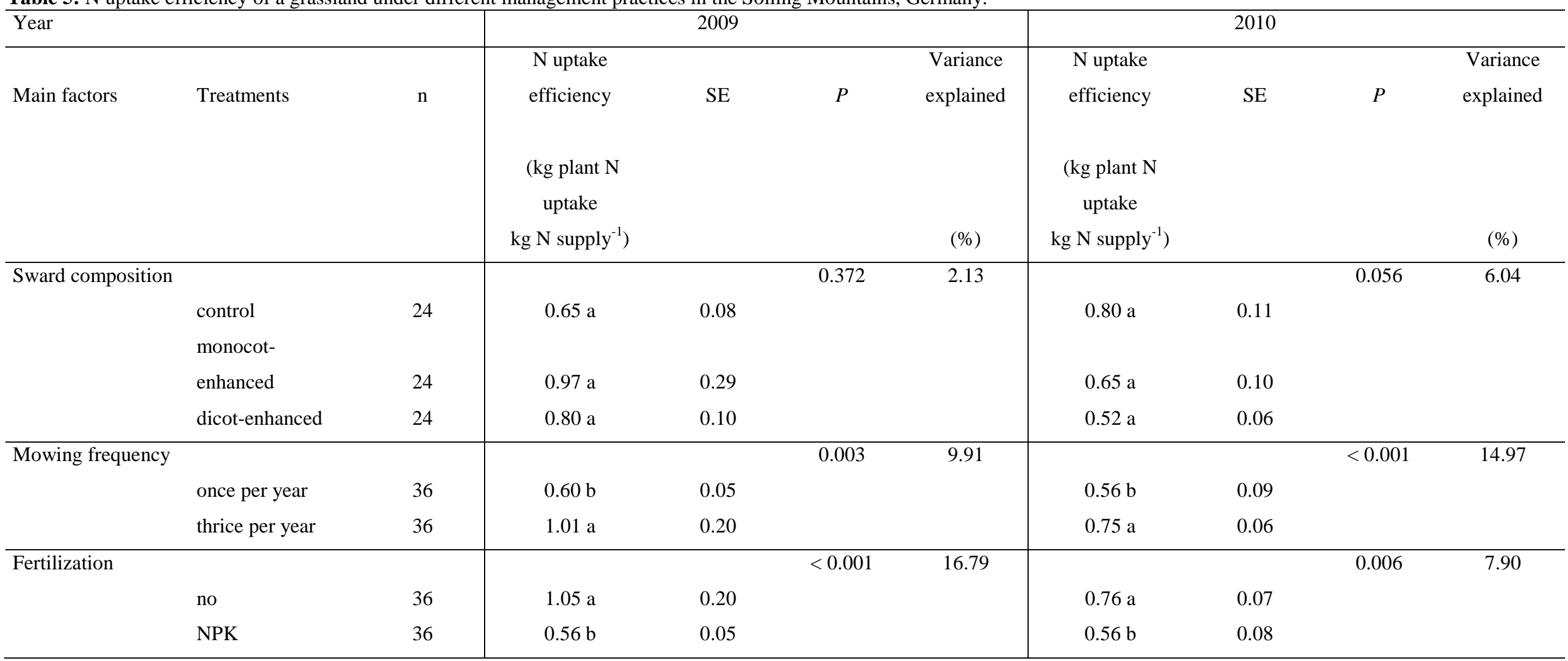

Mean values with different letter indicate significant differences among treatments within main factors or within an interaction of main factors

(three-way ANOVA at $\mathrm{P} \leqq 0.05$ ). Treatment interactions that were not significant are not reported. 
Table 6: $\mathrm{N}$ use efficiency (NUE) of a grassland under different management practices in the Solling Mountains, Germany.

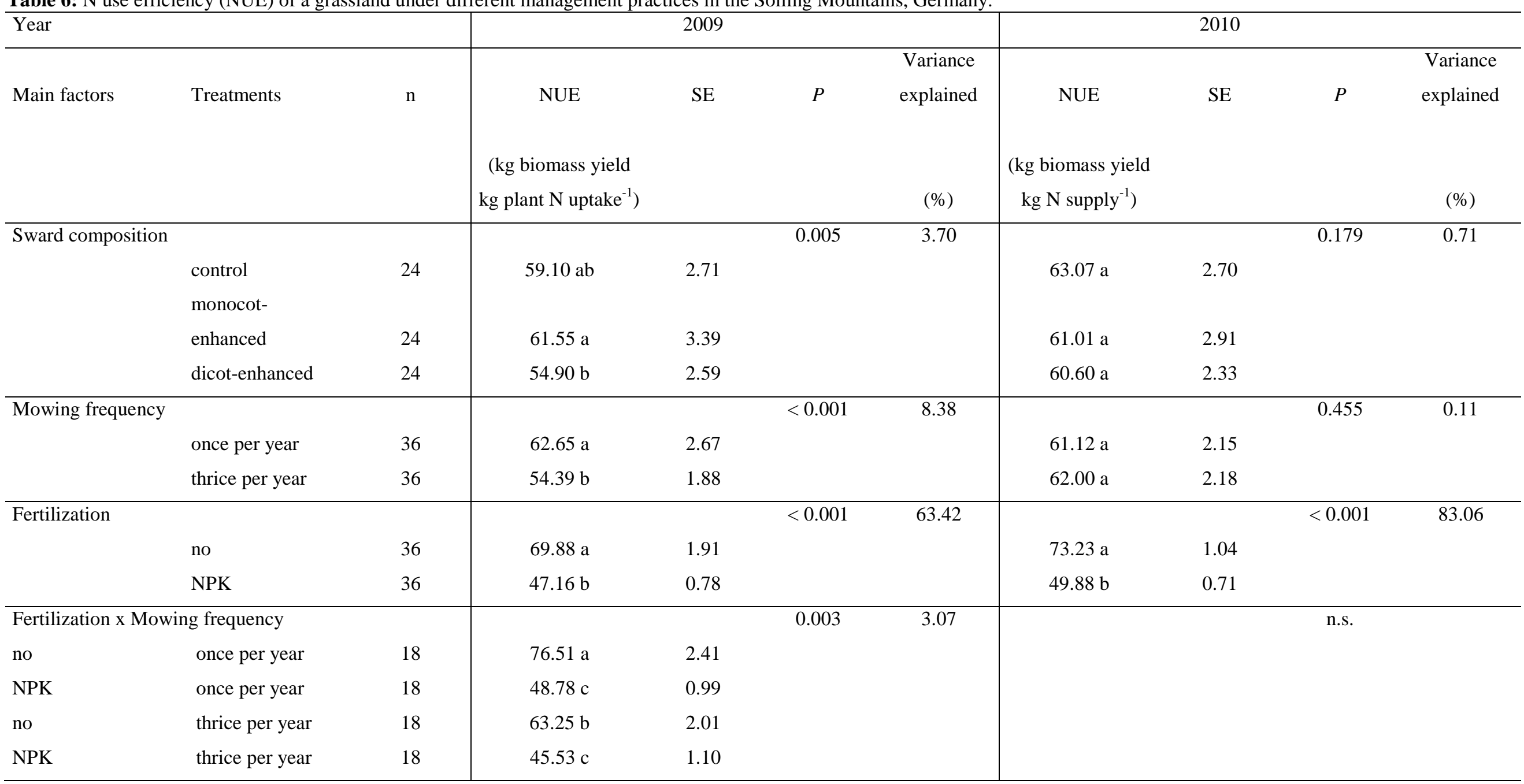

Mean values with different letter indicate significant differences among treatments within main factors or within an interaction of main factors

(three-way ANOVA with Tukey HSD at $\mathrm{P} \leqq 0.05$ ). Treatment interactions that were not significant are not reported (n.s. = not significant). 

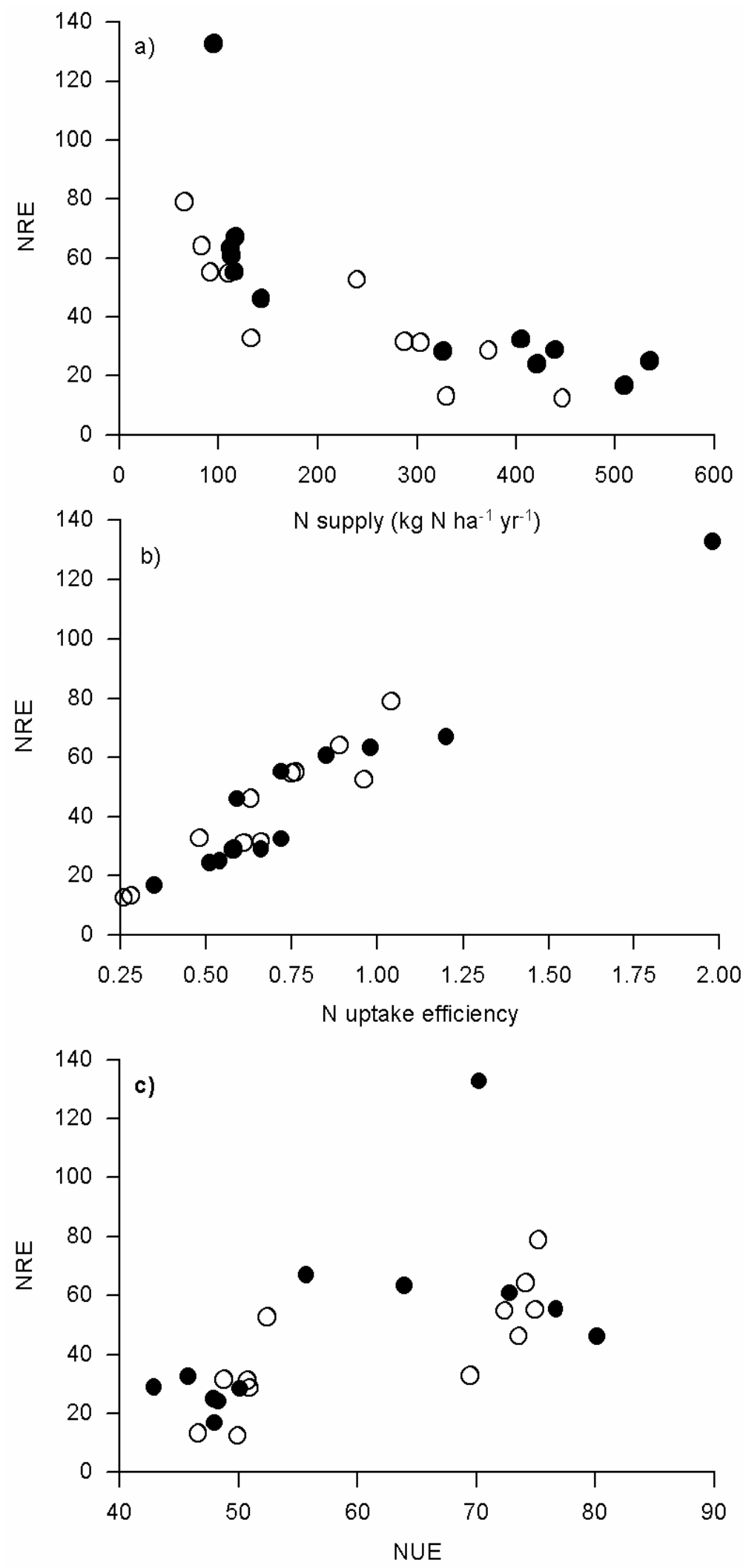

Figure 3: Trends between $\mathrm{N}$ response efficiency (NRE) and (a) $\mathrm{N}$ supply, (b) $\mathrm{N}$ uptake efficiency and (c) $\mathrm{N}$ use efficiency (NUE) of a grassland in the Solling Mountains, Germany across different sward compositions, mowing frequency, and fertilization treatments. Each data point is the mean of six replicates per treatment for 2009, $\bigcirc$ for 2010). No statistical test was conducted because the $\mathrm{X}$ variables are components of the $\mathrm{Y}$ variable. 


\subsection{Discussion}

\subsubsection{Soil net $\mathbf{N}$ mineralization, plant $\mathbf{N}$ uptake and biomass yield}

The substantial increase of net $\mathrm{N}$ mineralization following first fertilization in 2009 was probably caused by a priming effect. Priming effects are changes in mineralization processes caused by moderate addition of nutrients to the soil, e.g. the input of a limiting factor for microbial biomass (Kuzyakov et al. 2000). Our experimental site had been used for hay production and cattle grazing since the early $20^{\text {th }}$ century. Only during the last five decades, a minimal fertilizer addition of $80 \mathrm{~kg} \mathrm{~N} \mathrm{ha}^{-1} \mathrm{yr}^{-1}$ was practiced. It is thus likely that the activity of microbial biomass was stimulated by the addition of $180 \mathrm{~kg} \mathrm{~N} \mathrm{ha}^{-1} \mathrm{yr}^{-1}$ at the beginning of our study. The reduction in net $\mathrm{N}$ mineralization rates in fertilized plots in the second year compared to the first year is also indicative of a priming effect, which has been suggested to be short term (Kuzyakov et al. 2000). While the addition of $\mathrm{N}$ fertilizer initially stimulates mineralization after a long period of $\mathrm{N}$ limitation, regular $\mathrm{N}$ additions may not increase $\mathrm{N}$ cycling continuously (Hassink 1994). The decreased net $\mathrm{N}$ mineralization rates with increased mowing frequency in the second year could be due to reduced input of organic matter into the soil as a consequence of the removal of biomass (Holt 1997; Mikola et al. 2001; Northup et al. 1999; Sankaran and Augustine 2004). Alternatively, it is possible that the reduced net $\mathrm{N}$ mineralization rates on the plots cut thrice per year could also be caused by large $\mathrm{N}$ immobilization by the microbial community, which may result from increased rhizodeposition following defoliation (Holland et al. 1996). Such an explanation is corroborated by the findings of Guitian and Bardgett (2000) who observed increased soil microbial biomass caused by defoliation of grass.

Within the range of $\mathrm{N}$ supply covered in our study, the linear increase of plant $\mathrm{N}$ uptake was reflected by similar trends of increases in aboveground biomass yield and plant $\mathrm{N}$ concentrations (data not shown). The enhanced plant $\mathrm{N}$ uptake by more frequent mowing could be possibly due to 1) increased root-to-shoot ratio by intensive mowing (Kammann et al. 1998; Mooney and Winner 1991), which may then result in large nutrient uptake by plants, and 2) defoliation-induced increase in resource allocation to shoots, as reported by Guitian and Bardgett (2000) for grazing-tolerant grasses. However, for our study site, fine-root biomass and root length density measured in the control swards in September 2009 were not affected by mowing frequency (Rose et al. 2011).

Thus, it is likely that our observed increased plant $\mathrm{N}$ uptake by more frequent mowing is due to increased resource allocation to shoots and overcompensatory response to defoliation (Ferraro and Oesterheld 2002; Guitian and Bardgett 2000). 
Our finding that the dicot-enhanced swards (with equal proportions of dicots and monocots) did not result in a larger biomass yield compared to control and monocot-enhanced swards contrasts to the findings of Hector et al. (1999) and Weigelt et al. (2009) who reported a reduction of aboveground biomass with loss of functional groups in European grasslands. Furthermore, the number of plant species was not responsible for differences in biomass yield. Dicot-enhanced and monocot-enhanced swards showed no significant differences in biomass yield although the numbers of species were different, which is not consistent to the biodiversity-productivity theory (e.g. Hector et al. 1999; Tilman et al. 1996; Weigelt et al. 2009). However, as we only considered harvestable, aboveground biomass, inclusion of belowground biomass may lead to different results.

\subsubsection{N response efficiency}

To our knowledge, published information about NRE in grassland ecosystems is extremely limited and definitions of NRE are not consistent in literature (Xu et al. 2012; Aerts 1990; Vitousek 1982). Unlike other NRE and NUE studies that used litterfall N concentrations as an index of $\mathrm{N}$ availability (Vitousek 1982) or measured mineral $\mathrm{N}$ concentrations in soil (Bridgham et al. 1995), we used in-situ measured net $\mathrm{N}$ mineralization rates as an index of soil plant-available N (Hart et al. 1994). Our measured NRE values were smaller than those reported by Yuan et al. (2006) for a semi-arid grassland in China. Apart from site-specific differences between our and their study sites, the differences in NRE could also be due to the different measures used for $\mathrm{N}$ supply and biomass production. On the one hand, our estimate of $\mathrm{N}$ supply included fertilization, $\mathrm{N}$ deposition and cumulative net $\mathrm{N}$ mineralization rates during the growing season, resulting in large values of $\mathrm{N}$ supply and thus small NRE. On the other hand, Yuan et al. (2006) included not only aboveground but also belowground biomass production, which would lead to large NRE.

Our finding that NRE was largely influenced by fertilization was similar with those of Hiremath and Ewel (2001) who reported that NRE (which they termed ecosystem-level NUE) was negatively correlated with mean annual net nitrification rate, used as an index of soil $\mathrm{N}$ supply. The smaller NRE of the fertilized than unfertilized plots was caused by decreases in both $\mathrm{N}$ uptake efficiency and NUE. The monotonic increase in NRE with decreasing N supply was also consistent with the findings of Yuan et al. (2006), and was unlike the unimodal curve between NRE and soil net $\mathrm{N}$ mineralization rates (ranging from 25-85 kg N ha ${ }^{-1} \mathrm{yr}^{-1}$ ) modelled by Bridgham et al. (1995) for temperate forests. This also supports the suggestion that the unimodal NRE curve may only be applicable for ecosystems with small $\mathrm{N}$ availability (Yuan et al. 2006). The second most important factor influencing NRE was mowing 
frequency. The increased NRE in plots cut thrice per year was largely due to increasing $\mathrm{N}$ uptake efficiency since NUE was either showing the opposite trend or not affected by mowing at all. The increased $\mathrm{N}$ uptake efficiency in plots cut thrice per year was caused by increased biomass yield and $\mathrm{N}$ concentration in biomass.

Finally, sward composition influenced NRE although to a lesser extent than fertilization and mowing frequency. Compared to the influence of sward compositions on biomass yield, where dicot-enhanced swards did not differ from control swards, the influence of sward composition on NRE was more pronounced and explained a larger part of the variance. The trends of NRE and $\mathrm{N}$ uptake efficiency among sward compositions were similar whereas NUE exhibited either opposite patterns or was not affected by sward composition. This emphasizes that NRE of the different sward compositions was influenced more by $\mathrm{N}$ uptake efficiency rather than by NUE and is contrary to the findings of van Ruijven and Berendse (2005) who observed an increasing NUE with increasing species richness in a grassland system without legumes. In our study site, legumes were only present in the control- (1-4\% abundance) and dicot-enhanced (4-9\%) swards. The presence of legumes however cannot support the pattern of differences in NRE among sward compositions but instead the interaction between sward composition and mowing frequency. For example, since we did not account the $\mathrm{N}$ input from $\mathrm{N}$-fixing legumes in our NRE calculation, this could have led to an underestimation of $\mathrm{N}$ supply and thus an overestimation of NRE in the control and dicot-enhanced swards. Instead we found that the monocotenhanced swards (no legumes) had comparable NRE with the control and dicot-enhanced swards all cut thrice a year and the lowest NRE was found in both monocot- and dicotenhanced swards cut once per year (Table 4). The patterns of NRE cannot also be explained by the difference in plant species number. NRE of monocot-enhanced swards which had the smallest number (12-13) of species did not significantly differ from NRE of dicot-enhanced swards (17 species). According to Roy (2001) 90\% of the biodiversity effect on productivity is reached at five species, implying that the difference in plant species in our experiment is larger than the threshold number and effects might not be detectable (Wrage et al. 2011). In contrast to the number of species, the proportions of plant functional groups did have a significant impact on NRE. The proportions of $\sim 30 \%$ dicots and $\sim 70 \%$ monocots found in the control swards showed the largest NRE. We think that over the past decades N-limited conditions and prevailing management practices have led to an equilibrium in this grassland ecosystem in which optimal proportions of monocots and dicots developed to maximize NRE. As a result, an artificial increase in the proportion of dicots as well as in the proportion of monocots would lead to a smaller NRE. Thus, our results suggest that in addition to the effect 
of life-form diversity (Hiremath and Ewel 2001) also the proportions of different plant functional groups affect NRE of an ecosystem.

\subsection{Conclusions}

Our results show that management largely influenced NRE whereas plant functional group diversity only played a minor role. Fertilization decreased NRE due to decreases in both $\mathrm{N}$ uptake efficiency and NUE whereas mowing frequency and sward composition affected NRE through N uptake efficiency rather than NUE. The proportions of monocots and dicots in the control plots that were the result of long-term management practices had the largest NRE. Deviations from these proportions - even to more balanced proportions of monocots and dicots - decreased NRE. Our results show that NRE gives important insights in how different management can be evaluated to come up with a more sustainable grassland management. However, our study can only be a first step towards definite recommendations and NRE should be combined with an economic analysis before advices to farmers can be made.

\section{Acknowledgements}

This work is part of the Cluster of Excellence 'Functional Biodiversity Research' and is funded by the State of Lower Saxony, the Ministry of Science and Culture and the Niedersächsisches Vorab. M.D. Corre acknowledges her funding from the Robert Bosch Foundation. We thank D. Boettger, N.C. Meyer, C. Gottwald and P. Aurin for support with experimental set up and field measurements. We thank I. Ostermeyer for the soil texture analysis and the technical assistants of the Soil Science laboratory and the Department of Plant Ecology for soil analyses. We thank T. From and U. Petersen from the Institute of Grassland Science for providing ground plant material and data on biomass yields. We thank C. Scherber for his support with the statistics and N. Wrage for reviewing this manuscript. 


\section{References}

Aerts R (1990): Nutrient use efficiency in evergreen and deciduous species from heathlands. Oecologia 84: 391397.

Blake GR and Hartge KH (1986): Bulk density. In: Klute A (ed) Methods of soil analysis, part 1. Physical and mineralogical methods. Soil Science Society of America, Madison, Wisconsin, USA, p 12.

Bridgham SD, Pastor J, Mc Claugherty CA, and Richardson CJ (1995): Nutrient-use efficiency - a litterfall index, a model, and a test along a nutrient-availability gradient in North-Carolina peatlands. The American Naturalist 145: 1-21.

Crawley M J (2007): The R book. John Wiley \& Sons Ltd, Chinchester, West Sussex.

Dawson LA, Grayston SJ and Paterson E (2000): Effects of grazing on the roots and rhizosphere of grasses. In Lemaire, J Hodgson, A de Moraes, C Nabinger, and P C De F. Carvalho (eds) Dawson LA, Grayston SJ and Paterson E (2000): Effects of grazing on the roots and rhizosphere of grasses.CABI Publishing, Wallingfort, pp 61-84.

Dobermann A (2005): Nitrogen use efficiency - state of the art. In IFA International Workshop on EnhancedEfficiency Fertilizers, Frankfurt, Germany.

Ellenberg H and Leuschner C (2010): Vegetation Mitteleuropas mit den Alpen. Verlag Eugen Ulmer, Stuttgart.

Ferraro DO and Oesterheld M (2002): Effect of defoliation on grass growth. A quantitative review. Oikos 98: 125-133.

Flombaum P and Sala OE (2008): Higher effect of plant species diversity on productivity in natural than artificial ecosystems. Proceedings of the National Academy of Sciences of the United States of America 105: 6087-6090.

From T, Petersen U K, and Isselstein J (2011): Productivity and forage quality of a phytodiverse semi-natural grassland under various management regimes. http://dx.doi.org/10.1038/npre.2011.6622.1.

Guitian R and Bardgett RD (2000): Plant and soil microbial responses to defoliation in temperate semi-natural grassland. Plant Soil 220, 271-277.

Hart SC, Stark JM, Davidson EA, and Firestone MK (1994): Nitrogen mineralization, immobilization, and nitrification. In: Bottomley PS, Angle JS, and Weaver RW (eds) Methods of soil analysis, Part 2. Microbiological and biochemical properties. Soil Science Society of America Book Series, Madison, Wisconsin, USA, pp 985-1018.

Hassink J (1994): Effects of soil texture and grassland management on soil organic C and N and rates of C and N mineralization. Soil Biol. Biochem. 26, 1221-1231.

Hector A, Schmid B, Beierkuhnlein C, et al. (1999): Plant diversity and productivity experiments in European grasslands. Science 286: 1123-1127.

Hiremath AJ and Ewel JJ (2001): Ecosystem nutrient use efficiency, productivity, and nutrient accrual in model tropical communities. Ecosystems 4: 669-682.

Holland EA and Detling JK (1990): Plant-Response to Herbivory and Belowground Nitrogen Cycling. Ecology 71: 1040-1049.

Holland JN, Cheng WX and Crossley DA (1996): Herbivore-induced changes in plant carbon allocation: Assessment of below-ground C fluxes using carbon-14. Oecologia 107: 87-94.

Holt JA (1997): Grazing pressure and soil carbon, microbial biomass and enzyme activities in semi-arid northeastern Australia. Applied Soil Ecology 5: 143-149. 
Isselstein J, Jeangros B, and Pavlu V (2005): Agronomic aspects of extensive grassland farming and biodiversity management. In: Lillak R, Viiralt R, Linke A, and Geherman V (eds) Integrating efficient grassland farming and biodiversity. 13th international occasional symposium of the European Grassland Federation, Tartu, Estonia, pp 427-430.

Iversen CM, Bridgham SD, and Kellogg LE (2010): Scaling plant nitrogen use and uptake efficiencies in response to nutrient addition in peatlands. Ecology 91: 693-707.

Kammann C, Grunhage L, Muller C, Jacobi S, and Jager HJ (1998): Seasonal variability and mitigation options for $\mathrm{N}_{2} \mathrm{O}$ emissions from differently managed grasslands. Environmental Pollution 102: 179-186.

Keuffel-Türk A, Jankowski A, Scheler B, Rademacher P, and Meesenburg H (in press): Stoffeinträge durch Deposition. In: Höper H and Meesenburg H (eds) Tagungsband 20 Jahre Boden-Dauerbeobachtung in Niedersachsen. Landesamt für Bergbau, Energie und Geologie, Hannover.

König N and Fortmann H (1996): Probenvorbereitungs-, Untersuchungs- und Elementbestimmungs- Methoden des Umweltanalytik-Labor der Niedersächsischen Forstlichen Versuchsanstalt und des Zentrallabor II des Forschungszentrums Waldökosysteme. Teil 1: Elementbestimmungsmethoden A-M. Berichte des Forschungszentrums Waldökosysteme der Universität Göttingen.

Kuzyakov Y, Friedel JK and Stahr K (2000): Review of mechanisms and quantification of priming effects. Soil Biology and Biochemistry 32: 1485-1498.

Mikola J, Setala H, Virkajarvi P, et al. (2009): Defoliation and patchy nutrient return drive grazing effects on plant and soil properties in a dairy cow pasture. Ecological Monographs 79: 221-244.

Mikola J, Yeates GW, Barker GM, Wardle DA, and Bonner KI (2001): Effects of defoliation intensity on soil food-web properties in an experimental grassland community. Oikos 92: 333-343.

Mooney HA and Winner WE (1991): Partitioning response of plants to stress. In: Mooney HA, Winner WE, and Pell EJ (eds) Responses of plants to multiple stresses. Academic Press, San Diego, pp 129-141.

Northup BK, Brown JR and Holt JA (1999): Grazing impacts on the spatial distribution of soil microbial biomass around tussock grasses in a tropical grassland. Applied Soil Ecology 13: 259-270.

Pastor J and Bridgham SD (1999): Nutrient efficiency along nutrient availability gradients. Oecologia 118: 5058.

Petersen U, Wrage N, Köhler L, Leuschner C, and Isselstein J (2011): Manipulating the species composition of permanent grasslands - a new approach to biodiversity experiments. Basic and Applied Ecology. doi:10.1016/j.baae.2011.10.003.

Pykälä J (2000): Mitigating human effects on European biodiversity through traditional animal husbandry. Conservation Biology 14: 705-712.

R Development Core Team (2009) R: A language and environment for statistical computing. R Foundation for Statistical Computing, Vienna, Austria.

Rose L, Coners H, and Leuschner C (2011): Effects of fertilization and cutting frequency on the water balance of a temperate grassland. Ecohydrology 5: 64-72.

Roy J (2001): How does biodiversity control primary productivity? In: Roy J, Saugier B and Mooney HA (eds) Terrestrial global productivity. Academic Press, San Diego, pp 169-186.

Sankaran M and Augustine DJ (2004): Large herbivores suppress decomposer abundance in a semiarid grazing ecosystem. Ecology 85: 1052-1061.

Schlichting E, Blume HP, and Stahr K (1995): Bodenkundliches Praktikum. Blackwell Wissenschafts-Verlag, Berlin, Wien. 
Tilman D, Wedin D, and Knops J (1996): Productivity and sustainability influenced by biodiversity in grassland ecosystems. Nature 379: 718-720.

Van Ruijven J and Berendse F (2005): Diversity-productivity relationships: Initial effects, long-term patterns, and underlying mechanisms. Proceedings of the National Academy of Sciences of the United States of America 102: 695-700.

Vitousek PM (1982) Nutrient cycling and nutrient use efficiency. The American Naturalist 119: 553-572.

Vitousek PM and Howarth RW (1991): Nitrogen limitation on land and in the sea - how can it occur? Biogeochemistry 1: 87-115.

Weigelt A, Weisser WW, Buchmann N, and Scherer-Lorenzen M (2009): Biodiversity for multifunctional grasslands: equal productivity in high-diversity low-input and low-diversity high-input systems. Biogeosciences 6: 1695-1706.

Wrage N, Strodthoff J, Cuchillo M H, Isselstein J, and Kayser M (2011): Phytodiversity of temperate permanent grasslands: Ecosystem services for agriculture and livestock management for diversity conservation. Biodiversity and Conservation. DOI : 10.1007/s10531-011-0145-6, 3317-3339.

Yuan ZY, Li LH, Han XG, et al. (2006): Nitrogen response efficiency increased monotonically with decreasing soil resource availability: a case study from a semiarid grassland in northern China. Oecologia 148: 564-572.

Xu G, Fan X, and Miller A J (2012): Plant nitrogen assimilation and use efficiency. Annual Review of Plant Biology 63: 153-182. 


\section{Appendix}

Appendix 1: Biomass yield of a grassland under different management practices in the Solling Mountains, Germany.

\begin{tabular}{|c|c|c|c|c|c|c|c|c|c|c|}
\hline \multirow{2}{*}{ Main factors } & \multirow{2}{*}{ Treatments } & \multirow{2}{*}{$\mathrm{n}$} & \multicolumn{4}{|c|}{2009} & \multicolumn{4}{|c|}{2010} \\
\hline & & & $\begin{array}{l}\text { Biomass yield * } \\
\left.\text { (kg ha }^{-1} \mathrm{yr}^{-1}\right)\end{array}$ & SE & $P$ & $\begin{array}{c}\text { Variance } \\
\text { explained } \\
\text { (\%) }\end{array}$ & $\begin{array}{l}\text { Biomass yield } \\
\left.\text { (kg ha }^{-1} \mathrm{yr}^{-1}\right)\end{array}$ & SE & $P$ & $\begin{array}{c}\text { Variance } \\
\text { explained } \\
(\%)\end{array}$ \\
\hline \multirow[t]{4}{*}{ Sward composi } & & & & & 0.648 & 0.28 & & & 0.007 & 2.34 \\
\hline & control & 24 & 7922.82 a & 597.58 & & & $6132.01 \mathrm{a}$ & 536.79 & & \\
\hline & monocot-enhanced & 24 & 7763.22 a & 508.89 & & & $5237.22 \mathrm{~b}$ & 498.97 & & \\
\hline & dicot-enhanced & 24 & 7586.48 а & 482.80 & & & $5467.27 \mathrm{ab}$ & 467.66 & & \\
\hline \multirow[t]{3}{*}{ Mowing freque } & & & & & $<0.001$ & 12.01 & & & $<0.001$ & 34.92 \\
\hline & once per year & 36 & $6855.40 \mathrm{~b}$ & 270.55 & & & $4146.09 \mathrm{~b}$ & 172.92 & & \\
\hline & thrice per year & 36 & 8659.62 а & 517.05 & & & 7078.25 a & 446.14 & & \\
\hline \multirow[t]{3}{*}{ Fertilization } & & & & & $<0.001$ & 56.74 & & & $<0.001$ & 24.71 \\
\hline & no & 36 & $5797.13 \mathrm{~b}$ & 167.30 & & & $4378.75 \mathrm{~b}$ & 210.25 & & \\
\hline & NPK & 36 & 9717.88 а & 373.43 & & & 6845.59 а & 469.71 & & \\
\hline \multicolumn{2}{|c|}{ Mowing frequency x fertilization } & & & & $<0.001$ & 9.89 & & & $<0.001$ & 16.97 \\
\hline once per year & no & 18 & $5713.66 \mathrm{c}$ & 160.04 & & & $3934.60 \mathrm{~b}$ & 248.95 & & \\
\hline once per year & NPK & 18 & $7997.14 \mathrm{~b}$ & 349.87 & & & $4357.58 \mathrm{~b}$ & 236.35 & & \\
\hline thrice per year & no & 18 & 5880.61 с & 297.99 & & & $4822.89 \mathrm{~b}$ & 311.13 & & \\
\hline thrice per year & NPK & 18 & 11438.62 а & 321.60 & & & 9333.61 a & 352.58 & & \\
\hline
\end{tabular}

* Biomass yield data was reported by From et al. (2011). Mean values with different letter indicate significant differences among treatments within main factors or within an interaction of main factors (three-way ANOVA with Tukey HSD at $\mathrm{P} \leqq 0.05$ ). Treatment interactions that were not significant are not reported. 


\section{NITROGEN RETENTION EFFICIENCY AND NITROGEN LOSSES OF A MANAGED AND PHYTODIVERSE TEMPERATE GRASSLAND}

Ina Hoeft ${ }^{*}$, Andreas Keuter ${ }^{*}$, Cecille M. Quinones, Paul Schmidt-Walter, Edzo Veldkamp, Marife D. Corre

*these authors contributed equally to this work

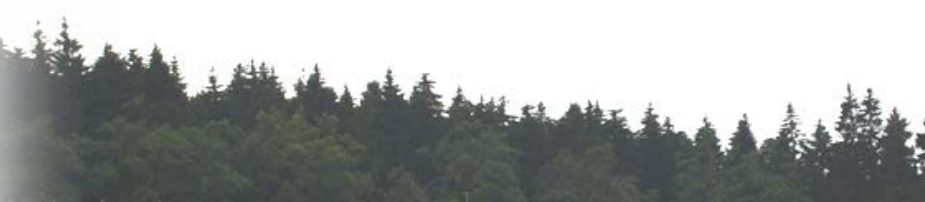




\begin{abstract}
Maintaining nitrogen (N) retention efficiency is crucial in increasing management intensification and decreasing $\mathrm{N}$ losses in temperate grassland. Our aim was to evaluate how grassland management practises and sward composition affect $\mathrm{N}$ retention efficiency, the efficiency with which available $\mathrm{N}$ (indexed by gross $\mathrm{N}$ mineralization) is retained in an ecosystem. A three-factorial grassland management experiment was conducted, including two fertilization treatments, two mowing frequencies and three sward compositions: monocotenhanced, dicot-enhanced and control swards.

Differences in $\mathrm{N}$ retention efficiency were rather caused by $\mathrm{N}$ losses $\left(\mathrm{NO}_{3}{ }^{-}, \mathrm{N}_{2} \mathrm{O}\right.$, $\mathrm{DON}$ ) than by gross $\mathrm{N}$ mineralization. Fertilization was the dominant factor influencing $\mathrm{N}$ retention efficiency and $\mathrm{N}$ losses which was mainly caused by decreases in microbial $\mathrm{NH}_{4}{ }^{+}$ immobilization. Intensive mowing partly reduced the high $\mathrm{N}$ losses following fertilization. In contrast to $\mathrm{N}$ losses, $\mathrm{N}$ retention efficiency responded to variations in sward compositions, indicating that it is a more sensitive index. Control swards that have developed under decades of extensive management practices had the highest $\mathrm{N}$ retention efficiency, followed by dicotenhanced and monocot-enhanced swards. This pattern could partly be explained by a complementary plant resource use but was also the result of differences in microbial $\mathrm{NH}_{4}{ }^{+}$ immobilization.

Our study underlines the importance of microbial immobilization for an efficient retention of $\mathrm{N}$ in the plant-soil-system. In contrast to more common indices (e.g. $\mathrm{N}$ response efficiency or $\mathrm{N}$ uptake efficiency), $\mathrm{N}$ retention efficiency considers this pathway and is, thus, a critical factor to consider when evaluating the sustainability of grassland management practices.
\end{abstract}




\subsection{Introduction}

Nitrogen $(\mathrm{N})$ is an essential plant nutrient that limits primary production in many ecosystems, making the use of $\mathrm{N}$ fertilizers widespread in agricultural ecosystems (Vitousek and Howarth 1991). As a result of the growing global population, a more intensive agricultural production and hence an increase in the use of $\mathrm{N}$ fertilizers can be expected in the near future (Galloway et al. 2008). Agricultural intensification is, however, accompanied by negative environmental impacts: considerable amounts of applied fertilizer $\mathrm{N}$ can be lost through nitrate $\left(\mathrm{NO}_{3}{ }^{-}\right)$ leaching or gaseous emissions, e.g. in the form of nitrous oxide $\left(\mathrm{N}_{2} \mathrm{O}\right)$. Leaching of $\mathrm{NO}_{3}{ }^{-}$can be a threat to ground- and surface water quality ( $\mathrm{Di}$ and Cameron 2002) while $\mathrm{N}_{2} \mathrm{O}$ is an important greenhouse gas that also contributes to the depletion of stratospheric ozone (Schlesinger 2009). In agriculture, maintaining soil quality and high yields while minimizing $\mathrm{N}$ losses can only be achieved through efficient retention of $\mathrm{N}$ in the plant-soil system, i.e. available mineral $\mathrm{N}$ should be taken up by plants or immobilized by the microbial community before it is potentially lost through the microbial processes of nitrification and denitrification. $\mathrm{N}$ retention efficiency, the efficiency with which available $\mathrm{N}$ is retained in an ecosystem, is thus an important parameter to evaluate the sustainability of a land use system.

In temperate grasslands $\mathrm{N}$ retention efficiency may be influenced by management practices and plant diversity (Christian and Riche 1998; Flechard et al. 2005; Jones et al. 2005). Application of $\mathrm{N}$ fertilizer typically increases $\mathrm{N}$ losses, while mowing can lead to a more effective plant $\mathrm{N}$ uptake caused by overcompensatory regrowth of plants (Ferraro and Oesterheld 2002) or by a denser root system (Kammann et al. 1998). A more diverse grassland community may have a higher $\mathrm{N}$ retention through complementary resource use, e.g. due to different rooting depths, different forms of $\mathrm{N}$ taken up or $\mathrm{N}$ uptake at different times of the year (e.g. Hooper and Vitousek 1998). It has been reported that increasing plant species diversity reduces the amount of extractable soil mineral N (e.g. Ewel et al. 1991; Niklaus et al. 2001; Tilman et al. 1996), however, most studies have been carried out in artificial and intensively weeded grassland plots, making it difficult to compare with permanent managed grassland. Furthermore, soil $\mathrm{NO}_{3}{ }^{-}$concentrations are not directly related to $\mathrm{NO}_{3}{ }^{-}$leaching complicating their interpretation (Scherer-Lorenzen et al. 2003). To our knowledge, there are only two studies that directly quantified $\mathrm{NO}_{3}{ }^{-}$leaching losses as a function of plant diversity (Hooper and Vitousek 1997; Scherer-Lorenzen et al. 2003) and only one study investigated biodiversity effects on leaching dissolved organic N (DON) (Dijkstra et al. 2007). No studies have been conducted on the effects of mowing on $\mathrm{N}$ leaching. 
In the present study, our goal was to evaluate how $\mathrm{N}$ retention efficiency is influenced by different management treatments (fertilization, mowing frequency) and sward composition (differing in plant functional group compositions and plant species richness) at a temperate grassland. We were especially interested in the question whether management or manipulation of plant functional groups can compensate the high $\mathrm{N}$ losses that are frequently observed following fertilizer application. We tested the following hypotheses: 1) fertilized plots have lower $\mathrm{N}$ retention efficiency (and thus higher $\mathrm{N}$ losses) than unfertilized plots; 2) $\mathrm{N}$ retention efficiency increases (and $\mathrm{N}$ losses decrease) with increasing mowing frequency; 3) $\mathrm{N}$ retention efficiency is highest (and thus $\mathrm{N}$ losses are lowest) in swards with high plant species richness and with equal proportions of different plant functional groups due to complementary resource use.

\subsection{Material and Methods}

\subsubsection{Approach}

We first developed an index that can be used for the evaluation of the ecosystem property $\mathrm{N}$ retention efficiency. Aber and colleagues (1998) use the following index for $\mathrm{N}$ retention efficiency: 1 - (N outputs $\div \mathrm{N}$ inputs)

While this index may work well for forest ecosystems where long datasets of input and output have been collected, it does not account for changes in $\mathrm{N}$ cycling caused by management in agricultural systems. For example, when $\mathrm{N}$ fertilizer is applied, large proportions of applied mineral $\mathrm{N}$ are immediately immobilized by the soil microbial community (Bristow et al. 1987) a process which typically exceeds plant $\mathrm{N}$ uptake (Jackson et al. 1989). This $\mathrm{N}$ will become available later through mineralization. In the present study we account for such processes by using an index that is based on the availability of $\mathrm{N}$, not on $\mathrm{N}$ inputs only and we thus used the following index for $\mathrm{N}$ retention efficiency:

$\mathrm{N}$ retention efficiency $=$

1 - ((N losses (mg N m$\left.{ }^{-2} \mathrm{~d}^{-1}\right) \div$ gross $\mathrm{N}$ mineralization rates $\left(\mathrm{mg} \mathrm{N} \mathrm{m}^{-2} \mathrm{~d}^{-1}\right)$ )

Where the $\mathrm{N}$ losses were the sum of average daily $\mathrm{NO}_{3}{ }^{-}$and DON leaching rates $\left(\mathrm{mg} \mathrm{N} \mathrm{m}^{-2} \mathrm{~d}^{-}\right.$ ${ }^{1}$ ) and mean daily $\mathrm{N}_{2} \mathrm{O}$ emissions rates $\left(\mathrm{mg} \mathrm{N} \mathrm{m}^{-2} \mathrm{~d}^{-1}\right)$. For $\mathrm{N}$ available we used gross $\mathrm{N}$ mineralization because it includes all $\mathrm{N}$ that is actively cycling in the soil and is available to plants and microbial biomass. 


\subsubsection{Study site}

The study (which is part of the GRASSMAN experiment) was conducted on a moderately species rich grassland in the Solling uplands in Lower Saxony, Germany (51 $44^{\prime} 53^{\prime \prime N}$, 9³2'42"E, $490 \mathrm{~m}$ above sea level). This site presently belongs to the experimental farm Relliehausen and has been used for grazing or hay making for at least 100 years (Geological Map of Prussia 1910 (based on the topographic inventory of 1896), topographic maps of Sievershausen and Neuhaus/Solling 1924, 1956 and 1974, Braunschweigische Landesaufnahme, $18^{\text {th }}$ century). Before the experiment started, the grassland was managed extensively by moderate application of fertilizer (80 $\mathrm{kg} \mathrm{N} \mathrm{ha}^{-1} \mathrm{yr}^{-1}$ ), occasional lime application, overseeding with high value forage species and cattle grazing (farm records Relliehausen since 1966). Before the experiment started, vegetation was classified as a montane, semi-moist Lolio-Cynosuretum. Mean annual precipitation is $1031 \mathrm{~mm}$ and mean annual temperature is $6.9^{\circ} \mathrm{C}$ (Deutscher Wetterdienst 1961 - 1990). The soil is a Haplic Cambisol (IUSS Working Group WRB 2006) which developed on loess sediments with a loamy silt texture overlaying rocks of the Middle Buntsandstein formation.

\subsubsection{Experimental set up}

The GRASSMAN-experiment was set up in 2008 as a three-factorial design, including three sward compositions, two mowing frequencies and two NPK-fertilization treatments. Three sward compositions were established by applying a herbicide mixture against dicotyledons (Starane ${ }^{\circledR}$ (active ingredients: Fluoroxypyr and Triclopyr) and Duplosan KV (active ingredients: Mecoprop- $\mathrm{P}())$ ), resulting in a reduced herb and legume sward; a herbicide mixture against monocotyledons (Select 240 EC® by Stähler (active ingredients: Clethodim)) resulting in a reduced grass sward; and an untreated control sward. We refer to these sward compositions as monocot-enhanced (12-13 species; $91-93 \%$ grasses, 7-9\% herbs and 0\% legumes) and dicot-enhanced (17 species; 40-47\% grasses, 49-53\% herbs and 4-9\% legumes) relative to the control sward (16-18 species; 68-76\% grasses, $21-31 \%$ herbs and 1-4\% legumes) (Petersen et al. 2012). All experimental plots were mown and fertilized plots received $50 \mathrm{~kg} \mathrm{~N} \mathrm{ha}^{-1}$ in 2008. In 2009 the experiment started. Half of the plots were mown once per year and the other half of the plots were cut three times per year. Mowing was conducted in July for plots with one-cut per year and in May, July and September for plots with three-cuts per year. A Haldrup (C) forage combine harvester with a cutting height of $7 \mathrm{~cm}$ was used. Half of the plots were fertilized with $180 \mathrm{~kg} N$ per year, $30 \mathrm{~kg}$ phosphorus (P) per year and $100 \mathrm{~kg}$ potassium (K) per year. Mineral N fertilizer (calcium ammonium nitrate N27) 
was split into two equal applications per year (April and May 2009 and April and June 2010) while the combined P and K fertilizer was applied once a year (June 2009 and 2010). The fullfactorial combination of the treatment factors (two fertilization treatments, two mowing frequencies, three sward compositions) led to twelve treatments, each replicated six times. The resulting 72 plots (15 m x 15 m) were arranged in a Latin rectangle.

\subsubsection{Soil characteristics}

A summary of soil characteristics is presented in Table 7. In spring 2008, soil samples were taken at nine sampling points per plot (0.01-0.1 m depth), pooled, oven-dried $\left(40^{\circ} \mathrm{C}\right)$ for a week and sieved (2 mm). Soil bulk density was measured in summer 2009 from undisturbed soil cores (0.00-0.05 m) using the soil core method (Blake and Hartge 1986). Particle size distribution was determined by wet sieving $(>20<630 \mu \mathrm{m})$ and pipette methods $(\leq 20 \mu \mathrm{m})$ after pre-treatment with $30 \% \mathrm{H}_{2} \mathrm{O}_{2}$ and $4 \%$ Na-dithionite-citrate solution. Cation exchange capacity (CEC) was determined using percolation with $0.1 \mathrm{M} \mathrm{BaCl}_{2}$ (König and Fortmann 1996). Cations in percolates were measured with Inductively Coupled Plasma - Optical Emission Spectrometry (ICP-OES; Optima 3000 XL, Perkin Elmer, Rodgau, Germany). Base saturation was determined as the percentage exchangeable base cations of the CEC. Soil pH was measured in distilled water at a soil:water ratio of 1:2. Total concentrations of carbon (C) and $\mathrm{N}$ were determined from ground samples using CN elemental analyzer (Vario EL III, Elementar, Hanau, Germany). 
Table 7: Soil characteristics in the Ah horizon (0.01-0.1 m) of a Haplic Cambisol of a grassland site in the Solling uplands, Germany.

\begin{tabular}{lccc}
\hline Physical and chemical ${ }^{*}$ properties & Mean & SE & 18 \\
\hline Sand (\%) & 21.6 & 1.2 & 18 \\
Silt (\%) & 66.5 & 0.8 & 18 \\
Clay (\%) & 11.9 & 0.0 & 72 \\
Bulk density $\left(\mathrm{g} \mathrm{cm}^{-3}\right)$ & 0.8 & 5.2 & 72 \\
\hline Cation exchange capacity $\left(\mathrm{mmol}_{\mathrm{c}} \mathrm{kg}^{-1}\right)$ & 169 & 1.4 & 72 \\
Base saturation $(\%)$ & 37.2 & 0.0 & 72 \\
pH $\left(1: 2 \mathrm{H}_{2} \mathrm{O}\right)$ & 5.34 & 0.0 & \\
C:N ratio & 12.6 & & 72 \\
\hline
\end{tabular}

* Soil chemical data were provided by the Department of Plant Ecology, University of Göttingen.

\subsubsection{Gross $\mathbf{N}$ transformation rates and microbial biomass}

In September 2010, gross mineralization and nitrification rates were measured using the ${ }^{15} \mathrm{~N}$ pool dilution technique (Davidson et al. 1991) on a selection of treatments. We sampled five replicates per treatment combination, including the three sward treatments and the two fertilization treatments that were cut once per year (in total: $5 \times 3 \times 2=30$ plots). At each sampling plot, two intact soil cores were injected with $\left({ }^{15} \mathrm{NH}_{4}\right)_{2} \mathrm{SO}_{4}$ solution (for gross mineralization and $\mathrm{NH}_{4}{ }^{+}$consumption) and another two intact soil cores were injected with $\mathrm{K}^{15} \mathrm{NO}_{3}$ solution (for gross nitrification). Each soil core received $5 \mathrm{ml}$ injections in five points inside the soil core containing $29.48 \mu \mathrm{g} \mathrm{N} \mathrm{ml}^{-1}\left(\left({ }^{15} \mathrm{NH}_{4}\right)_{2} \mathrm{SO} 4\right)$ and $28.02 \mu \mathrm{g} \mathrm{N} \mathrm{ml}^{-1}\left(\mathrm{~K}^{15} \mathrm{NO}_{3}\right)$ with $99 \%{ }^{15} \mathrm{~N}$ enrichment which is equivalent to an application rate of 0.78 and $0.73 \mu \mathrm{g}{ }^{15} \mathrm{~N}$ $\mathrm{g}^{-1}$, respectively. Ten minutes after ${ }^{15} \mathrm{~N}$ injection one soil core of each labelled pair was broken up, mixed and added to $150 \mathrm{ml} 0.5 \mathrm{~mol} \mathrm{~L}^{-1} \mathrm{~K}_{2} \mathrm{SO}_{4}$ (1:3 fresh soil to $\mathrm{K}_{2} \mathrm{SO}_{4}$ solution) ( $T_{0}$ cores). The reactions that occur immediately after addition of ${ }^{15} \mathrm{NH}_{4}{ }^{+}$and ${ }^{15} \mathrm{NO}_{3}{ }^{-}$were corrected for using the $T_{0}$ cores. The other soil core of the labelled pair was put in a plastic bag, inserted back into the soil to incubate for one day, and extracted with $0.5 \mathrm{~mol} \mathrm{~L}^{-1} \mathrm{~K}_{2} \mathrm{SO}_{4}$ as described above ( $T_{1}$ cores). All soil extracts were shaken for one hour, filtered (4 $\mu \mathrm{m}$ nominal pore size) and stored at $-18^{\circ} \mathrm{C} . \mathrm{NH}_{4}{ }^{+}$and $\mathrm{NO}_{3}{ }^{-}$were measured using continuous flow injection colorimetry, in which $\mathrm{NH}_{4}{ }^{+}$was determined using Berthelot reaction method (Skalar Method 155-000). $\mathrm{NO}_{3}{ }^{-}$was determined using copper-cadmium reduction method (Skalar 
Method 461-000). Gravimetric moisture content was determined after drying at $105^{\circ} \mathrm{C}$ for 24 hours. The diffusion procedures and blank correction for ${ }^{15} \mathrm{~N}$ analysis of the extracts are described by Corre et al. (2007). ${ }^{15} \mathrm{~N}$ analysis was done using isotope ratio mass spectrometry (Finigan MAT, Bremen, Germany). Gross $\mathrm{N}$ mineralization, gross nitrification and $\mathrm{NH}_{4}{ }^{+}$ consumption rates were estimated using the modified calculation procedure of Davidson et al. (1991) from the Kirkham and Bartholomew (1954) model. We were unable to conduct immediate $\mathrm{CHCl}_{3}$ fumigation and calculated $\mathrm{NH}_{4}{ }^{+}$immobilization rates according to Davidson et al. (1991):

$\mathrm{NH}_{4}{ }^{+}$immobilization $=\mathrm{NH}_{4}{ }^{+}$consumption - gross nitrification

For microbial biomass $\mathrm{C}$ and $\mathrm{N}$ in $T_{1}$ fumigated and non-fumigated samples we used fumigation-extraction method (Brookes et al. 1985). Organic $\mathrm{C}$ in $\mathrm{K}_{2} \mathrm{SO}_{4}$ extracts was analyzed by UV-enhanced persulfate oxidation using a Dohrman DC-80 Carbon analyzer with an infrared detector (Rosemount Analytical Division, Santa Clara, California, USA). Organic $\mathrm{N}$ in $\mathrm{K}_{2} \mathrm{SO}_{4}$ extracts was traced by persulfate digestion (Corre et al. 2007), followed by colorimetric analysis of $\mathrm{NO}_{3}{ }^{-}$as described before. Microbial biomass $\mathrm{C}$ and $\mathrm{N}$ were calculated as the difference in extractable organic $\mathrm{C}$ and persulfate- $\mathrm{N}$ between fumigated and unfumigated soils divided by the fraction of biomass $\mathrm{C}$ and $\mathrm{N}$ mineralized, $k_{C}=0.45$ (Joergensen 1996) and $k_{N}=0.68$ for five-day fumigated samples (Shen et al. 1984; Brookes et al. 1985).

\subsubsection{Water balance and $\mathrm{N}$ losses}

$\mathrm{NO}_{3}{ }^{-}$and DON leaching losses were sampled monthly. Weather conditions prevented the sampling from January till February 2009 and 2010 (mean temperature below $0^{\circ} \mathrm{C}$ and snow cover) and in August 2009 and 2010 (not enough precipitation). We installed one ceramic suction cup (P80 ceramic, maximum pore size $1 \mu \mathrm{m}$; CeramTec AG, Marktredwitz, Germany) per plot in a depth of 0.5-0.6 m (below root depth) three months prior to the first sampling. A suction of $-600 \mathrm{hPa}$ was applied by a vacuum pump. $\mathrm{NO}_{3}{ }^{-}$and $\mathrm{DON}$ leachate was collected belowground in $1000 \mathrm{ml}$ glass bottles and stored at $-18^{\circ} \mathrm{C} . \mathrm{NH}_{4}{ }^{+}$and $\mathrm{NO}_{3}{ }^{-}$were measured using continuous flow injection colorimetry, as described before. Dissolved total $\mathrm{N}$ was determined using UV-persulfate oxidation followed by hydrazine sulphate reduction (Skalar Method 473-000). DON was calculated as the difference between dissolved total $\mathrm{N}$ and dissolve inorganic $\mathrm{N}$ (DIN). Total $\mathrm{NO}_{3}{ }^{-}$and DON losses from the profile with leachate were calculated by multiplying the respective concentration with the accumulated daily drainage flux for the corresponding time interval. 
Daily drainage flux was calculated using the 1D-SVAT-model BROOK90 (Federer et al. 2003). As we expected that differences between treatments were negligible, we calculated one drainage flux for all treatments. The model estimates daily evapotranspiration (ET) divided into interception (I) and transpiration ( $\mathrm{T}$ ) from a single-layered canopy as well as soil evaporation (E), using an approach after Shuttleworth and Wallace (1985). The vertical soil water movement for saturated and unsaturated flow followed Darcy's Law and is described by a solution of the Richards equation for the relationships among matrix potential, soil water content and hydraulic conductivity. The drainage flux (S) is taken as the gravitational outflow of water from the deepest soil layer. Driving climatic data (precipitation sum, minimum/maximum air temperature, global radiation sum, average vapour pressure and average wind speed, all on a daily basis) for the model were derived from a weather station of the study site. The model was parameterized according to site conditions and vegetation properties as far as data were available. A soil profile of 13 layers and $1 \mathrm{~m}$ depth was defined with constant soil hydraulic properties derived from soil texture after Clapp and Hornberger (1978) and increasing stone content (8\% in the uppermost 25\% in the deepest layer). The root distribution decreased exponentially to the maximum rooting depth of $0.3 \mathrm{~m}$, with about $70 \%$ of the roots being in the first $0.1 \mathrm{~m}$ of the soil profile. An estimation of the seasonal course of the leaf area index, was derived from average biomass productions according to Rose et al. (2011). To validate the model, we compared the simulated matrix potential-model with measured matrix potential. Matrix potential was measured monthly using tensiometers (P80 ceramic, maximum pore size $1 \mu \mathrm{m}$; CeramTec AG, Marktredwitz, Germany). We installed two tensiometers per depth in $0.2 \mathrm{~m}, 0.5 \mathrm{~m}$ and $0.9 \mathrm{~m}$.

$\mathrm{N}_{2} \mathrm{O}$ emissions were measured seven times in 2009 and five times in 2010 using closed chamber method. One polyvinyl chloride (PVC) chamber base (0.07 $\mathrm{m}^{2}$ area, 0.35-0.4 m height of chamber base and cover) was inserted in each plot. For each measurement, the chamber base was covered with a PVC chamber hood fitted with a vent and an air sample port. Following chamber closure, gas samples were taken in four pre-evacuated $100 \mathrm{ml}$ gas containers with teflon-coated stopcocks at 15 minutes intervals. $\mathrm{N}_{2} \mathrm{O}$ was analyzed using a gas chromatograph (GC 6000, Carlo Erba Instruments/Thermo Fisher Scientific, Milan, Italy) equipped with an electron capture detector and an autosampler system (Loftfield et al. 1997). Gas concentrations were calculated by comparing the sample peak integrals with the peak integrals of three standard gases (2009: 353, 1005 and 1592 ppb $\mathrm{N}_{2} \mathrm{O}$ and 2010: 353, 1018 and 1604 ppb $\mathrm{N}_{2} \mathrm{O}$; Deuste Steiniger GmbH, Mühlhausen, Germany). $\mathrm{N}_{2} \mathrm{O}$ emissions were 
calculated by the linear increase of $\mathrm{N}_{2} \mathrm{O}$ concentration versus time for each chamber, corrected with air temperature, chamber volume and air pressure.

\subsubsection{Statistical analysis}

To test the effects of fertilization, mowing frequency and sward composition in time series data $\left(\mathrm{NO}_{3}{ }^{-}\right.$, DON leaching and $\mathrm{N}_{2} \mathrm{O}$ emissions) we used linear mixed effects models (LME) with treatments factors and row / column of the Latin rectangle design as fixed effects. Sampling date and spatial replication were included as random effects. The LME model included 1) a variance function that allows different variances of the response variable for the fixed effects (Zuur et al. 2009), 2) a first-order temporal autoregressive process that assumes the correlation between measurements decreases with increasing time difference, or both if these improve the relative goodness of model fit based on the Akaike Information Criterion (AIC) (Crawley 2007). Pairwise comparisons (T-Test with Holmes-Correction) were used as post-hoc tests. To test treatment effects on gross $\mathrm{N}$ mineralization, $\mathrm{NH}_{4}{ }^{+}$immobilization, total average $\mathrm{N}$ losses, and $\mathrm{N}$ retention efficiency we used analysis of variance (ANOVA) followed by Tukey's HSD post-hoc test. In all tests, if residual plots revealed non-normal distribution or non-homogeneity of variance we used either logarithmic or square root transformation (after adding a constant value if the dataset included negative values) and analyses were repeated. Non-significant interactions as well as row and column were removed stepwise from the statistical models if this improved AIC (Crawley 2007).

Correlations between $\mathrm{N}$ retention efficiency, soil microbial $\mathrm{C}$ and $\mathrm{N}$ and biomass yield were tested with Spearman's rank correlation. A significance level of $\alpha=0.05$ was used throughout unless stated otherwise. All statistical analyses were performed using the $\mathrm{R}$ version 2.11.1 (R Development Core Team 2009).

\subsection{Results}

\subsubsection{Gross $\mathbf{N}$ transformation rates and microbial biomass}

Rates of gross $\mathrm{N}$ mineralization ranged from 71 to $1440 \mathrm{mg} \mathrm{N} \mathrm{m}^{-2} \mathrm{~d}^{-1}$ with an overall mean of 606 ( $\pm 65 \mathrm{SE}) \mathrm{mg} \mathrm{N} \mathrm{m}^{-2} \mathrm{~d}^{-1}$. Neither fertilization nor sward composition affected gross $\mathrm{N}$ mineralization (Table 8). In contrast, gross nitrification rates were higher on the fertilized plots, while sward composition did not affect gross nitrification. $\mathrm{NH}_{4}{ }^{+}$immobilization (Table 8) varied between 143 and $2356 \mathrm{mg} \mathrm{N} \mathrm{m}^{-2} \mathrm{~d}^{-1}$ with an overall mean of $753( \pm 100 \mathrm{SE}) \mathrm{mg} \mathrm{N}$ $\mathrm{m}^{-2} \mathrm{~d}^{-1}$ and was lower on the fertilized plots (marginally significant). While net $\mathrm{NH}_{4}{ }^{+}$ immobilization (i.e. $\mathrm{NH}_{4}{ }^{+}$immobilization rates $>$gross $\mathrm{N}$ mineralization) occurred on the 
unfertilized plots, on the fertilized plots $\mathrm{NH}_{4}{ }^{+}$immobilization was $90 \%$ of gross $\mathrm{N}$ mineralization with the exception of dicot-enhanced swards which displayed net $\mathrm{NH}_{4}{ }^{+}$ immobilization on both fertilized and unfertilized plots. Microbial C was not affected by any of the treatments, but fertilization resulted in marginally lower microbial $\mathrm{N}$ contents. A marginally significant interaction between fertilization and sward composition suggested that the decrease in microbial $\mathrm{N}$ caused by fertilization was most pronounced at the monocotenhanced swards. A marginally significant interaction between fertilization and sward composition could also be shown for microbial C:N ratios which were highest at the fertilized monocot-enhanced swards. 
Table 8: Gross $\mathrm{N}$ mineralization rates, gross nitrification rates, $\mathrm{NH}_{4}{ }^{+}$immobilization rates, microbial C, microbial $\mathrm{N}$ and microbial C: $\mathrm{N}$ ratios of a grassland under different management practices in the Solling uplands, Germany (mean values $+\mathrm{SE}$ ).

\begin{tabular}{|c|c|c|c|c|c|c|c|c|}
\hline Main factors & Treatments & $\mathrm{n}$ & $\begin{array}{c}\text { Gross } \mathrm{N} \\
\text { mineralization rate } \\
\left(\mathrm{mg} \mathrm{N} \mathrm{m}^{-2} \mathrm{~d}^{-1}\right)\end{array}$ & $\begin{array}{c}\text { Gross } \\
\text { nitrification rate } \\
\left(\mathrm{mg} \mathrm{N} \mathrm{m}^{-2} \mathrm{~d}^{-1}\right)\end{array}$ & $\begin{array}{l}\mathrm{NH}_{4}{ }^{+} \text {immobilizatio } \\
\text { n rate }\left(\mathrm{mg} \mathrm{N} \mathrm{m}^{-2} \mathrm{~d}^{-1}\right)\end{array}$ & $\begin{array}{l}\text { Microbial C } \\
\left(\mathrm{mg} \mathrm{C} \mathrm{m}^{-2}\right)\end{array}$ & $\begin{array}{c}\text { Microbial } \\
\left(\mathrm{mg} \mathrm{N} \mathrm{m}^{-2}\right)\end{array}$ & Microbial C:N \\
\hline \multirow[t]{4}{*}{ Sward composition } & & & $P=0.478$ & $P=0.367$ & $P=0.383$ & $P=0.970$ & $P=0.736$ & $P=0.348$ \\
\hline & control & 10 & $730( \pm 115)$ a & $92( \pm 26)$ a & $978( \pm 252)$ a & $50295( \pm 5707)$ а & $6870( \pm 999)$ a & $7.53( \pm 0.29) \mathrm{a}$ \\
\hline & dicot-enhanced & 10 & $530( \pm 114)$ a & $112( \pm 47)$ a & $665( \pm 133)$ a & $46428( \pm 4908)$ a & $5921( \pm 730)$ a & $8.03( \pm 0.21) \mathrm{a}$ \\
\hline & monocot-enh. & 10 & $570( \pm 113)$ a & $123( \pm 80)$ a & $640( \pm 119)$ a & $48190( \pm 3454)$ a & $6263( \pm 548)$ a & $7.84( \pm 0.33) \mathrm{a}$ \\
\hline \multirow[t]{3}{*}{ Fertilization } & & & $P=0.513$ & $P=0.009$ & $P=0.070$ & $P=0.203$ & $P=0.088$ & $P=0.386$ \\
\hline & no & 15 & $654( \pm 93)$ a & $48( \pm 9) b$ & $891( \pm 133)$ a & $51819( \pm 2875)$ a & $6797( \pm 375)$ a & $7.65( \pm 0.18) \mathrm{a}$ \\
\hline & NPK & 15 & $554( \pm 94)$ a & $204( \pm 66)$ a & $494( \pm 95) b$ & $44789( \pm 4441)$ a & $5906( \pm 798) b$ & $7.94( \pm 0.27)$ a \\
\hline Sward composition x Fertilization & & & $P=0.774$ & $P=0.504$ & $P=0.735$ & $P=0.103$ & $P=0.097$ & $P=0.093$ \\
\hline control & no & 5 & $824( \pm 170)$ & $77( \pm 25)$ & $1178( \pm 311)$ & $47798( \pm 3717)$ & $6104( \pm 226)$ & $7.82( \pm 0.48)$ \\
\hline control & NPK & 5 & $612( \pm 151)$ & $112( \pm 55)$ & $478( \pm 125)$ & $52791( \pm 11354)$ & $7637( \pm 2030)$ & $7.24( \pm 0.34)$ \\
\hline dicot-enhanced & no & 5 & $584( \pm 168)$ & $49( \pm 8)$ & $788( \pm 180)$ & $52465( \pm 6236)$ & $6732( \pm 861)$ & $7.85( \pm 0.20)$ \\
\hline dicot-enhanced & NPK & 5 & $477( \pm 167)$ & $190( \pm 88)$ & $512( \pm 197)$ & $40391( \pm 7128)$ & $5109( \pm 1148)$ & $8.20( \pm 0.38)$ \\
\hline monocot-enhanced & no & 5 & $554( \pm 146)$ & $24( \pm 7)$ & $707( \pm 160)$ & $55194( \pm 5166)$ & $7555( \pm 643)$ & $7.29( \pm 0.07)$ \\
\hline monocot-enhanced & NPK & 5 & $586( \pm 189)$ & $368( \pm 224)$ & $473( \pm 50)$ & $41185( \pm 1508)$ & $4972( \pm 314)$ & $8.40( \pm 0.56)$ \\
\hline
\end{tabular}

Mean values with different letter indicate significant $(P \leqq 0.05)$ or marginally significant $(P \leqq 0.1)$ differences within main factors (two-way ANOVA).

Average measured bulk density of $0.79 \mathrm{~g} \mathrm{~cm}^{-3}$ and a depth from $0.00-0.05 \mathrm{~m}$ was used to convert determined dry mass based rates to area based rates. 


\subsubsection{Water balance and $\mathrm{N}$ losses}

During the experiment, total annual precipitation was $1001 \mathrm{~mm}$ in 2009 and $1083 \mathrm{~mm}$ in 2010. Modelled annual evapotranspiration was $507 \mathrm{~mm}$ in 2009 and $484 \mathrm{~mm}$ in 2010. Modelled drainage flux was $441 \mathrm{~mm}$ in 2009 and $609 \mathrm{~mm}$ in 2010. At all three depths measured matrix potential was correlated with modelled matrix potential ( $0.2 \mathrm{~m}$ : Spearman's correlation coefficient $=0.66, P=0.001, \mathrm{n}=20 ; 0.5 \mathrm{~m}$ : Spearman's correlation coefficient $=$ 0.58, $P=0.007, \mathrm{n}=20 ; 0.9 \mathrm{~m}$ : Spearman's correlation coefficient $=0.745, P=0.018, \mathrm{n}=10$ ). In both years, modelled drainage flux was negligible in the summer months and strongly increased to values of more than $3 \mathrm{~mm} \mathrm{~d}^{-1}$ in autumn. In 2010, the increase in drainage flux occurred about one month earlier compared to 2009 (data not shown). Parallel to drainage flux, $\mathrm{NO}_{3}{ }^{-}$leaching losses were also negligible in the summer months (Fig. 4a, b, c). In fertilized plots, $\mathrm{NO}_{3}{ }^{-}$leaching strongly increased during autumn. Compared to 2009, when the main peak in $\mathrm{NO}_{3}{ }^{-}$leaching appeared only in early 2010, the increase in $\mathrm{NO}_{3}{ }^{-}$leaching following fertilization in 2010 was more pronounced and much earlier. In 2009, fertilization was the only factor that influenced $\mathrm{NO}_{3}{ }^{-}$leaching $(P=0.026)$. In $2010, \mathrm{NO}_{3}{ }^{-}$leaching losses strongly increased to a range of 0 to $281 \mathrm{mg} \mathrm{NO}_{3}{ }^{-}-\mathrm{N} \mathrm{m}^{-2} \mathrm{~d}^{-1}$ with an overall mean of $5.3( \pm$ $0.88 \mathrm{SE}) \mathrm{mg} \mathrm{NO}_{3}{ }^{-} \mathrm{N} \mathrm{m}^{-2} \mathrm{~d}^{-1}$. Fertilization $(P=0.000)$ and mowing frequency $(P=0.033)$ significantly influenced $\mathrm{NO}_{3}{ }^{-}$leaching. An interaction $(P=0.011)$ between these factors showed that the increase of $\mathrm{NO}_{3}{ }^{-}$leaching losses caused by fertilization was only significant for plots cut once per year while plots cut three times per year were not affected. Sward composition did not affect $\mathrm{NO}_{3}{ }^{-}$leaching.

Leaching of DON ranged between 0 to $1.9 \mathrm{mg} \mathrm{N} \mathrm{m}^{-2} \mathrm{~d}^{-1}$ with an overall mean of 0.26 ( $\pm 0.01 \mathrm{SE}$ ) $\mathrm{mg} \mathrm{N} \mathrm{m}^{-2} \mathrm{~d}^{-1}$ in 2009. None of the treatment factors influenced DON leaching (Fig. 4d, e, f). In 2010, DON leaching increased to an overall mean of 0.6 ( $\pm 0.1 \mathrm{SE}) \mathrm{mg} \mathrm{N} \mathrm{m}^{-}$ ${ }^{2} \mathrm{~d}^{-1}$ ranging from 0 to $13.06 \mathrm{mg} \mathrm{N} \mathrm{m}^{-2} \mathrm{~d}^{-1}$. We detected an interaction between the factors fertilization and mowing frequency $(P=0.006)$ : on the plots cut once per year, fertilization significantly increased DON leaching while plots cut three times per year were not affected. No effect of sward composition on DON leaching could be detected. 


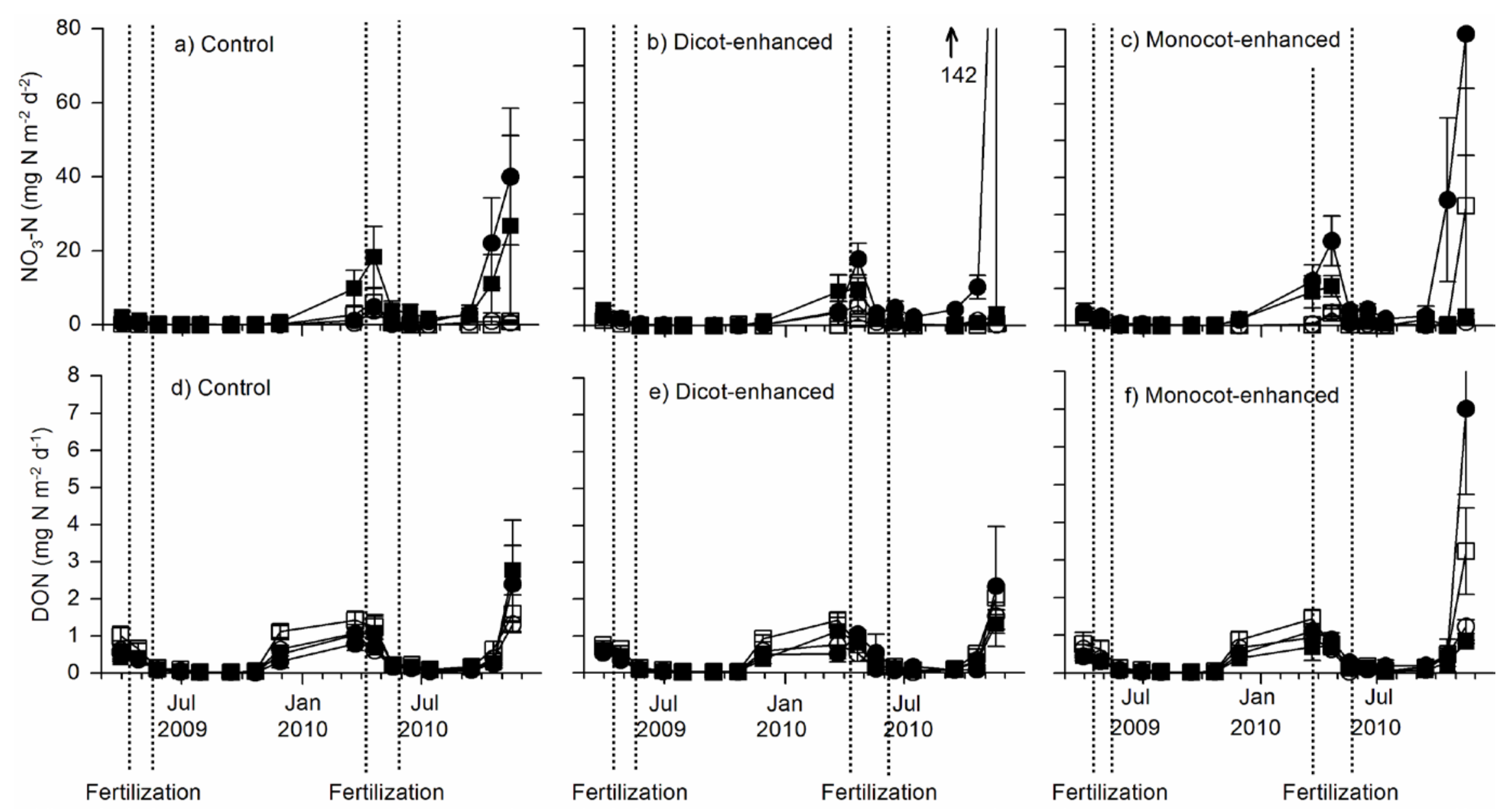

Figure 4: $\mathrm{NO}_{3}{ }^{-}$and DON leaching rates $( \pm \mathrm{SE}, \mathrm{n}=6)$ at 0.5-0.6 m mineral soil of a grassland under different management practices in the Solling uplands, Germany: one mowing per year without fertilization $(\odot)$, one mowing per year with fertilization $(\bullet)$, three mowings per year without fertilization ( $\square$ ), three mowings per year with fertilization $(\mathbf{\square})$. 
In 2009, $\mathrm{N}_{2} \mathrm{O}$ emission rates varied between -3.87 to $8.07 \mathrm{mg} \mathrm{N}_{2} \mathrm{O}-\mathrm{N} \mathrm{m}^{-2} \mathrm{~d}^{-1}$ with an overall mean of $0.32( \pm 0.04 \mathrm{SE}) \mathrm{mg} \mathrm{N}_{2} \mathrm{O}-\mathrm{N} \mathrm{m}^{-2} \mathrm{~d}^{-1}$. Both fertilization $(P=0.000)$ and mowing frequency $\left(P=0.031\right.$ ) influenced $\mathrm{N}_{2} \mathrm{O}$ emissions in 2009 (Fig. 5a, b, c). Furthermore there was an interaction between these factors $(P=0.009)$. Fertilized plots showed an increase in $\mathrm{N}_{2} \mathrm{O}$ fluxes, especially following the second fertilizer application in May. However this increase was only significant for the plots cut once per year. Unfertilized plots only showed a marginal increase in $\mathrm{N}_{2} \mathrm{O}$ fluxes during the summer months. In 2010, the significant effect of fertilization ( $P=0.000$ ) could also be observed (Fig. 5d, e, $\mathrm{f}$ ) with an overall mean of 0.45 ( $\pm 0.06 \mathrm{SE}$ ) mg $\mathrm{N}_{2} \mathrm{O}-\mathrm{N} \mathrm{m}^{-2} \mathrm{~d}^{-1}$ (range between -1.84 to $13.58 \mathrm{mg} \mathrm{N}_{2} \mathrm{O}-\mathrm{N} \mathrm{m}^{-2} \mathrm{~d}^{-1}$ ). Again, the increase of $\mathrm{N}_{2} \mathrm{O}$ emissions occurred after the second fertilization in the beginning of July and the impact of fertilization tended to be stronger on the plots cut once per year, however, unlike 2009, this interaction was not significant $(P=0.108)$. In both years, $\mathrm{N}_{2} \mathrm{O}$ uptake predominantly occurred on unfertilized plots. There was no impact of sward composition on $\mathrm{N}_{2} \mathrm{O}$ emissions. 


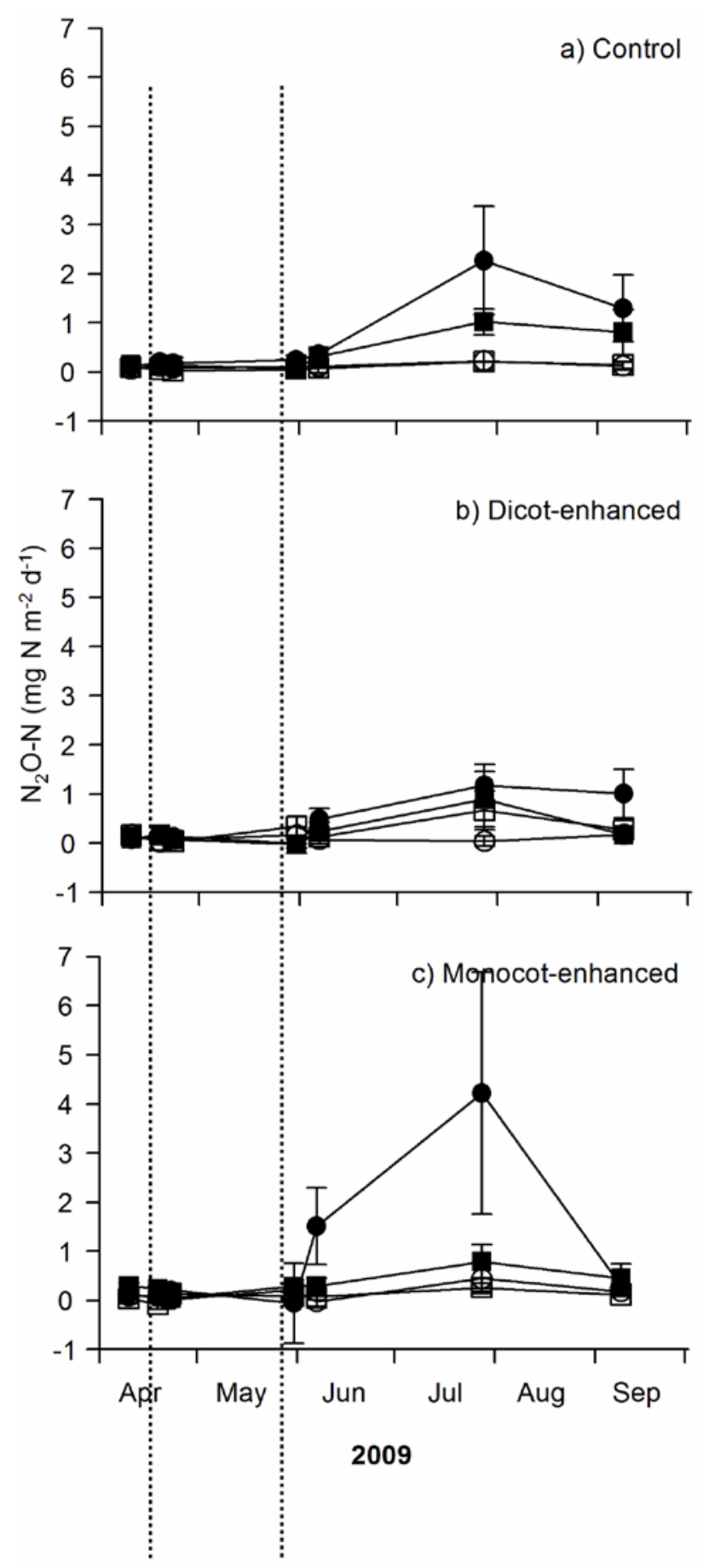

Fertilization

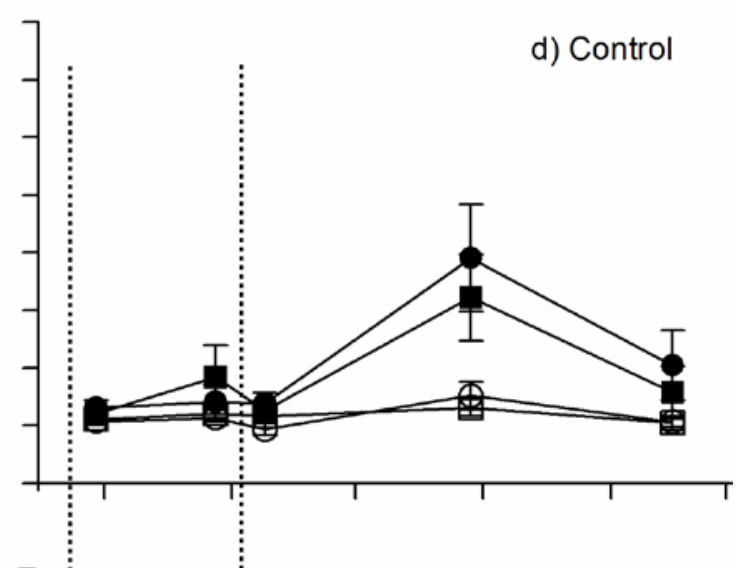

e) Dicot-enhanced

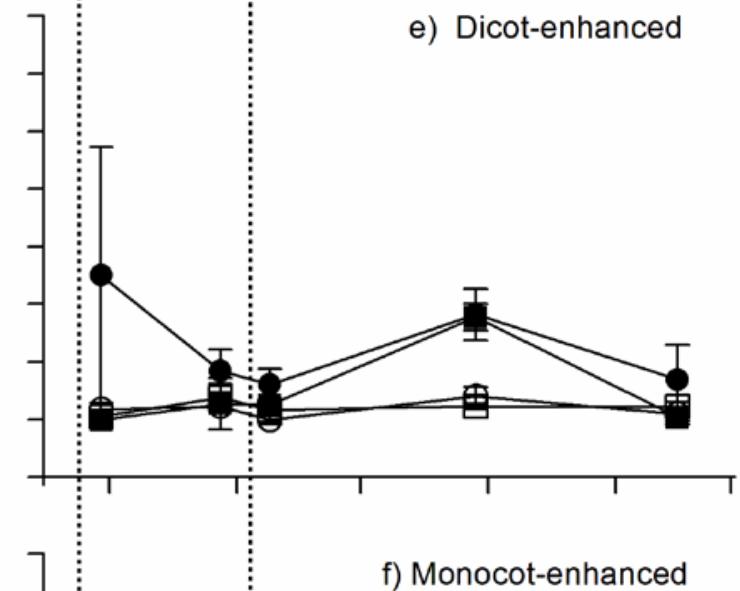

f) Monocot-enhanced

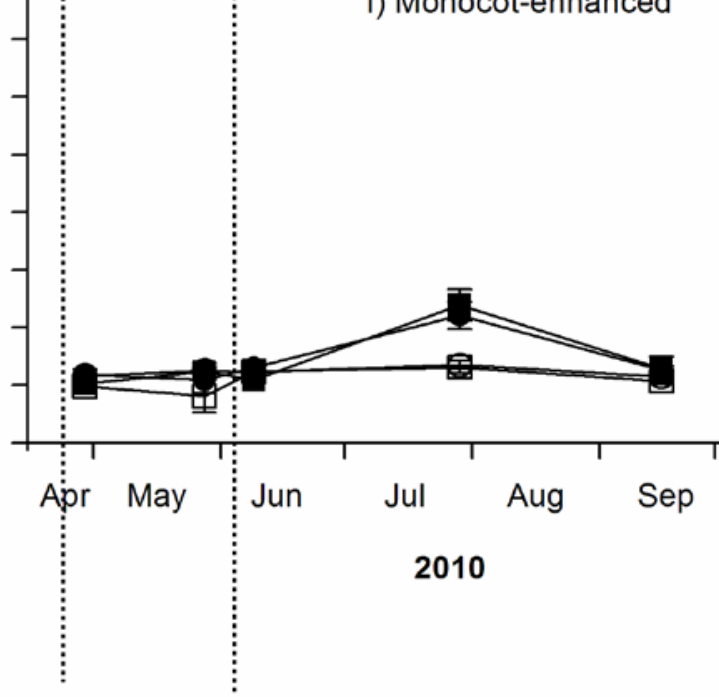

Fertilization

Figure 5: $\mathrm{N}_{2} \mathrm{O}$ emissions $( \pm \mathrm{SE}, \mathrm{n}=6$ ) of a grassland under different management practices in the Solling uplands, Germany: one mowing per year without fertilization $(\circ)$, one mowing per year with fertilization $(\bullet)$, three mowings per year without fertilization $(\square)$, three mowings per year with fertilization $(\mathbf{\square})$. 


\subsubsection{N retention efficiency}

We calculated $N$ retention efficiency only for 2010 which ranged from 0.842 to 0.999 with an overall mean of $0.976( \pm 0.017 \mathrm{SE})$. Fertilization decreased $\mathrm{N}$ retention efficiency $(P=0.003)$ and was the most important factor, explaining 22\% of the variance (Table 9). Sward composition explained $17 \%$ of the variance $(P=0.048)$ with the highest $\mathrm{N}$ retention efficiency in the control sward followed by the dicot-enhanced sward and the monocotenhanced sward. Only the difference between control and monocot-enhanced sward was significant. Across all treatments, $\mathrm{N}$ retention efficiency was correlated with $\mathrm{NH}_{4}{ }^{+}$ immobilization and microbial N (Table 10). Furthermore, there were marginally significant correlations with microbial $\mathrm{C}$ and plant $\mathrm{N}$ uptake but not with harvested biomass. 
Table 9: N retention efficiency of a grassland under different management practices in the Solling uplands, Germany.

\begin{tabular}{|c|c|c|c|c|c|c|}
\hline Main factors & Treatments & $\mathrm{n}$ & $\begin{array}{c}\text { N retention efficiency } \\
{\left[1-\left(\mathrm{mg} \mathrm{N} \text { losses } \mathrm{m}^{-2} \mathrm{~d}^{-1} /\right.\right.} \\
\left.\left.\text { mg gross } \mathrm{N} \text { mineralization } \mathrm{m}^{-2} \mathrm{~d}^{-1}\right)\right]\end{array}$ & $\mathrm{SE}$ & $P$ & $\begin{array}{l}\text { Variance } \\
\text { explained } \\
\text { (\%) }\end{array}$ \\
\hline \multirow[t]{4}{*}{ Sward compos } & & & & & 0.046 & 16.69 \\
\hline & control & 12 & 0.991 a & 0.005 & & \\
\hline & monocot-enhanced & 12 & $0.963 \mathrm{~b}$ & 0.016 & & \\
\hline & dicot-enhanced & 12 & $0.981 \mathrm{ab}$ & 0.005 & & \\
\hline \multirow[t]{3}{*}{ Fertilization } & & & & & 0.007 & 22.06 \\
\hline & no & 18 & 0.995 a & 0.002 & & \\
\hline & NPK & 18 & $0.960 \mathrm{~b}$ & 0.011 & & \\
\hline
\end{tabular}

Mean values with different letter indicate significant differences among treatments within main factors (two-way ANOVA with Tukey HSD at $\mathrm{P} \leqq 0.05$ )

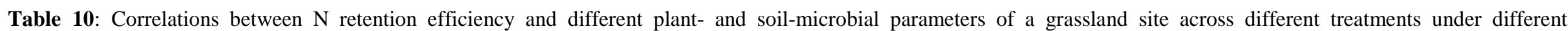
management practices in the Solling uplands, Germany (Spearman's rank correlation).

\begin{tabular}{lcc}
\hline Parameter & Spearman's rho & $P$ \\
\hline Plant N uptake * & 0.338 & 0.074 \\
Harvested biomass * & -0.031 & 0.871 \\
$\mathrm{NH}_{4}{ }^{+}$immobilization & 0.560 & 0.006 \\
Microbial C & 0.364 & 0.053 \\
Microbial N & 0.417 & 0.025
\end{tabular}

* Plant N uptake was reported by Keuter et al. (2012) and harvested biomass was reported by From et al. (2011) 


\subsection{Discussion}

\subsubsection{Gross $\mathbf{N}$ mineralization rates, immobilization rates and microbial biomass}

Gross $\mathrm{N}$ mineralization rates in this study were considerably higher than the range reported for temperate grasslands (300 to $410 \mathrm{mg} \mathrm{N} \mathrm{m}^{-2} \mathrm{~d}^{-1}$ ) in Northeastern USA (Corre et al. 2002) and in the UK (Jamieson et al. 1999; Ledgard et al. 1998). Also our $\mathrm{NH}_{4}{ }^{+}$immobilization rates exceeded the rates of total gross $\mathrm{N}$ immobilization measured by Ledgard et al. (1998) who reported values between 0.21 and $1.63 \mu \mathrm{g} \mathrm{N} \mathrm{g}^{-1} \mathrm{~d}^{-1}$. Net immobilization of mineral $\mathrm{N}$ as we observed on the unfertilized plots has also been reported in other studies conducted on temperate permanent grassland (e.g. Accoe et al. 2004) and may be explained by a stimulation of $\mathrm{NH}_{4}{ }^{+}$consumption due to the addition of the substrate $\left(\mathrm{NH}_{4}{ }^{+}\right)$since this process is measured by ${ }^{15} \mathrm{~N}$ tracing and not by ${ }^{15} \mathrm{~N}$ isotope dilution (Accoe et al. 2004).

The lower $\mathrm{NH}_{4}{ }^{+}$immobilization rates at the fertilized plots demonstrate that fertilization did not only affect $\mathrm{N}$ losses directly, but also indirectly through a decrease in microbial immobilization of $\mathrm{NH}_{4}{ }^{+}$. A negative effect of mineral fertilization on microbial $\mathrm{N}$ immobilization was also reported by Ledgard et al. (1998). Furthermore, in an experiment where $\mathrm{N}$ deposition was reduced in a spruce stand close to our site, an increase in $\mathrm{NH}_{4}{ }^{+}$ immobilization and a higher microbial N pool were reported (Corre and Lamersdorf 2004). Addition of $\mathrm{N}$ to the soil can cause changes in chemical bond structures of soil organic matter (Berg and Matzer 1997) which may in turn, reduce the effectiveness of extracellular catabolic enzymes. Furthermore, $\mathrm{N}$ addition may also lead to a decrease in the production of humusdegrading enzymes (e.g. Tien and Myer 1990). Since we detected no differences in microbial $\mathrm{C}$ and gross $\mathrm{N}$ mineralization between fertilization treatments the lower $\mathrm{NH}_{4}{ }^{+}$immobilization rates may also be caused by lower $\mathrm{C}: \mathrm{N}$ ratios of the decomposed substrate on the fertilized plots (Keuter et al. 2012). Finally, the lower $\mathrm{NH}_{4}{ }^{+}$immobilization may be related to lower amounts of $\mathrm{N}$ required for maintenance of the microbial biomass (as can e.g. be caused by a change in microbial community from bacteria towards fungi). The observed interaction between sward composition and fertilization in microbial biomass $\mathrm{N}$ and the microbial C:N ratios would also point in this direction. 


\subsubsection{N losses}

In 2009, the average rate of $\mathrm{NO}_{3}{ }^{-}$leaching was very low compared to other studies on temperate fertilized grassland. The strong increase in $\mathrm{NO}_{3}{ }^{-}$leaching in 2010 was mainly due to the higher $\mathrm{NO}_{3}{ }^{-}$concentration in the leachate, which was caused by the delayed $\mathrm{NO}_{3}{ }^{-}$ leaching peak in early 2010, following fertilization in 2009. While in 2009, the grassland may have been somewhat more effective in retaining the fertilized $N$ than in 2010 (shown e.g. by the higher biomass production and plant N uptake in 2009, compared to 2010; Keuter et al. 2012), the different amounts and distribution of precipitation was probably the main cause of the different timing of the $\mathrm{NO}_{3}{ }^{-}$leaching peaks in both years. Accumulation of fertilizer $\mathrm{N}$ was also observed by Baker and Johnson (1981) who reported high $\mathrm{NO}_{3}{ }^{-}$concentrations in tile drainage three years after fertilization. Similar $\mathrm{NO}_{3}{ }^{-}$concentrations in leachate of $>60 \mathrm{mg}$ $\mathrm{NO}_{3}-\mathrm{N} \mathrm{L}^{-1}$ have been reported under Miscanthus grass fertilized with $120 \mathrm{~kg} \mathrm{~N} \mathrm{yr}^{-1}$ (Christian and Riche 1998). In our study, DON leaching rates were an order of magnitude lower than $\mathrm{NO}_{3}{ }^{-}$leaching rates and were low compared to values reported from several agricultural studies which range from 0.3 to $127 \mathrm{~kg} D O N ~ h a^{-1} \mathrm{yr}^{-1}$ and account for $26 \%$ of the total soluble $\mathrm{N}$ (van Kessel et al. 2009). These low DON leaching rates may be related to the relatively low abundance of legumes, the exclusive use of mineral fertilizer, the exclusion of grazing and the fine-textured soil at our site (van Kessel et al. 2009). Also our measured $\mathrm{N}_{2} \mathrm{O}$ fluxes were low compared to other studies conducted in grasslands. Flechard et al. (2005) reported emission rates between -6 and $24 \mathrm{~N}_{2} \mathrm{O}-\mathrm{N} \mathrm{mg} \mathrm{m}^{-2} \mathrm{~d}^{-1}$ for unfertilized grasslands and between -6 and 132 $\mathrm{N}_{2} \mathrm{O}-\mathrm{N} \mathrm{mg} \mathrm{m}{ }^{-2} \mathrm{~d}^{-1}$ for grasslands fertilized with $200 \mathrm{~kg} \mathrm{~N} \mathrm{ha}^{-1} \mathrm{yr}^{-1}$ in Switzerland. Also Jones et al. (2005) determined $\mathrm{N}_{2} \mathrm{O}$ peaks of up to $34 \mathrm{~N}_{2} \mathrm{O}-\mathrm{N} \mathrm{mg} \mathrm{m} \mathrm{m}^{-2} \mathrm{~d}^{-1}$ on a grassland site in southern Scottland fertilized with $300 \mathrm{~kg} \mathrm{~N} \mathrm{ha}^{-1} \mathrm{yr}^{-1}$.

The observed higher $\mathrm{N}$ losses following fertilizer application, independent of the pathway $\left(\mathrm{NO}_{3}^{-}\right.$leaching, DON leaching and $\mathrm{N}_{2} \mathrm{O}$ emissions) is in line with our first hypothesis. Similar findings have been reported in studies on $\mathrm{NO}_{3}{ }^{-}$leaching (e.g. Christian and Riche 1998) in studies on DON leaching (Dijkstra et al. 2007; Fang et al. 2009) and in studies reporting $\mathrm{N}_{2} \mathrm{O}$ fluxes (e.g. Jones et al. 2005). Our finding that increasing mowing frequency can decrease leaching of $\mathrm{NO}_{3}{ }^{-}$and DON and reduce $\mathrm{N}_{2} \mathrm{O}$ emissions on the fertilized plots is at least partly in line with our second hypothesis that mowing reduces $\mathrm{N}$ losses. A decrease of $\mathrm{N}_{2} \mathrm{O}$ emissions with increasing mowing frequency was also reported for a German grassland site, which was interpreted as a result of a higher plant $\mathrm{N}$ uptake and thus lower denitrification and nitrification rates (Kammann et al. 1998). A study by our group, conducted on the same location also showed an increase of $\mathrm{N}$ response efficiency, $\mathrm{N}$ uptake 
efficiency and plant $\mathrm{N}$ uptake with increasing mowing frequency (Keuter et al. 2012). This may be caused by a higher resource allocation to shoots following defoliation resulting in an overcompensatory regrowth (Guitian and Bardgett 2000). However, microbial immobilization may also contribute to the influence of mowing since defoliation of plants can increase rhizodeposition (Holland et al. 1996). More frequent mowing may thus stimulate C input from plants which in turn may cause higher microbial $\mathrm{N}$ immobilization. A higher soil microbial biomass as a result of defoliation of grasses was also observed by Guitian and Bardgett (2000).

We observed no effect of sward composition on $\mathrm{NO}_{3}{ }^{-}$and DON leaching and on $\mathrm{N}_{2} \mathrm{O}$ emissions which appears to be in contrast with some other studies. Differences in soil extractable $\mathrm{N}$ caused by plant diversity or plant functional groups have been reported, however, diversity effects on $\mathrm{NO}_{3}{ }^{-}$and DON leaching are more ambiguous. Hooper and Vitousek (1998) did not observe plant diversity effects on $\mathrm{NO}_{3}{ }^{-}$leaching whereas a study in a semi-natural mid-European grassland ecosystem observed a decrease of the total annual loss of $\mathrm{NO}_{3}{ }^{-}$with increasing plant functional group richness (Scherer-Lorenzen et al. 2003). However, this effect was only significant for communities containing legumes and may thus have been an effect of reduction in legume abundance rather than an effect of species richness per se (Scherer-Lorenzen et al. 2003). In contrast, significant decreases in mineral and DON leaching rates with increasing biodiversity were reported for planted grassland plots in Minnesota, USA (Dijkstra et al. 2007). This was explained by a higher productivity and consequently higher organic $\mathrm{N}$ pools, higher microbial activity and higher DON production at higher levels of species richness. The study of Dijkstra et al. (2007) had strongly contrasting levels of species richness (1 versus 16 species) while the number of species in our treatments were at relatively high levels with relatively small differences. Reviews have shown that diversity effects are most pronounced in the range of one to five species (Wrage et al. 2011). This makes it unlikely that in our study we were able to detect any diversity effects. Also in an earlier study of our group conducted in another farm in the Solling area, we did not observe an effect of plant diversity on $\mathrm{N}_{2} \mathrm{O}$ and $\mathrm{NO}$ emissions (Hoeft et al. 2012).

\subsubsection{N retention efficiency}

As hypothesized, $\mathrm{N}$ retention efficiency was lower on the fertilized compared to unfertilized plots. This fertilization effect was caused by higher $\mathrm{N}$ losses rather than changes in gross $\mathrm{N}$ mineralization rates which did not change significantly. In our previous study, we were able to demonstrate that fertilized plots had higher $\mathrm{N}$ uptake but lower $\mathrm{N}$ uptake efficiency (i.e. the 
proportion of plant available $\mathrm{N}$ that is taken up by plants) (Keuter et al. 2012). In the present study we only determined $\mathrm{N}$ retention efficiency for plots cut once per year where fertilization did not affect $\mathrm{N}$ uptake efficiency (data not shown). This suggests that differences in $\mathrm{N}$ losses between fertilized and unfertilized plots were caused by differences in microbial immobilization rather than differences in plant $\mathrm{N}$ uptake efficiency.

Apart from fertilization, sward composition also affected $\mathrm{N}$ retention efficiency. The untreated control sward had the highest $\mathrm{N}$ retention efficiency which was in contrast to our hypothesis. In our earlier study, we also found higher $\mathrm{N}$ response efficiency and marginally higher $\mathrm{N}$ uptake efficiency for the control sward compared to the other treatments (Keuter et al. 2012). The control sward is the result of decades of extensive management practices and $\mathrm{N}$ limited conditions and the sward probably developed towards a composition that is most efficient in $\mathrm{N}$ retention efficiency. The dicot-enhanced swards did not differ in $\mathrm{N}$ retention efficiency from the control or the monocot-enhanced swards, while the plant $\mathrm{N}$ uptake efficiency was slightly higher at the monocot-enhanced swards than the dicot-enhanced swards (Keuter et al. 2012). We suggest that this can be explained by differences in microbial $\mathrm{NH}_{4}{ }^{+}$immobilization which mirrored the differences in $\mathrm{N}$ retention efficiency (control sward $\geq$ dicot-enhanced sward $\geq$ monocot enhanced sward) The correlations between microbial biomass $\mathrm{N}$ and $\mathrm{NH}_{4}{ }^{+}$immobilization and the lack of correlations with plant $\mathrm{N}$ uptake and harvested biomass also suggest that the microbial community rather than sward composition was responsible for the observed differences in $\mathrm{N}$ retention efficiency (Table 10). This supports the studies of Hooper and Vitousek $(1997,1998)$ who showed that microbial N uptake may be a more important pathway for $\mathrm{N}$ retention than plant $\mathrm{N}$ uptake and that indirect plant effects through microbial immobilization may equal or even exceed direct plant uptake effects on nutrient retention.

\subsection{Conclusions}

Fertilizer application was the dominant factor influencing $\mathrm{N}$ losses and $\mathrm{N}$ retention efficiency which was strongly influenced by microbial $\mathrm{NH}_{4}{ }^{+}$immobilization. Our results also show that intensive mowing can partly reduce the high $\mathrm{N}$ losses following $\mathrm{N}$ fertilization. We furthermore found indications that control swards that have developed under decades of extensive grassland management have the highest efficiency in $\mathrm{N}$ retention. This high $\mathrm{N}$ retention efficiency was partly caused by a complementary use of resources but was also the result of differences in microbial $\mathrm{NH}_{4}{ }^{+}$immobilization. $\mathrm{N}$ retention efficiency responded to variations in sward composition which was not the case with $\mathrm{N}$ losses, showing that $\mathrm{N}$ 
retention efficiency was a more sensitive index. Furthermore, our study underlines the importance of microbial immobilization for the retention of $\mathrm{N}$ in the plant-soil system. In contrast to other more commonly used indices like $\mathrm{N}$ response efficiency and $\mathrm{N}$ uptake efficiency, $\mathrm{N}$ retention efficiency considers microbial immobilization as a pathway for $\mathrm{N}$ retention in the plant-soil system which is a critical factor to consider when evaluating the sustainability of grasslands.

\section{Acknowledgements}

This work is part of the Cluster of Excellence 'Functional Biodiversity Research' and has been funded by the State of Lower Saxony, the Ministry of Science and Culture and the Niedersächsisches Vorab. The authors thank D. Boettger, N. C. Meyer, C. Gottwald, A. Baldos and J. Sueta for support with experimental set up and field measurements. We thank I. Ostermeyer for the soil texture analysis and the technical assistants of the BüsgenInstitute and the Department of Plant Ecology for soil analyses. We thank C. Scherber and Y. Clough for their support with the statistics. 


\section{References}

Aber J, McDowell W, Nadelhoffer K, et al. (1998): Nitrogen saturation in temperate forest ecosystems. Bioscience 48: 921-934.

Accoe F, Boeckx P, Buschaert J, Hofman G, and van Cleemput O (2004): Gross N transformation and net N mineralization rates related to the $\mathrm{C}$ and $\mathrm{N}$ contents of soil organic matter fractions in grassland soils of different age. Soil Biology Biochemistry 36: 2075-2087.

Baker JL and Johnson HP (1981): Nitrate-nitrogen in tile drainage as affected by fertilization. Journal of Environmental Quality 10: 519-522.

Berg B and Matzner E (1997): Effect of $N$ deposition on decomposition of plant litter and soil organic matter in forest systems. Environmental Reviews 5: 1-25.

Blake GR and Hartge KH (1986): Bulk density. In: Klute A (ed) Methods of soil analysis: Part 1 - Physical and mineralogical methods. Wisconsion: Soil Science Society of America, pp 363-375.

Bristow AW, Ryden JC, and Whitehead DC (1987): The fate at several time intervals of ${ }^{15} \mathrm{~N}$-labelled ammonium nitrate applied to an established grass sward. Journal of Soil Science 38: 245-254.

Brookes PC, Landman A, Pruden G, Jenkinson DS (1985): Chloroform fumigation and the release of soil nitrogen: A rapid direct extraction method to measure microbial biomass nitrogen in soil. Soil Biology and Biochemistry 17: 837-842.

Christian DG and Riche AB (1998): Nitrate leaching losses under Miscanthus grass planted on a silty clay loam soil. Soil Use and Management 14: 131-135.

Clapp RB and Hornberger GM (1978): Empirical equations for some soil hydraulic-properties. Water Resources Research 14: 601-604.

Corre MD, Schnabel RR, and Stout WL (2002): Spatial and seasonal variation of gross nitrogen transformations and microbial biomass in a Northeastern US grassland. Soil Biology and Biochemistry 34: 445-457.

Corre MD and Lamersdorf NP (2004): Reversal of nitrogen saturation after long-term deposition reduction: Impact on soil nitrogen cycling. Ecology 85: 3090-3104.

Corre MD, Brumme R, Veldkamp E, and Beese FO (2007): Changes in nitrogen cycling and retention processes in soils under spruce forests along a nitrogen enrichment gradient in Germany. Global Change Biology 13: 1509-1527.

Crawley MJ (2007): The R book. John Wiley \& Sons Ltd, Chichester, West Sussex.

Davidson EA, Hart SC, Shanks CA, and Firestone MK (1991): Measuring gross nitrogen mineralization, immobilization, and nitrification by ${ }^{15} \mathrm{~N}$ isotopic pool dilution in intact soil cores. Journal of Soil Science 42: 335-349.

Di HJ and Cameron KC (2002): Nitrate leaching in temperate agroecosystems: sources, factors and mitigating strategies. Nutrient Cycling in Agroecosystems 64: 237-256.

Dijkstra FA, West JB, Hobbie SE, Reich PB, and Trost J (2007): Plant diversity, $\mathrm{CO}_{2}$, and N influence inorganic and organic $\mathrm{N}$ leaching in grasslands. Ecology 88: 490-500.

Ewel JJ, Mazzarino MJ, and Berish CW (1991): Tropical soil fertility changes under monocultures and successional communities of different structure. Ecology Applications 1: 289-302.

Fang Y, Zhu W, Gundersen P, Mo J, Zhou G, and Yoh M (2009): Large loss of dissolved organic nitrogen from nitrogen-saturated forests in subtropical China. Ecosystems 12: 33-45. 
Federer CA, Vorosmarty C, and Fekete B (2003): Sensitivity of annual evaporation to soil and root properties in two models of contrasting complexity. Journal of Hydrometeorology 4: 1276-1290.

Ferraro DO and Oesterheld M (2002): Effect of defoliation on grass growth. A quantitative review. Oikos 98: 125-133.

Flechard CR, Neftel A, Jocher M, Ammann C, and Fuhrer J (2005): Bi-directional soil/atmosphere $\mathrm{N}_{2} \mathrm{O}$ exchange over two mown grassland systems with contrasting management practices. Global Change Biology 11: 2114-2127.

Galloway JN, Townsend AR, Erisman JW, et al. (2008): Transformation of the nitrogen cycle: Recent trends, questions, and potential solutions. Science 320: 889-892.

Guitian R and Bardgett RD (2000): Plant and soil microbial responses to defoliation in temperate semi-natural grassland. Plant and Soil 220: 271-277.

Hoeft I, Steude K, Wrage N, and Veldkamp E (2012): Response of nitrogen oxide emissions to grazer species and plant species composition in temperate agricultural grassland. Agriculture, Ecosystems and Environment 151: 34-43.

Holland JN, Cheng W, and Crossley DA (1996): Herbivore-induced changes in plant carbon allocation: Assessment of below-ground C fluxes using carbon-14. Oecologia 107: 87-94.

Hooper DU and Vitousek PM (1997): The effects of plant composition and diversity on ecosystem processes. Science 277: 1302-1305.

Hooper DU and Vitousek PM (1998): Effects of plant composition and diversity on nutrient cycling. Ecological Monographs 68: 121-149.

IUSS working group WRB (2006): World reference base for soil resources 2006. World soil resources reports No. 130. FAO, Rome.

Jackson LE, Schimel JP, and Firestone MK (1989): Short-term partioning of ammonium and nitrate between plants and microbes in an annual grassland. Soil Biology and Biochemistry 21: 409-415.

Jamieson N, Monaghan R, and Barraclough D (1999): Seasonal trends of gross N mineralization in a natural calcareous grassland. Global Change Biology 5: 423-431.

Joergensen RG (1996): The fumigation-extraction method to estimate soil microbial biomass: Calibration of the $K_{\mathrm{EC}}$ value. Soil Biology and Biochemistry 28: 25-31.

Jones SK, Rees RM, Skiba UM, and Ball BC (2005): Greenhouse gas emissions from a managed grassland. Global and Planetary Change 47: 201-211.

Kammann C, Grunhage L, Muller C, Jacobi S, and Jager HJ (1998): Seasonal variability and mitigation options for $\mathrm{N}_{2} \mathrm{O}$ emissions from differently managed grasslands. Environmental Pollution 102: 179-186.

Keuter A, Hoeft I, Veldkamp E, and Corre MD (2012): Nitrogen response efficiency of a managed and phytodiverse temperate grassland. Plant and Soil. DOI: 10.1007/s11104-012-1344-y.

Kirkham D and Bartholomew WV (1954): Equations for following nutrient transformation in soil, utilizing tracer data. Soil Science Society of America Journal 18: 33-34.

König N and Fortmann H (1996): Probenvorbereitungs-, Untersuchungs- und Elementbestimmungs- Methoden des Umweltanalytik-Labor der Niedersächsischen Forstlichen Versuchsanstalt und des Zentrallabor II des Forschungszentrums Waldökosysteme. Teil 1: Elementbestimmungsmethoden A-M. Berichte des Forschungszentrums Waldökosysteme der Universität Göttingen. 
Ledgard SF, Jarvis SC, and Hatch DJ ( 1998): Short-term nitrogen fluxes in grassland soils under different longterm nitrogen management regimes. Soil Biology and Biochemistry 30: 1233-1241.

Loftfield N, Flessa H, Augustin J, and Beese F (1997): Automated gas chromatographic system for rapid analysis of the atmospheric trace gases methane, carbon dioxide, and nitrous oxide. Journal of Environmental Quality 26: 560-564.

Niklaus PA, Kandeler E, Leadley PW, Schmid B, Tscherko D, and Korner C (2001): A link between plant diversity, elevated $\mathrm{CO}_{2}$ and soil nitrate. Oecologia 127: 540-548.

Petersen U, Wrage N, Köhler L, Leuschner C, and Isselstein J (2012): Manipulating the species composition of permanent grasslands - A new approach to biodiversity experiments. Basic and Applied Ecology 13: 1-9.

R Development Core Team (2009): R: A language and environment for statistical computing. R Foundation for Statistical Computing, Vienna, Austria.

Rose L, Coners H, and Leuschner C (2011): Effects of fertilization and cutting frequency on the water balance of a temperate grassland. Ecohydrology 5: 64-72.

Scherer-Lorenzen M, Palmborg C, Prinz A, and Schulze ED (2003): The role of plant diversity and composition for nitrate leaching in grasslands. Ecology 84: 1539-1552.

Schlesinger WH (2009): On the fate of anthropogenic nitrogen. Proceedings of the National Academy of Sciences 106: 203-208.

Shen SM, Pruden G, and Jenkinson DS (1984): Mineralization and immobilization of nitrogen in fumigated soil and the measurement of microbial biomass nitrogen. Soil Biology and Biochemistry 16: 437-444.

Shuttleworth WJ and Wallace JS (1985): Evaporation from sparse crops - an energy combination theory. Quarterly Journal of the Royal Meteorological Society 111: 839-855.

Tien M and Myer SB (1990): Selection and characterization of mutants of Phanerochaete chrysopsporum exhibiting ligninolytic activity under nutrient-rich conditions. Applied and Environmental Microbiology 56: $2540-2544$.

Tilman D, Wedin D, and Knops J (1996): Productivity and sustainability influenced by biodiversity in grassland ecosystems. Nature 379: 718-720.

van Kessel C, Clough T, van Groenigen JW (2009): Dissolved organic nitrogen: An overlooked pathway of nitrogen loss from agricultural systems? Journal of Environmental Quality 38: 393-401.

Vitousek PM and Howarth RW (1991): Nitrogen limitation on land and in the sea - How can it occur? Biogeochemistry 13: 87-115.

Wrage N, Strodthoff J, Cuchillo HM, Isselstein J, and Kayser M (2011): Phytodiversity of temperate permanent grasslands: ecosystem services for agriculture and livestock management for diversity conservation. Biodiversity and Conservation 20: 3317-3339.

Zuur AF, Ieno EN, Walker NJ, Saveliev AA, and Smith GM (2009): Mixed effects models and extensions in ecology with R, statistics for biology and health. New York: Springer Science + Business Media. 


\section{ASYMBIOTIC BIOLOGICAL NITROGEN FIXATION IN A TEMPERATE GRASSLAND UNDER DIFFERENT FERTILIZATION AND MOWING TREATMENTS}

Andreas Keuter, Edzo Veldkamp, Marife D. Corre

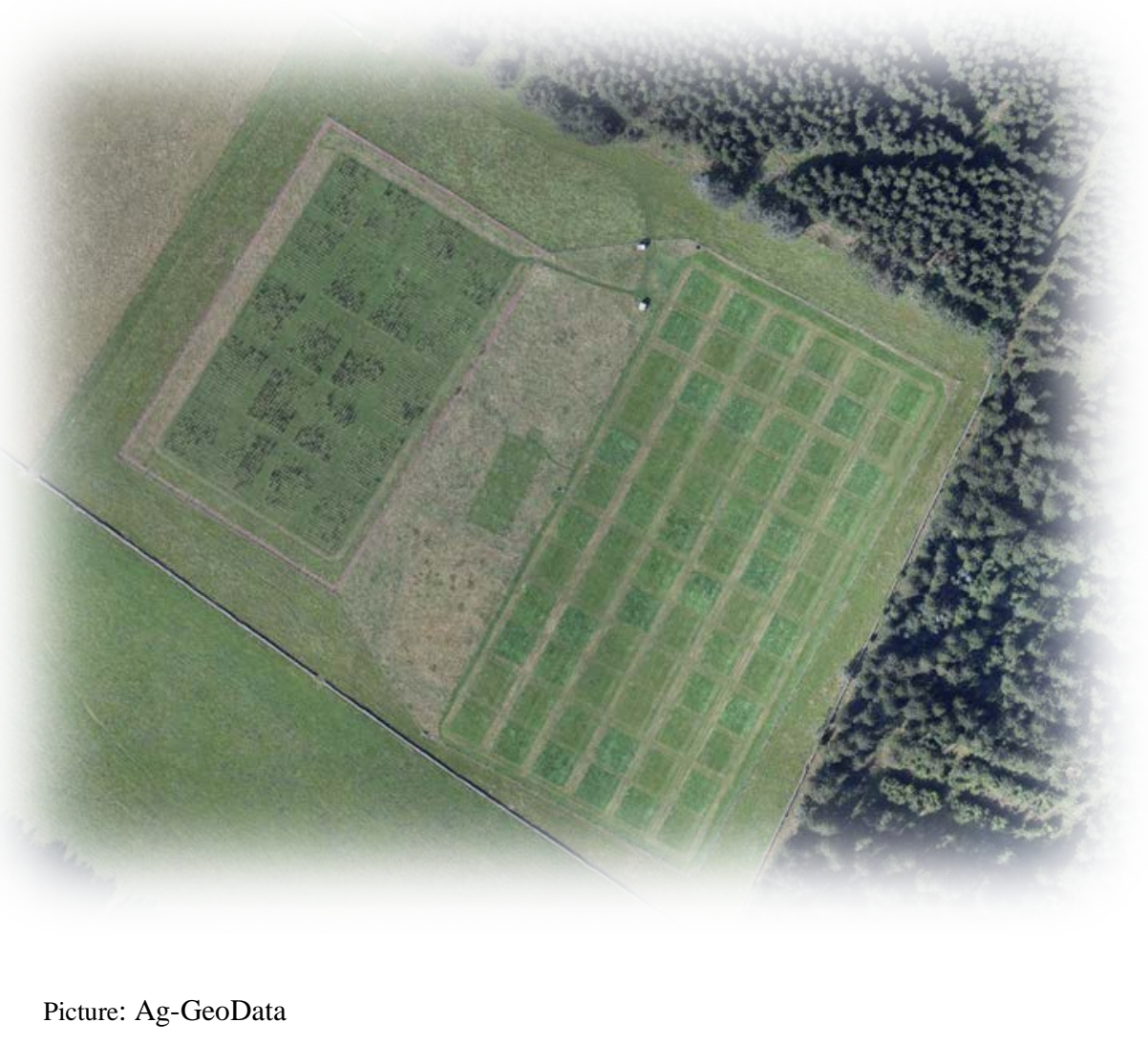




\begin{abstract}
Existing estimates of asymbiotic biological $\mathrm{N}$ fixation (BNF) are incomplete and spatially unresolved. Furthermore, it is unclear how BNF has changed from pre-industrial rates to present day rates where it is potentially influenced by agricultural management practices and atmospheric $\mathrm{N}$ deposition. We examined the effect of fertilization with nitrogen $(\mathrm{N})$ and phosphorus (P) and mowing frequency on asymbiotic BNF rates in a temperate managed grassland site. We measured asymbiotic BNF on intact soil cores incubated in the field and in the lab using the acetylene reduction assay, calibrated against direct measurements with ${ }^{15} \mathrm{~N}_{2}$ label. Our study suggests that asymbiotic BNF can provide significant N inputs between 1.5 and $4.9 \mathrm{~kg} \mathrm{ha}^{-1} \mathrm{yr}^{-1}$ in the top $0.05 \mathrm{~m}$ of the soil profile. Asymbiotic BNF rates decreased with $\mathrm{N} \& \mathrm{P}$ fertilization indicating that potentially positive effects of a higher $\mathrm{P}$ availability were counteracted by a higher mineral $\mathrm{N}$ availability. Intensive mowing stimulated asymbiotic BNF which was most likely caused by an increase in rhizodeposition. Furthermore, our calibration of the acetylene reduction assay with direct measurements of ${ }^{15} \mathrm{~N}_{2}$ fixation shows that in temperate grasslands the conversion factor can strongly deviate from the theoretical value of 3 and that this, together with laboratory incubations may lead to strong biases on estimates of asymbiotic BNF. We suggest that future studies should take these considerations into account.
\end{abstract}




\subsection{Introduction}

Nitrogen $(\mathrm{N})$ is an essential plant nutrient that limits primary productivity in most terrestrial ecosystems (Vitousek and Horwarth 1991). Although the atmosphere consists for about $80 \%$ of $\mathrm{N}_{2}$, this $\mathrm{N}$ cannot be used directly by plants. Before plants can use $\mathrm{N}$ it has to be 'fixed' in a reactive form (e.g. $\mathrm{NO}_{3}{ }^{-}$or $\mathrm{NH}_{4}{ }^{+}$) also called reactive nitrogen $\left(\mathrm{N}_{\mathrm{r}}\right)$. There are three major pathways through which $\mathrm{N}$ can enter the plant soil system: as $\mathrm{N}_{\mathrm{r}}$ through atmospheric $\mathrm{N}$ deposition, through fertilization and through biological $\mathrm{N}$ fixation (BNF). During BNF, atmospheric nitrogen is reduced to ammonia by microorganisms using the enzyme nitrogenase. In unfertilized terrestrial ecosystems, BNF is typically the most important pathway of $\mathrm{N}$ input (Reed et al. 2011).

In the past few decades, human activity has more than doubled $\mathrm{N}$ fixation especially through the chemical production of $\mathrm{N}$ fertilizers, the cultivation of legumes, and the production of N-oxides in internal combustion engines (Vitousek et al. 1997). While the anthropogenic increase of $\mathrm{N}$ fixation, fertilization, and $\mathrm{N}$ deposition has been reviewed extensively (e.g. Galloway et al. 2008) existing estimates of BNF are incomplete and spatially unresolved (Reed et al. 2011). Furthermore, it is unclear how BNF has changed from preindustrial rates to present day rates where BNF is potentially influenced by $\mathrm{N}$ deposition, fertilization, and other management practices.

In many ecosystems, symbiotic $\mathrm{N}$ fixation is the dominant pathway for BNF. However, asymbiotic BNF by free-living microorganisms may be an important pathway of $\mathrm{N}$ input in ecosystems where no or only few leguminous species are present. Existing data suggest that asymbiotic BNF may be dominant in temperate grassland ecosystems but the published rates are variable (Reed et al. 2011). A recent review reported an average asymbiotic BNF rate of $4.7 \mathrm{~kg} \mathrm{~N} \mathrm{ha}^{-1} \mathrm{yr}^{-1}$ for 13 temperate grasslands studies (Reed et al. 2011) while another review estimated a rate of $2.2 \mathrm{~kg} \mathrm{~N} \mathrm{ha}^{-1} \mathrm{yr}^{-1}$ for grasslands worldwide (Cleveland et al. 1999).

Most studies that measure BNF use the acetylene $\left(\mathrm{C}_{2} \mathrm{H}_{2}\right)$ reduction assay. This method is based on the discovery that nitrogenase, the enzyme responsible for $\mathrm{BNF}$, also reduces $\mathrm{C}_{2} \mathrm{H}_{2}$ to $\mathrm{C}_{2} \mathrm{H}_{4}$ (ethylene) (Hardy et al. 1968). Although BNF can nowadays be measured directly using ${ }^{15} \mathrm{~N}_{2}$ gas, the $\mathrm{C}_{2} \mathrm{H}_{2}$ reduction assay is still widely used because it is a low cost and sensitive method. If conducted well, the $\mathrm{C}_{2} \mathrm{H}_{2}$ reduction assay is calibrated against the ${ }^{15} \mathrm{~N}_{2}$ method. However, in many published BNF estimates a theoretical conversion factor has been used in the calculation of $\mathrm{N}$ fixation rates from $\mathrm{C}_{2} \mathrm{H}_{2}$ reduction rates, even though cross calibrations with the ${ }^{15} \mathrm{~N}_{2}$ fixation method have shown that conversion factors can 
deviate substantially from the stoichiometric value of 3 mole ethylene $\left(\mathrm{C}_{2} \mathrm{H}_{4}\right) /$ mole dinitrogen $\left(\mathrm{N}_{2}\right)$, (see e.g. Nohrstedt 1983 a). Furthermore, BNF estimates are often based on laboratory-incubations under altered temperature and/or moisture conditions, which can strongly affect rates of asymbiotic BNF. Finally, many studies used disturbed soil samples which will probably alter oxygen concentrations in the soil sample and influence the activity of the oxygen-sensitive nitrogenase enzyme. The only study that we found that estimated nonsymbiotic BNF in temperate grassland on undisturbed samples in the field and calibrated the conversion factor against the ${ }^{15} \mathrm{~N}_{2}$ method was conducted in the subalpine zone (Skujins et al. 1987), which makes it difficult to compare with lowland temperate grasslands.

Apart from uncertainties on the magnitude of asymbiotic BNF, information on ecological controls as well as the effect of agricultural management practices is also scarce (Cleveland et al. 1999, Vitousek et al. 2002). This lack of knowledge restricts our ability to predict future changes in BNF and with that in N cycling (Cleveland et al. 1999). European grasslands have been subject to agricultural intensification in the last decades (i.e. increased mowing frequency and fertilizer input), however no studies have been conducted on the influence of mowing combined with N\&P fertilization on asymbiotic BNF under fieldconditions.

Both $\mathrm{N}$ and phosphorus (P) have been reported to affect asymbiotic BNF (Reed et al. 2011). Several studies reported negative effects of $N$ fertilization on asymbiotic BNF (e.g. Vlassak et al. 1973) which can be attributed to higher mineral $\mathrm{N}$ concentrations in the soil inhibiting the enzyme nitrogenase (Yoch and Whiting 1986, Alexander 1977 cited by Patra et al. 2007). $\mathrm{P}$ is frequently discussed as the most important nutrient for asymbiotic BNF since it has high adenosine triphosphate (ATP) requirements. A study in an infertile grassland ecosystem reported e.g. a strong impact of the absolute $\mathrm{P}$ abundance on asymbiotic BNF (Reed et al. 2007). Given the contrasting effects of $\mathrm{N}$ and $\mathrm{P}$, it has also been suggested that $\mathrm{N}: \mathrm{P}$ ratios may be a better predictor for asymbiotic BNF than $\mathrm{N}$ or $\mathrm{P}$ concentrations alone (Eisele et al. 1989). In contrast, no effect of absolute P abundance on asymbiotic BNF nor of $\mathrm{N}: \mathrm{P}$ ratios have been reported by Hartley and Schlesinger (2002). They suggested that mineral $\mathrm{N}$ and available $\mathrm{C}$ rather than $\mathrm{P}$ or N:P ratios exert control over asymbiotic BNF.

Apart from fertilization, mowing may also affect asymbiotic BNF in grasslands since plant defoliation increases rhizodeposition, thus providing easily available carbon for soil microorganisms (e.g. Holland et al. 1996). This C-input is important because asymbiotic BNF is a heterotrophic energy-intensive process which depends on available $\mathrm{C}$ as its energy source. In laboratory experiments, increases in asymbiotic BNF have been observed following the 
addition of artificial root exudates to soil samples (Bürgmann et al. 2005). If mowing stimulates asymbiotic BNF through increasing rhizodeposition, we would expect that this is reflected by an increase in soil microbial biomass which respires high amounts of $\mathrm{C}$ released into the rhizosphere (Guitian and Bardgett 2000).

Here, we test the influence of combined N \& P fertilization and mowing frequency on asymbiotic BNF. We tested the following hypotheses: 1) fertilization with $\mathrm{N}$ and $\mathrm{P}$ in a commonly applied mass ratio (180 kg N and $30 \mathrm{~kg} \mathrm{P} \mathrm{ha}^{-1} \mathrm{yr}^{-1}$ ) will decrease asymbiotic BNF; 2) intensive mowing will increase asymbiotic BNF due to increasing root exudation which will be reflected in a larger soil microbial biomass. We conducted year-round field and laboratory incubations of asymbiotic BNF using the $\mathrm{C}_{2} \mathrm{H}_{2}$ reduction assay in a temperate managed grassland site under different fertilization- and mowing-treatments. Additionally, soil microbial biomass, soil mineral $\mathrm{N}$ and resin exchangeable $\mathrm{P}$ were determined. Our results show that asymbiotic BNF can provide a significant input of $\mathrm{N}$ into unfertilized temperate grassland ecosystems. Furthermore, our results indicate that estimates of BNF rates using theoretical conversion factors and/or lab-incubated samples maybe substantially biased.

\subsection{Material and Methods}

\subsubsection{Site Description}

Our study (which is part of the grassland management project "GRASSMAN") was conducted at a moderately species rich permanent grassland site in the Solling uplands, Lower Saxony, Germany (514' $53 " \mathrm{~N}, 9^{\circ} 32^{\prime} 42$ "E, $490 \mathrm{~m}$ above sea level). This site (which presently belongs to the experimental farm Relliehausen) has been used for grazing and hay production for at least 100 years (Geological Map of Prussia 1910, based on the topographic inventory of 1896; topographic maps of Sievershausen and Neuhaus/Solling 1924, 1956 and 1974). During the last 50 years, the site was used for cattle grazing, received moderate fertilizer applications (80 $\mathrm{kg} \mathrm{N} \mathrm{ha}^{-1} \mathrm{yr}^{-1}$ ) and occasional liming and was over-seeded with high value forage species (farm records of Relliehausen since 1966). No fertilizer was applied during the last two years before the experiment was conducted. Prior to the experiment the plant community was classified as a montane, semi-moist Lolio-cynosuretum. The dominating soil type - a haplic Cambisol (IUSS Working Group WRB 2006) with a loamy silt texture - has developed on loess sediments overlaying sandstones of the Middle Buntsandstein formation. Mean annual temperature and precipitation are $6.9^{\circ} \mathrm{C}$ and $1028 \mathrm{~mm}$ (Deutscher Wetterdienst, 1961 - 1990, station Holzminden-Silberborn, 440 m above sea level). Detailed information on soil physical and chemical parameters are reported in Keuter et al. (2012). 


\subsubsection{Experimental set-up}

Our study is conducted using a two-factorial design including two fertilization treatments and two mowing frequencies. Prior to the experiment, the complete study site was mown and fertilized plots received $50 \mathrm{~kg} \mathrm{~N} \mathrm{ha}^{-1}$. In spring 2009, two mowing frequencies (one and three times per year) and two fertilization treatments were established (180 - $30-100 \mathrm{~kg}$ NPK ha-1 $\mathrm{yr}^{-1}$ and no fertilization). In 2009, Thomaskali ${ }^{\circledR}$ (K+S KALI GmbH, Kassel, Germany) containing 6-9 mg kg-1 Molybdenum (Mo) was used for $\mathrm{P}$ and $\mathrm{K}$ fertilization. After that, "PK+ Dünger" (ICL Fertilizers Deutschland GmbH, Ludwigshafen, Germany) containing 12 mg kg-1 Mo was applied. Calcium ammonium nitrate N27 fertilizer (ICL Fertilizers Deutschland $\mathrm{GmbH}$, Ludwigshafen, Germany) was used for $\mathrm{N}$ fertilization throughout the whole experimental period. Fertilization was split into two equal applications per year and was conducted in April and May/June (2009 - 2012). Mowing was conducted in May, July and September (2009 - 2012) for the plots cut three times per year and in July (2009 - 2012) for the plots cut once per year. The combination of the two factors resulted in four different treatments. Each treatment was replicated 18 times. The 72 treatment plots (15 m x $15 \mathrm{~m}$ ) were arranged in a Latin rectangle design. For the present study 48 of these plots (14 replicates per treatment) were sampled.

In June 2008, three different sward compositions differing in the proportions of monocotyledons and dicotyledons and in species richness were established by applying selective herbicides (see Keuter et al. 2012 for detailed information). This resulted in significant changes in sward composition in 2009 and 2010 (Keuter et al. 2012). However, in 2011 the vegetation survey (From et al., unpublished data) did not reveal significant differences among treatments in species richness and only a marginal difference in monocot abundance between control and dicot-enhanced treatments (control sward consisted of 72\% monocots, $27 \%$ dicots and 1\% legumes; monocot-enhanced sward consisted of 75\% monocots, 25\% dicots and 0\% legumes; dicot-enhanced sward consisted of 68\% monocots, $30 \%$ dicots and $2 \%$ legumes). In the present study, we included sward composition as a fixed effect in all statistical models testing treatment differences to account for the variance potentially still caused by this factor. However, sward composition did not affect any of the presented parameters.

\subsubsection{Biological nitrogen fixation}

BNF was determined using the $\mathrm{C}_{2} \mathrm{H}_{2}$ reduction assay (Hardy et al. 1968). At each sampling date, one intact soil core $\left(100 \mathrm{~cm}^{3}\right)$ per plot was taken at $0.00-0.05 \mathrm{~m}$ depth (four replicates 
per treatment combination). Sampling points were chosen at random. If leguminous species were found within an area of $0.5 \mathrm{~m}$ around the sampling point, another sampling point was chosen. Intact, field moist soil cores were incubated in vacuum-proof glass jars $(1100 \mathrm{ml}$ volume). Parafilm (Parafilm $\mathrm{M}{ }^{\circledR}$ Laboratory Film) was wrapped around the top before jars were closed with metal lids equipped with rubber septa. $10 \%$ of the headspace air was exchanged against $\mathrm{C}_{2} \mathrm{H}_{2}$ (cylinder $\mathrm{C}_{2} \mathrm{H}_{2}$ with 99\% purity, Westfalen AG, Münster Westf., Germany) using a gas-proof syringe. $\mathrm{C}_{2} \mathrm{H}_{2}$ was purified by passing it through $98 \%$ sulfuric acid and 5M sodium hydroxide solution as described by Hyman and Arp (1986). Field incubation for $24 \mathrm{~h}$ was done under ambient temperature and soil moisture conditions. Incubation jars were kept on the ground and protected against direct sunlight. Gas samples were taken one, three and 24 hours after $\mathrm{C}_{2} \mathrm{H}_{2}$ injection using a gas-proof syringe and transferred into pre-evacuated vials (Labco Exetainer ${ }^{\circledR}$ ). Gas samples were analyzed for $\mathrm{C}_{2} \mathrm{H}_{4}$ concentrations using a gas chromatograph (Shimadzu GC 14-B) equipped with a flame ion detector (FID) and Heyesep T columns. Column oven and FID temperatures were $80^{\circ} \mathrm{C}$ and $290^{\circ} \mathrm{C}$, respectively. Nitrogen was used as a carrier gas. Calibration was conducted using four different $\mathrm{C}_{2} \mathrm{H}_{4}$ concentrations which were made by mixing $\mathrm{C}_{2} \mathrm{H}_{4}(99.5 \%$ purity, Westfalen AG, Münster Westf., Germany) with ambient air. Field moist soil cores were weighed and mixed after incubation. Additionally, samples that showed $\mathrm{C}_{2} \mathrm{H}_{4}$ production were checked for the presence of root nodules, which were never observed. Sample dry weights were calculated from field moist weights and the gravimetric moisture (determined by oven-drying at $105^{\circ} \mathrm{C}$ for $24 \mathrm{~h}$ ). $\mathrm{C}_{2} \mathrm{H}_{4}$ production rates were calculated from the slope of the regression line of the $\mathrm{C}_{2} \mathrm{H}_{4}$ concentrations over time. Dry mass based rates were converted to area based rates using the average measured bulk density of $0.79 \mathrm{~g} \mathrm{~cm}^{-3}$. Average rates in $\mathrm{mg} \mathrm{N} \mathrm{m}^{-2} \mathrm{~d}^{-1}$ per treatment were extrapolated to $\mathrm{kg} \mathrm{N} \mathrm{ha}^{-1} \mathrm{yr}^{-1}$ using the trapezoid rule on time intervals. We assumed that no asymbiotic BNF occurred in the winter months between Nov $10^{\text {th }} 2011$ and Apr $11^{\text {th }} 2012$ when no measurements were conducted and low temperatures were likely to inhibit asymbiotic BNF.

A cross calibration with direct ${ }^{15} \mathrm{~N}_{2}$ fixation measurements was conducted in August 2011 to determine the conversion factor between $\mathrm{C}_{2} \mathrm{H}_{4}$ production and $\mathrm{N}_{2}$ fixation. The cross calibration was performed at six plots where considerable $\mathrm{C}_{2} \mathrm{H}_{4}$ production had been observed. Six parallel soil cores per plot covered with the same plant species were taken close to one another. Two of these cores were used for the $\mathrm{C}_{2} \mathrm{H}_{2}$ reduction method as described above. One core was incubated in a ${ }^{15} \mathrm{~N}$ enriched atmosphere for $10 \mathrm{~d}$. About $100 \mathrm{ml}$ of the headspace were exchanged against ${ }^{15} \mathrm{~N}_{2}$ isotope gas $\left({ }^{15} \mathrm{~N}\right.$ enrichment of $98 \%$, Cambridge, 
Isotope Laboratories, Inc.) to achieve a concentration of approx. 10 atom $\%{ }^{15} \mathrm{~N}$. Another core was incubated as reference sample in ambient air for $10 \mathrm{~d}$. The same jars as described above were used for field incubation. Incubation jars were stored in approx. $20 \mathrm{~cm}$ deep holes in the ground covered with white, translucent plastic plates. Oxygen concentrations in the headspace were measured at the end of each incubation period using a Digital Oxymeter equipped with a syringe needle (Greisinger GMH 3691). Gas samples were taken at the beginning and at the end of each incubation period and analyzed for ${ }^{15} \mathrm{~N}$ concentration with an isotope ratio mass spectrometer (IRMS). Soil samples were air-dried at $40^{\circ} \mathrm{C}$, sieved to $2 \mathrm{~mm}$, ground in a ballmill and analyzed for ${ }^{15} \mathrm{~N}$ concentrations using IRMS. $\mathrm{N}$ fixation was calculated for each sample according to:

$N_{\text {fix }}=\left({ }^{15} N_{N e^{-}}{ }^{15} N_{N s}\right) *\left(N_{c}\right) *\left({ }^{15} N_{N 2}-{ }^{15} N_{N S}\right)^{-1} *(t){ }^{-1} *\left(m_{\text {mole }}\right)^{-1}$

where $N_{\text {fix }}=\mathrm{N}_{2}$ fixation rate (mole $\mathrm{N}_{2}$ kg dry mass ${ }^{-1} \mathrm{~d}^{-1}$ )

${ }^{15} N_{\text {Inc }}={ }^{15} \mathrm{~N}$ content (atom \%) of the incubated sample

${ }^{15} N_{N s}={ }^{15} \mathrm{~N}$ content (atom \%) of the reference sample

$N_{c}=$ total $\mathrm{N}$ content of the soil sample (mg $\mathrm{N} \mathrm{kg}$ dry mass ${ }^{-1}$ )

${ }^{15} N_{N 2}=$ average ${ }^{15} \mathrm{~N}$ content of the $\mathrm{N}_{2}$ fixed before and after incubation (atom \%)

$t=$ the incubation time (d)

$m_{\text {mole }}=$ molar mass of $\mathrm{N}_{2}\left(\mathrm{mg} \mathrm{mol}^{-1}\right)$

The conversion factor between $\mathrm{C}_{2} \mathrm{H}_{4}$ production and $\mathrm{N}_{2}$ fixation was calculated for each of the six plots according to:

$\mathrm{F}=(E t h) /\left(N_{f i x}\right)$

where $\mathrm{F}$ is the conversion factor, $\mathrm{N}_{\text {fix }}=\mathrm{N}_{2}$ fixation rate (mole $\mathrm{N}_{2} \mathrm{~kg}$ dry mass ${ }^{-1} \mathrm{~d}^{-1}$ ), Eth $=$ average of $\mathrm{C}_{2} \mathrm{H}_{4}$ production rate of the two parallel $\mathrm{C}_{2} \mathrm{H}_{2}$-incubated samples (mole $\mathrm{C}_{2} \mathrm{H}_{4} \mathrm{~kg}$ dry mass ${ }^{-1} \mathrm{~d}^{-1}$ ). The average of the six calculated conversion factors was used for the calculation of $\mathrm{N}$ fixation rates from $\mathrm{C}_{2} \mathrm{H}_{4}$ production rates.

\subsubsection{Test for endogenous $\mathrm{C}_{2} \mathrm{H}_{4}$ production and $\mathrm{C}_{2} \mathrm{H}_{4}$ consumption}

To test for endogenous production of $\mathrm{C}_{2} \mathrm{H}_{4}$, one intact soil core per treatment was incubated in an atmosphere of approx. $0.05 \% \mathrm{C}_{2} \mathrm{H}_{2}$ for $24 \mathrm{~h}$. Incubating substrates in low concentrations of $\mathrm{C}_{2} \mathrm{H}_{2}$ inhibits the oxidation of produced $\mathrm{C}_{2} \mathrm{H}_{4}$ without inducing reduction of $\mathrm{C}_{2} \mathrm{H}_{2}$ (Nohrstedt 1983 b). Endogenous production of $\mathrm{C}_{2} \mathrm{H}_{4}$ at our site was so low that it did not 
exceed the detection limit of the GC when measured against background levels of $\mathrm{C}_{2} \mathrm{H}_{4}$ in samples containing $10 \% \mathrm{C}_{2} \mathrm{H}_{2}$. In consequence, we did not account for endogenous $\mathrm{C}_{2} \mathrm{H}_{4}$ production when determining BNF.

To determine microbial degradation of $\mathrm{C}_{2} \mathrm{H}_{4}$, one soil core per treatment was incubated in an atmosphere of approx. $0.001 \% \mathrm{C}_{2} \mathrm{H}_{4}$ for $24 \mathrm{~h}$ and $\mathrm{C}_{2} \mathrm{H}_{4}$ concentrations were monitored. No significant decrease in the concentrations of $\mathrm{C}_{2} \mathrm{H}_{4}$ was detected.

\subsubsection{Potential asymbiotic BNF}

For the determination of potential $\mathrm{N}$ fixation, intact soil cores were irrigated to field capacity. Soil sampling rings were closed with a filter paper (595, Schleicher \& Schuell, Germany, ø 90 $\mathrm{mm}$ ) at the bottom and placed on a water-saturated sand layer to allow for capillary rise (Synthetic sand 08.01.09. Eijkelkamp, the Netherlands, particle size $\sim 73 \mu \mathrm{m}$ ) for $12 \mathrm{~h}$ at approx. $20^{\circ} \mathrm{C}$. Subsequently, the $\mathrm{C}_{2} \mathrm{H}_{2}$ reduction assay was conducted in a climate chamber at a temperature of $20^{\circ} \mathrm{C}$ (12 h lightened and $12 \mathrm{~h}$ in the dark).

\subsubsection{Microbial biomass $\mathrm{C}$ and $\mathrm{N}$ and soil mineral $\mathrm{N}$}

Soil microbial $\mathrm{C}$ and $\mathrm{N}$ contents were determined with the fumigation-extraction method (Brookes et al. 1985) in June 2012. Five samples per plot were taken with an auger from the Ah horizon (0.00-0.05 m depth), pooled together and mixed well. One subsample per plot ( $\sim 15 \mathrm{~g}$ ) was immediately extracted in the field with $75 \mathrm{ml} 0.5 \mathrm{M} \mathrm{K}_{2} \mathrm{SO}_{4}$. Another subsample was placed in a desiccator containing a beaker with chloroform $\left(\mathrm{CHCl}_{3}\right)$. In order to distribute the $\mathrm{CHCl}_{3}$ vapor, the desiccator was evacuated until the $\mathrm{CHCl}_{3}$ started to boil. The samples were fumigated for $5 \mathrm{~d}$. Subsequently the desiccator was flushed with air and evacuated several times to remove $\mathrm{CHCl}_{3}$ from the soil samples. After that, samples were extracted with $0.5 \mathrm{M} \mathrm{K}_{2} \mathrm{SO}_{4}$. All soil extracts were shaken for $1 \mathrm{~h}$, filtered through Whatman $595 \frac{1}{2}$ folded filters, and kept frozen until analysis. Total extractable $\mathrm{N}(\mathrm{TN})$, Ammonium $\left(\mathrm{NH}_{4}{ }^{+}\right)$and Nitrate $\left(\mathrm{NO}_{3}{ }^{-}\right)$concentrations were determined using continuous flow injection colorimetry (Skalar, Cenco Instruments, Breda, The Netherlands). UV-persulfate oxidation and hydrazine sulfate reduction (Skalar Method 473-000) was used for the determination of TN, Berthelot reaction method (Skalar Method 155-000) for the determination of $\mathrm{NH}_{4}{ }^{+}$and coppercadmium reduction method (Method 461-000) for the determination of $\mathrm{NO}_{3}{ }^{-}$. Extractable organic C was analyzed with a Dohrmann DC-80 Carbon Analyzer equipped with an infrared detector (Rosemount Analytical Division, CA, USA) using ultraviolet (UV)-enhanced persulfate oxidation. Microbial biomass $\mathrm{C}$ and $\mathrm{N}$ were calculated as the difference in 
extractable $\mathrm{N}$ and $\mathrm{C}$ between fumigated and unfumigated samples divided by a conversion factor of 0.68 for $\mathrm{N}$ and 0.45 for C (Brookes et al. 1985, Joergensen 1996).

\subsubsection{Resin-exchangeable $\mathbf{P}$}

Resin-exchangeable $\mathrm{P}\left(\mathrm{P}_{\text {resin }}\right)$ was determined in June 2010 with exchange resins according to the method described by Tiessen et al. (1983). Composite soil samples were taken as described above. Samples were air-dried at $40^{\circ} \mathrm{C}$ for seven days and sieved to $2 \mathrm{~mm}$. Soil samples $(0.5 \mathrm{~g})$ were shaken in $30 \mathrm{ml}$ distilled water for $12 \mathrm{~h}$ together with $1 \mathrm{~g}$ of pelletshaped anion exchange resin (DOWEX 41081 analytical grade, Serva Electrophoresis GmbH, Heidelberg, Germany) kept in a tea-bag. Subsequently, tea-bags containing the exchange resin were cleaned with distilled water and shaken in $20 \mathrm{ml} 0.5 \mathrm{~m} \mathrm{HCl}$ for $12 \mathrm{~h}$. After centrifugation of the samples, the supernatant was frozen until analysis for P using ICP-AES.

\subsubsection{Statistical Analysis}

The impact of the treatment factors on BNF and potential BNF was tested with linear mixed effects models. Sampling date and plot were included as random factors to account for pseudoreplication. Soil moisture was included as a covariable and row and column of the Latin rectangle design were included as fixed effects. Data were tested for autocorrelation. In case of heteroscedastic residuals, data were log-transformed and/or a variance function was included if this improved Akaikes likelihood criterion (AIC). Row, column, and nonsignificant interaction terms were deleted stepwise from the statistical model if this did not significantly increase the error variance. The correlations between treatment means of BNF and soil moisture contents per sampling date were tested with Spearman's rank correlation. The impact of treatment effects on microbial $\mathrm{C}$ and $\mathrm{N}$ as well as concentrations of mineral $\mathrm{N}$ and available P were tested with analysis of variance. Row and column of the Latin rectangle were included as fixed effects. Residuals were checked for normality and homoscedasticity and data were log-transformed in case of non-normally distributed and/or heteroscedastic residuals. Statistical models were simplified stepwise as described above. All effects were regarded as significant at $P \leq 0.05$ unless stated otherwise. 


\subsection{Results}

\subsubsection{Microbial $\mathrm{C}$ and $\mathrm{N}$ contents and $\mathrm{C}: \mathrm{N}$ ratios}

Soil microbial biomass C ranged from 360 to $1260 \mathrm{mg} \mathrm{C} \mathrm{kg} \mathrm{dry} \mathrm{mass}{ }^{-1}$ and increased marginally with increasing mowing frequency (Fig. 6a, $P=0.075$ ) but was not affected by fertilization (Fig. 6b). Soil microbial biomass $\mathrm{N}$ ranged from 85 to $130 \mathrm{mg} \mathrm{N} \mathrm{kg} \mathrm{dry} \mathrm{mass}{ }^{-1}$ and increased with increasing mowing frequency $(P=0.020)$. Fertilization again had no effect. Microbial biomass C:N ratios varied from 4 to 12 and were not influenced by any of the treatment factors.

\subsubsection{Soil mineral $\mathbf{N}$ and resin-exchangeable $P$}

Concentrations of total mineral $\mathrm{N}\left(\mathrm{NH}_{4}{ }^{+}+\mathrm{NO}_{3}{ }^{-}\right)$varied between 0.29 and 4.64 mmole $\mathrm{N} \mathrm{kg}$ dry mass ${ }^{-1}$. $\mathrm{NO}_{3}{ }^{-}$concentrations were generally lower than those of $\mathrm{NH}_{4}{ }^{+}$and did not exceed 0.04 mmole $\mathrm{N} \mathrm{kg}$ dry mass ${ }^{-1}$ on the unfertilized plots. Total mineral $\mathrm{N}$ concentrations were were higher on fertilized plots $(P<0.001$, Fig. 7 b) while mowing frequency (Fig. 7 a) had no effect.

Concentrations of $\mathrm{P}_{\text {resin }}$ ranged from 2.13 to 8.36 mmole $\mathrm{P}$ kg dry mass ${ }^{-1}$ but on the unfertilized plots they did not exceed 5 mmole P kg dry mass ${ }^{-1}$. Fertilization was the only treatment affecting $\mathrm{P}_{\text {resin }}(P=0.016)$ with higher concentrations on the fertilized plots (Fig. 7 b). Total mineral $\mathrm{N}: \mathrm{P}_{\text {resin }}$ ratios were enhanced by fertilization $(P<0.001$, Fig. 7 b) and increased with increasing mowing frequency $(P=0.011$, Fig. 7 a).

\subsubsection{Conversion factor between $\mathrm{N}$ fixation and $\mathrm{C}_{2} \mathrm{H}_{2}$ reduction}

The average conversion factor between $\mathrm{C}_{2} \mathrm{H}_{4}$ produced and $\mathrm{N}_{2}$ fixed (mole $\mathrm{C}_{2} \mathrm{H}_{4} \mathrm{~kg}^{-1} \mathrm{~d}^{-1}$ / mole $\mathrm{N}_{2} \mathrm{~kg}^{-1} \mathrm{~d}^{-1}$ ) was $0.61( \pm 0.29 \mathrm{SE})$. One ${ }^{15} \mathrm{~N}$ incubated sample showed an oxygen concentration $<10 \%$ in the headspace after incubation and was excluded from further calculations. Oxygen concentrations in the headspace were not significantly correlated with ${ }^{15} \mathrm{~N}$ based $\mathrm{N}$ fixation rates (Spearman's correlation coefficient $=0.6 ; P=0.242$, data not shown). 

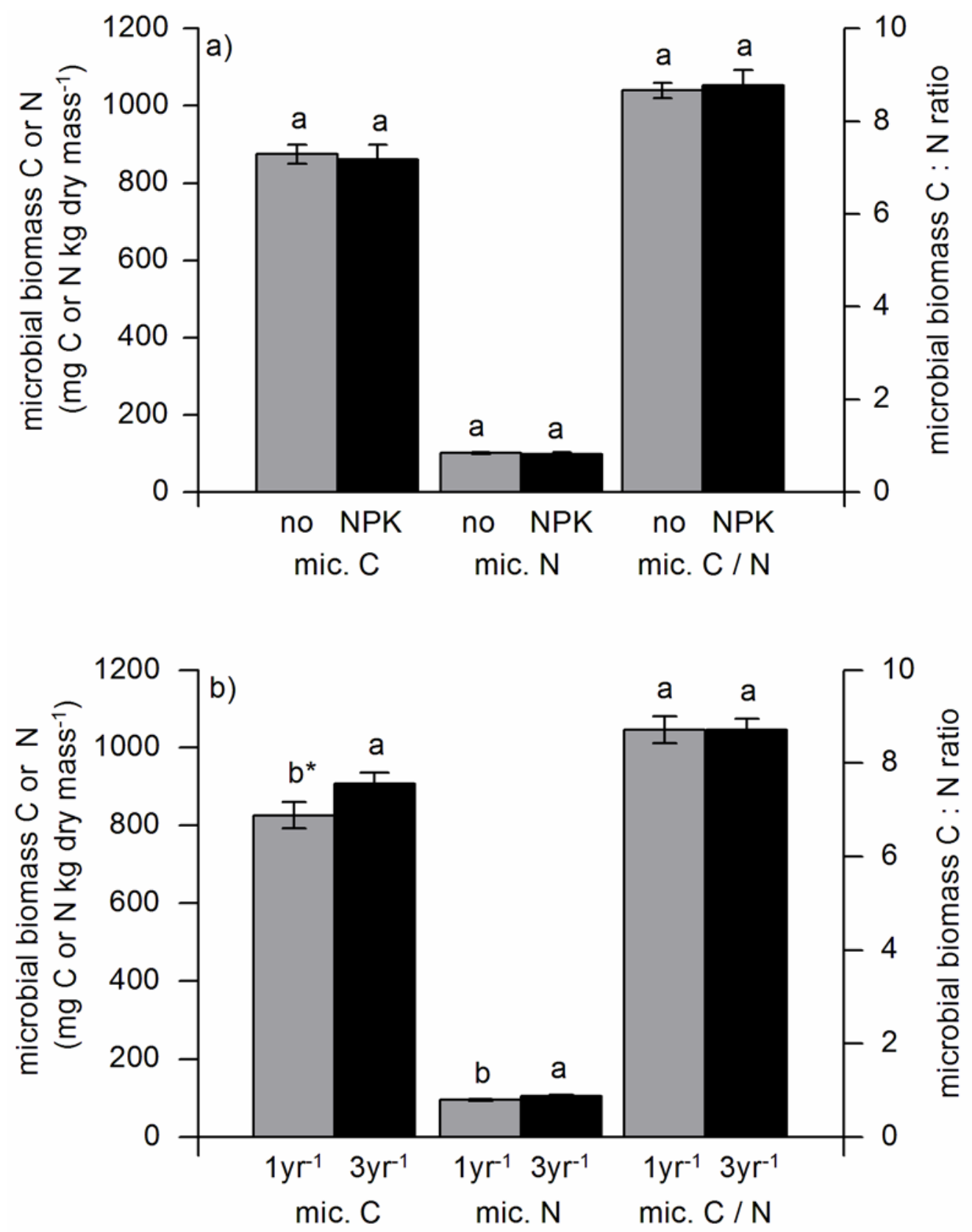

Figure 6: Soil microbial biomass carbon and nitrogen and microbial carbon : nitrogen ratios ( \pm standard errors) of a grassland (0.00-0.05 m depth) under a) different fertilization treatments (no = unfertilized, NPK = fertilized) and b) different mowing frequencies $\left(1 \mathrm{yr}^{-1}=\right.$ one mowing per year, $3 \mathrm{yr}^{-1}=$ three mowings per year $)$ in the Solling uplands, Germany. Columns with different letter indicate significant differences among treatments (ANOVA at $P \leqq 0.05, *=$ marginally significant, $\mathrm{P} \leqq 0.1$ ). 

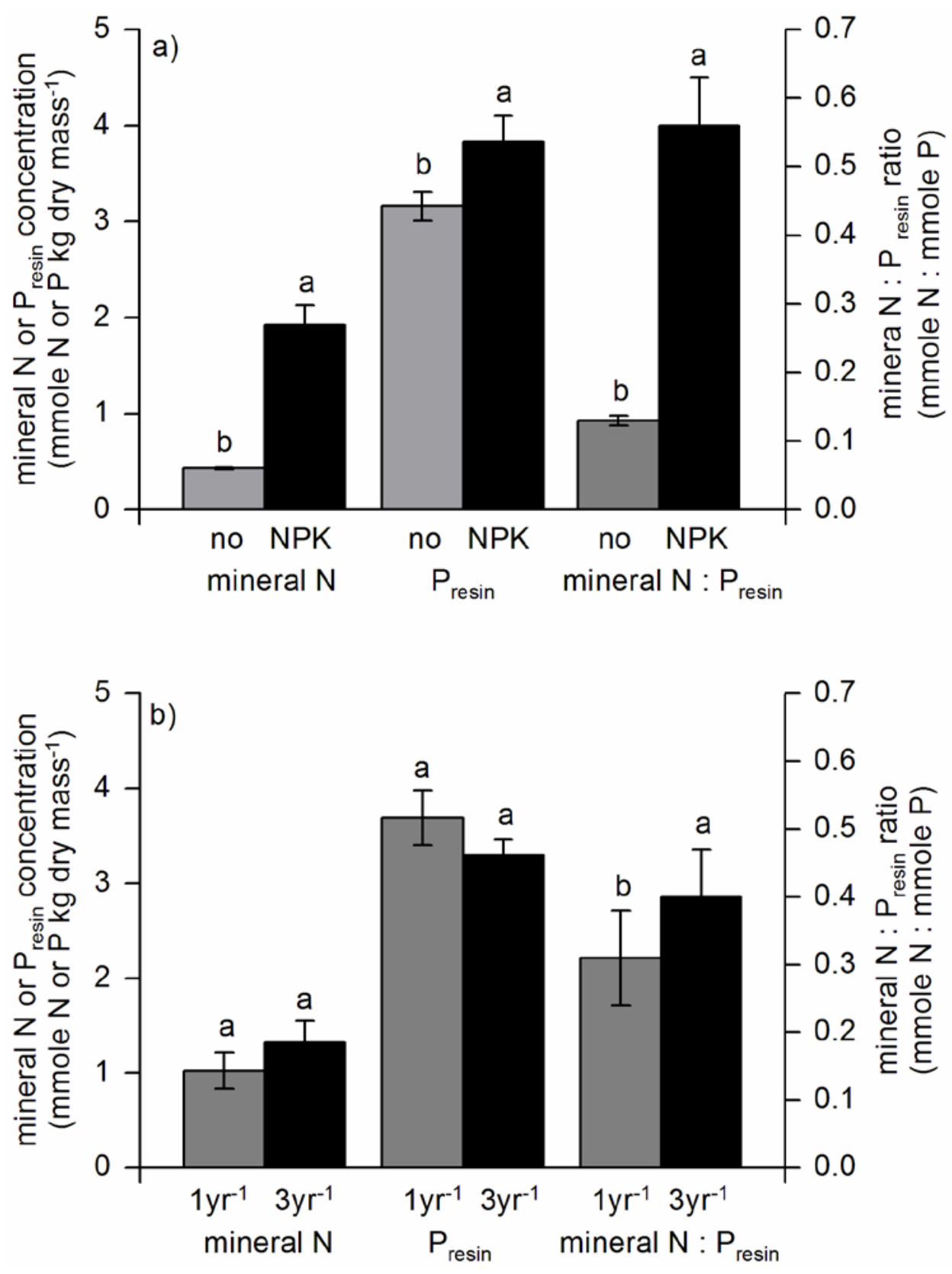

Figure 7: Total soil mineral $\mathrm{N}\left(\mathrm{NH}_{4}{ }^{+}-\mathrm{N}+\mathrm{NO}_{3}{ }^{-}-\mathrm{N}\right)$ and resin exchangeable $\mathrm{P}\left(\mathrm{P}_{\text {resin }}\right)$ concentrations $( \pm$ standard errors) of a grassland (0.00-0.05 m depth) under a) different fertilization treatments (no = unfertilized, NPK = fertilized) and b) different mowing frequencies $\left(1 \mathrm{yr}^{-1}=\right.$ one mowing per year, $3 \mathrm{yr}^{-1}=$ three mowings per year in the Solling uplands, Germany. Columns with different letter indicate significant differences among treatments (ANOVA at $P \leqq 0.05$ ). 


\subsubsection{Asymbiotic BNF and potential asymbiotic BNF}

Rates of asymbiotic BNF were characterized by a high spatial variability (Fig. 8). Within treatment combinations and at the same sampling date, rates varied from no detectable $\mathrm{N}$ fixing activity up to $10 \mathrm{mg} \mathrm{N} \mathrm{m}^{-2} \mathrm{~d}^{-1}$ (in extreme cases up to $30-42 \mathrm{mg} \mathrm{N} \mathrm{m}^{-2} \mathrm{~d}^{-1}$ ). Across all treatments, average rates were relatively high between June and September 2011 while only low activities could be detected in November 2011 and in April and May 2012. Extrapolated to one hectare, annual inputs of N provided by asymbiotic BNF ranged between 1.5 and 4.9 $\mathrm{kg} \mathrm{N}$ in the upper $5 \mathrm{~cm}$ of the soil profile, depending on the treatment combination (Appendix 2). Both fertilization $(P=0.017)$ and mowing frequency $(P=0.046)$ affected asymbiotic BNF with higher rates on the unfertilized plots and the plots cut three times per year.

With a few exceptions, fertilization decreased asymbiotic BNF throughout the whole measurement period. We did not detect a short-term effect of fertilization on asymbiotic BNF following fertilization applications. Asymbiotic BNF increased with soil moisture $(P<0.001)$. In contrast, treatment means per sampling date of BNF and soil moisture contents were not significantly correlated (Spearman's correlation coefficient: 0.067, $P=0.880$ ).

Asymbiotic BNF showed a strong rapid reaction to mowing: In May 2011, when mowing was conducted on the plots cut three times per year, we measured relatively high rates of BNF. Furthermore, both plots cut once and three times per year showed an increase in asymbiotic BNF after the second mowing in July 2011. Also in September 2011, when mowing was only conducted at plots cut three times per year, the overall increase in asymbiotic BNF was pronounced on these plots.

Rates of potential asymbiotic BNF (Fig. 9) measured in October 2011 were considerably higher than rates measured under field-conditions. Compared to the overall mean of BNF rates measured in the field, lab-incubations resulted in an increase by a factor of seven. In contrast to field-incubations potential asymbiotic BNF was not affected by mowing frequency (Fig. 9a) and fertilization (Fig. 9b) ( $P=0.510$ and $P=0.169$, respectively). 

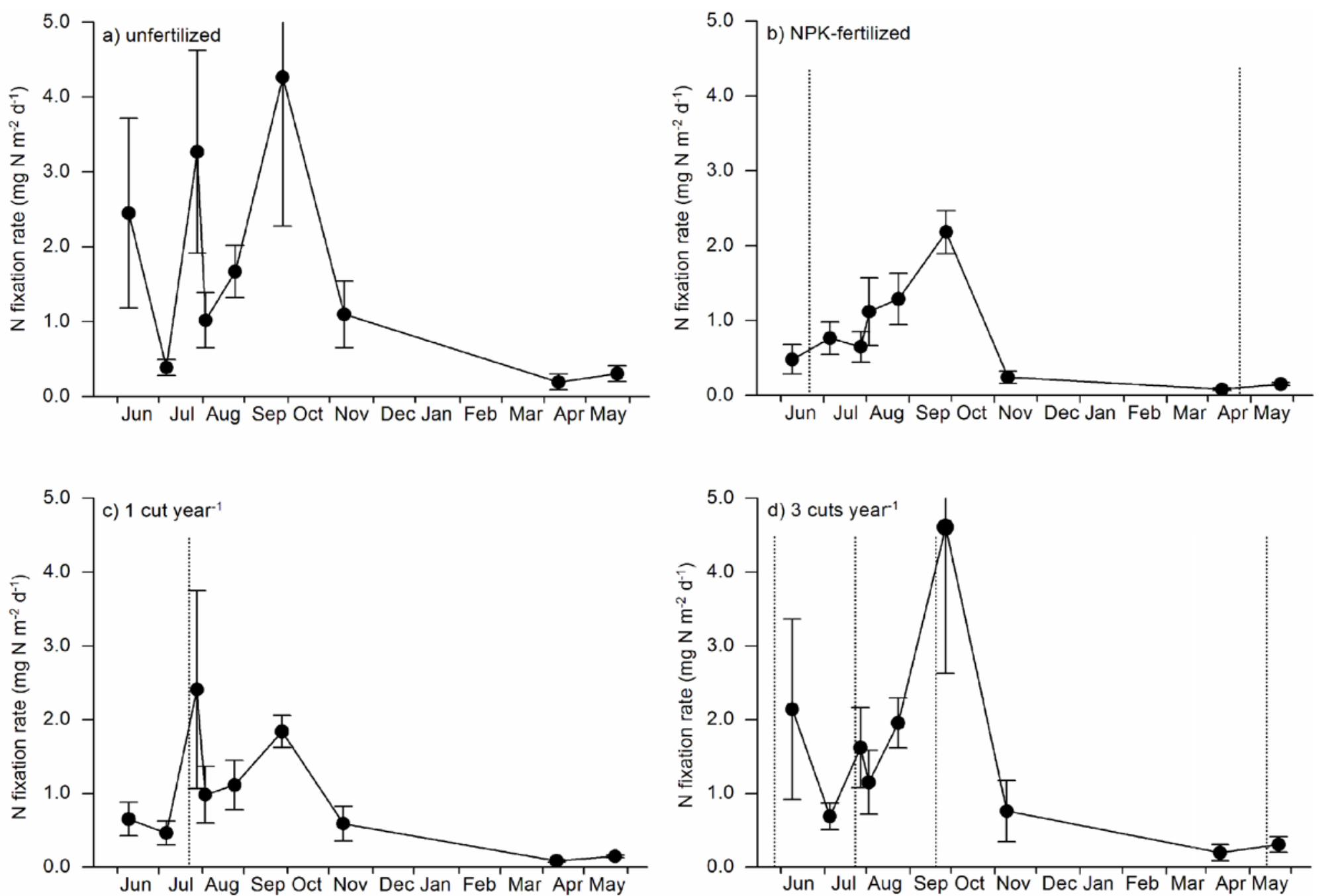

Figure 8: Rates of asymbiotic biological nitrogen fixation ( \pm standard errors) of a grassland under and different fertilization treatments and mowing frequencies (a) unfertilized, b) NPK-fertilized, c) one cut per year, d) three cuts per year) in the Solling uplands, Germany. Average measured soil bulk density of 0.79 g cm ${ }^{-3}$ and $0.00-0.05$ m depth was used to convert rates from dry mass basis to area basis. Vertical, dotted lines symbolize fertilization and mowing events, respectively. Both fertilization $(P=0.017)$ and mowing frequency $(P=0.046)$ significantly affected rates of asymbiotic BNF (linear mixed effects model $(\mathrm{LME})$ at $\mathrm{P} \leqq 0.05)$. 


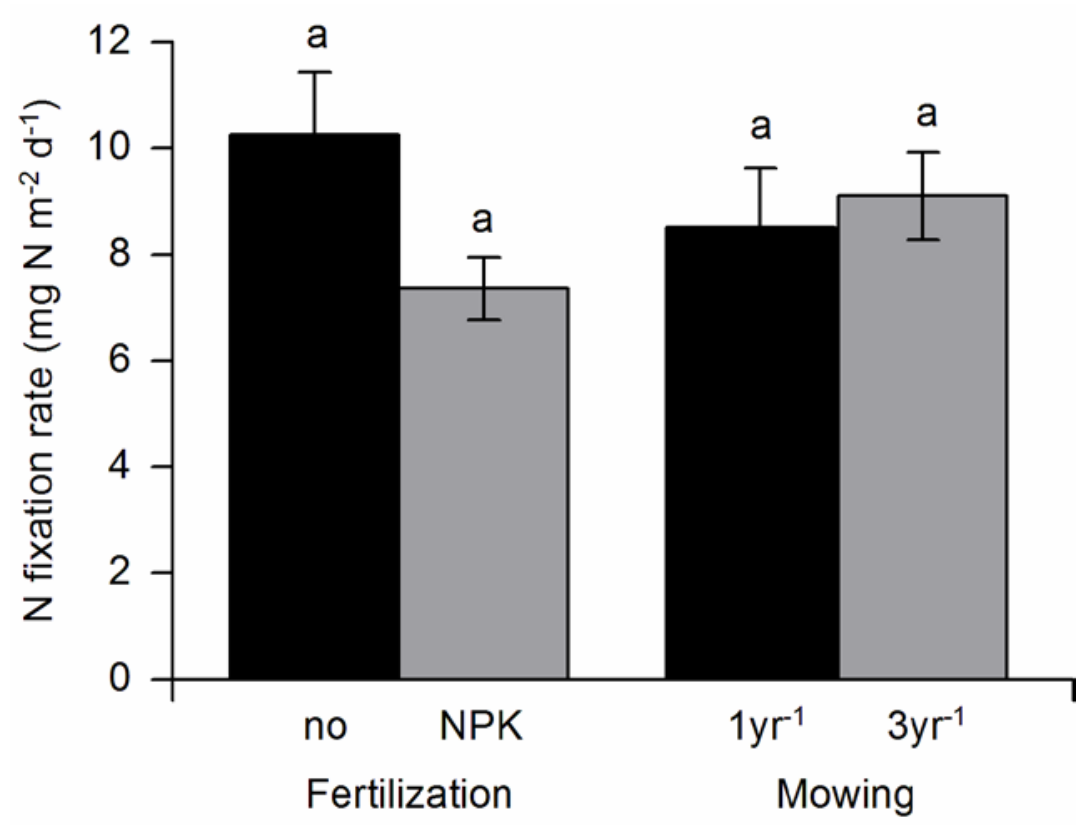

Figure 9: Potential asymbiotic biological nitrogen fixation ( \pm standard errors) of a grassland under different mowing frequencies $\left(1 \mathrm{yr}^{-1}=\right.$ one mowing per year, $3 \mathrm{yr}^{-1}=$ three mowings per year $)$ and fertilization treatments (no = unfertilized, NPK = fertilized) in the Solling uplands, Germany. Average measured soil bulk density of $0.79 \mathrm{~g} \mathrm{~cm}^{-3}$ and $0.00-0.05 \mathrm{~m}$ depth was used to convert rates from dry mass basis rates to area basis. Columns with different letter indicate significant differences among treatments (ANOVA at $P \leqq 0.05$ ).

\subsection{Discussion}

\subsubsection{Conversion factors and asymbiotic BNF rates}

The conversion factor determined in our study (0.61) was clearly below the theoretical conversion factor of 3 which is conventionally used in calculating $\mathrm{N}_{2}$ fixed from $\mathrm{C}_{2} \mathrm{H}_{4}$ produced. Conversion factors lower than three have been reported for temperate grasslands by other authors (Zechmeister-Boltenstern and Kinzel 1990: conversion factor of 2.1; Vlassak et al. 1973: conversion factor of 2.6) and can result from a disturbed enzyme production caused by $\mathrm{C}_{2} \mathrm{H}_{2}$, toxic effects of $\mathrm{C}_{2} \mathrm{H}_{2}$ on $\mathrm{N}$ fixing organisms, or absorbance of $\mathrm{C}_{2} \mathrm{H}_{2}$ to soil colloids (Nohrstedt 1983 a). Our conversion factors are clearly below these values, however for other ecosystems much lower conversion factors have been reported. For instance, Belnap (2001) reported a factor of 0.31 for soil crusts while Liengen et al. (1999) determined factors of between 0.11 and 0.48 for sheets of Nostoc commune and between 0.022 and 0.073 for cyanobacterial crusts in arctic habitats. Given these low published values, we think that our conversion factors are plausible, even though they are to lowest published for temperate grasslands. Methodical biases leading to low conversion factors could arise from the relatively long incubation time (10 d) under ${ }^{15} \mathrm{~N}$ compared to one-day incubation under $\mathrm{C}_{2} \mathrm{H}_{2}$. A longer 
incubation time might lead to low oxygen concentrations in the incubation jars due to microbial consumption during organic matter decomposition. This may increase the activity of anaerobic $\mathrm{N}$ fixers and result into low conversion factors. Since we excluded samples with very low oxygen concentrations in the headspace, such bias is unlikely in our study. Furthermore, correlations between ${ }^{15} \mathrm{~N}$ based $\mathrm{N}$ fixation rates and oxygen concentrations in the headspace of the ${ }^{15} \mathrm{~N}$ incubated samples after incubation were not significant and even positive (i.e. they had a tendency to lower rates at lower oxygen concentrations).

High temporal and spatial variability in rates of asymbiotic BNF as shown in our study is commonly reported (e.g. Paul et al. 1971, Vlassak et al. 1973). The relatively low average rates in November 2011 and April 2012 may be explained by low soil temperatures in these months (data not shown); while the low BNF activity in May 2012 may be related to very low soil moisture contents (data not shown). Positive effects of soil moisture on asymbiotic BNF have been shown by several authors under both lab-incubations (e.g. Garten et al. 2007) and field-incubations (e.g. Paul et al. 1971). This is probably related to lower concentrations of oxygen, which may inhibit nitrogenase. The lack of correlation between monthly treatmentmeans of asymbiotic BNF and soil moisture contents in our study suggests that soil moisture may be responsible for the variation in BNF within one treatment and sampling date rather than for seasonal variation. Our data suggest that seasonal variation in BNF was mainly controlled by soil temperature which reduced BNF in cold periods (e.g. Nov, Apr, May) even though soil moisture conditions were favorable.

Our estimates of annual BNF between 1.5 and $4.9 \mathrm{~kg} \mathrm{~N} \mathrm{ha}^{-1} \mathrm{yr}^{-1}$ in the top $0.05 \mathrm{~m}$ soil (Appendix 2) are comparable to the values from the reviews of Reed et al. (2011) and Cleveland et al. (1999) whose estimates of asymbiotic BNF rates were $4.7 \mathrm{~kg} \mathrm{~N} \mathrm{ha}^{-1} \mathrm{yr}^{-1}$ for temperate grasslands and $2.2 \mathrm{~kg} \mathrm{~N} \mathrm{ha}^{-1} \mathrm{yr}^{-1}$ for grasslands worldwide. Rates as high as $21 \mathrm{~kg}$ $\mathrm{N} \mathrm{ha}^{-1} \mathrm{yr}^{-1}$ have been reported by Eisele et al. (1989) for a tallgrass prairie receiving ash while rates below $5 \mathrm{~kg} \mathrm{~N} \mathrm{ha}^{-1} \mathrm{yr}^{-1}$ are usually reported when soil depths between 0.00-0.125 and 0.00-0.60 m are considered (e.g. Paul et al. 1971, Vlassak et al. 1973). However, many of the studies in these reviews have 1) conducted lab-incubations under altered moisture and/or temperature conditions, 2) incubated disturbed soil samples, and/or 3) used theoretical conversion factors for the calculation of BNF rates from $\mathrm{C}_{2} \mathrm{H}_{2}$ reduction. Our results show that conversion factors can deviate substantially from the theoretical value which illustrates that estimates based on a theoretical conversion factor may be biased. Furthermore, our measurements of potential asymbiotic BNF rates revealed that incubation under increased temperature and moisture contents can dramatically increase BNF rates. To our knowledge, the only other study measuring asymbiotic BNF in temperate grasslands that has none of these 
methodological problems estimated asymbiotic BNF at $0.33 \mathrm{~kg} \mathrm{ha}^{-1} \mathrm{yr}^{-1}$ in the upper $0.25 \mathrm{~m}$ of a subalpine meadow in Utah, USA (Skujins et al. 1987). Asymbiotic BNF rates from our study clearly exceeded this estimate even though they were likely to be conservative since we conducted our measurements at the top $0.05 \mathrm{~m}$ of the soil profile only.

How do our estimated of asymbiotic BNF compare to $\mathrm{N}$ deposition and symbiotic BNF of unfertilized ecosystems? In the Solling uplands, $\mathrm{N}$ deposition was $12.6 \mathrm{~kg} \mathrm{~N} \mathrm{ha}^{-1} \mathrm{yr}^{-1}$ (Keuffel-Türk et al., in press). In our study site the abundance of legumes (Trifolium repens) was negligible in the swards cut once per year $(<1 \%$ of the harvested dry mass). In the swards cut three times per year, however, legume abundances were $1.1 \%$ in the fertilized plots and $3.2 \%$ in the unfertilized plots (T. From, unpublished data). According to a model developed by Carlsson and Huss-Danell (2003), the annual $\mathrm{N}$ input $\left(\mathrm{kg} \mathrm{N} \mathrm{ha}^{-1} \mathrm{yr}^{-1}\right)$ in grass-clover mixtures is $3.1 \%$ of the harvested dry mass of Trifolium repens $\left(\mathrm{kg} \mathrm{ha}^{-1} \mathrm{yr}^{-1}\right)$. Based on the biomass yields of 2010 (Keuter et al. 2012) we thus estimate the annual N input through legumes as $\sim 3 \mathrm{~kg} \mathrm{~N}^{-1}$ for the fertilized and $\sim 5 \mathrm{~kg} \mathrm{~N} \mathrm{ha}^{-1}$ for the unfertilized plots. Our results suggest that under favorable management practices, asymbiotic BNF provides a significant input of $\mathrm{N}$ into temperate grassland which is in the same order of magnitude as $\mathrm{N}$ input from atmospheric $\mathrm{N}$ deposition and symbiotic BNF.

\subsubsection{Fertilization and mowing effects on asymbiotic BNF}

Our results that the combined fertilization with $\mathrm{N}$ and $\mathrm{P}$ in a commonly applied mass ratio had a negative effect on asymbiotic BNF supports our first hypothesis. Since BNF is an energyintensive process, bacteria usually only fix $\mathrm{N}_{2}$ when mineral $\mathrm{N}$ is not available (Reed et al. 2011). Underlying mechanisms that can down-regulate $\mathrm{N}$ fixation in response to increasing levels of mineral $\mathrm{N}$ are the inhibition of nitrogenase synthesis by $\mathrm{NO}_{3}{ }^{-}$and the reversible inhibition of nitrogenase activity by $\mathrm{NH}_{4}{ }^{+}$(also called $\mathrm{NH}_{4}{ }^{+}$switch-off mechanism; Yoch and Whiting 1996, Alexander 1977 cited by Patra et al. 2007). Soil mineral N concentrations on the unfertilized plots were probably below the threshold level where nitrogenase inhibition begins. Knowles and Denike (1974) reported that this threshold is dependent on microbial available $\mathrm{C}$ and observed nitrogenase inhibition above $\mathrm{NH}_{4}{ }^{+}-\mathrm{N}$ concentrations $>0.29$ mmole

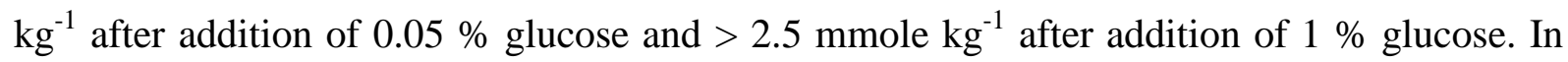
our study site the addition of mineral $\mathrm{N}$ through fertilization led to concentrations above this threshold, value, thus inhibiting nitrogenase activity.

Contrary to the results of Reed et al. (2007), the higher P availability on the fertilized plots did not affect asymbiotic BNF. Potential positive effects of increased $\mathrm{P}$ availability have probably been counteracted by the negative effects of increased soil mineral $\mathrm{N}$ concentrations, 
which supports the theory that mineral $\mathrm{N}$ rather than $\mathrm{P}$ or $\mathrm{N}: \mathrm{P}$ ratios exerts control over asymbiotic BNF (Hartley and Schlesinger, 2002). However, fertilization did not only increase mineral $\mathrm{N}$ and $\mathrm{P}_{\text {resin }}$ concentrations but also mineral $\mathrm{N}: \mathrm{P}_{\text {resin }}$ ratios which may be related to the $\mathrm{N}: \mathrm{P}$ ratio of the applied fertilizer $\left(180 \mathrm{~kg} \mathrm{~N} \mathrm{ha}^{-1} \mathrm{yr}^{-1}\right.$ and $30 \mathrm{~kg} \mathrm{P} \mathrm{ha}^{-1} \mathrm{yr}^{-1}$ ) and the lower mobility of P compared to N. Finally, the overall P availability in our study site may have been too high to be a limiting factor for asymbiotic BNF. Mo was also applied with the fertilizer, but did not have a positive effect either. Thus, our study supports the conclusion of Hartley and Schlesinger (2002) that mineral $\mathrm{N}$ availability was a more important predictor for asymbiotic BNF than Mo availability.

The positive effect of mowing on asymbiotic BNF is probably related to an increase in root exudation following plant-defoliation (Holland et al. 1996). BNF is energy-intensive and since root exudates provide an easily available carbon source for microorganisms (Guitian and Bardgett 2000), an increase in heterotrophic asymbiotic BNF caused by plant-defoliation is likely. Until now this effect was only shown in laboratory incubations and not in the field (Bürgmann et al. 2005). In addition to direct effects as energy sources for $\mathrm{N}$ fixers, root exudates may also promote asymbiotic BNF through an increase in microbial respiration resulting in lower oxygen concentrations (Reed et al. 2011). Both explanations are supported by the higher soil microbial biomass $\mathrm{C}$ and $\mathrm{N}$ contents on the frequently cut plots, which have also been reported by Guitian and Bardgett (2000).

\subsection{Conclusions}

In our study we showed that asymbiotic BNF is an important pathway for the input of $\mathrm{N}$ into unfertilized temperate grasslands and should be considered in the calculation of $\mathrm{N}$ budgets. Fertilization with $\mathrm{N}$ and $\mathrm{P}$ in a commonly applied mass ratio reduced asymbiotic BNF to negligible rates which was probably caused by inhibition of nitrogenase as a result of high mineral $\mathrm{N}$ concentrations. We also demonstrated that intensive mowing stimulated asymbiotic BNF which was probably related to an increase in rhizodeposition, indicating that $\mathrm{C}$ availability is the dominant driver for asymbiotic BNF. Our results furthermore show that conversion factors between $\mathrm{N}_{2}$ fixed and $\mathrm{C}_{2} \mathrm{H}_{2}$ reduced of $<1$ can also occur in temperate grassland soils and that this, together with laboratory incubations may lead to strong biases on estimates of asymbiotic BNF. We suggest that future studies measuring $\mathrm{N}$ inputs from asymbiotic BNF should take these methodological considerations into account. 


\section{Acknowledgements}

This work is part of the Cluster of Excellence 'Functional Biodiversity Research' and has been funded by the State of Lower Saxony, the Ministry of Science and Culture and the Niedersächsisches Vorab. The authors thank Steffen Wolff and Stefanie Herzog for support with field measurements and laboratory work, Dr. Norman Loftfield for his support with the set-up of the gas-chromatograph, and Dirk Boettger for technical assistance. We thank the technical assistants of the Büsgen-Institute and the Department of Plant Ecology for soil analyses. 


\section{References}

Alexander M (1977): Introduction to Soil Microbiology, second edition, Wiley, New York.

Belnap J (2001): Factors influencing nitrogen fixation and nitrogen release in biological soil crusts. In: Belnap J and Lange OL (eds) Biological soil crusts: structure, function and management. Springer, Berlin, pp 241-261.

Brookes PC, Landman A, Pruden G, and Jenkinson DS (1985): Chloroform fumigation and the release of soil nitrogen: A rapid direct extraction method to measure microbial biomass nitrogen in soil. Soil Biology and Biochemistry 17: 837-842.

Bürgmann H, Meier S, Bunge M, Widmer F, and Zeyer J (2005): Effects of model root exudates on structure and activity of a soil diazotroph community. Environmental Microbiology 7: 1711-1724.

Carlsson G and Huss-Danell K (2003): Nitrogen fixation in perennial forage legumes in the field. Plant and Soil 253: 353-372.

Cleveland CC, Townsend AR, Schimel DS, et al. (1999): Global patterns of terrestrial biological nitrogen $\left(\mathrm{N}_{2}\right)$ fixation in natural ecosystems. Global Biogeochemical Cycles 13: 623-645.

Eisele KA, Schimel DS, Kapustka LA, and Parton WJ (1989): Effects of available P and N:P ratios on nonsymbiotic dinitrogen fixation in tallgrass prairie soils. Oecologia 79: 471-474.

Galloway JN, Townsend AR, Erisman JW, et al. (2008): Transformation of the nitrogen cycle: Recent trends, questions, and potential solutions. Science 320: 889-892.

Garten CT Jr, Claasen AT, Norby RJ, Brice DJ, Weltzin JF, and Souza L (2007): Role of $\mathrm{N}_{2}$-fixation in constructed old-field communities under different regimes of $\left[\mathrm{CO}_{2}\right]$, temperature, and water availability. Ecosystems 11: 125-137.

Guitian R and Bardgett RD (2000): Plant and soil microbial responses to defoliation in temperate semi-natural grassland. Plant and Soil 220: 271-277.

Hardy RWF, Holsten RD, Jackson EK, and Burns RC (1968): The acetylene - ethylene assay for $\mathrm{N}_{2}$ fixation: laboratory and field evaluation. Plant Physiology 43: 1185-1207.

Hartley AE and Schlesinger WH (2002): Potential environmental controls on nitrogenase activity in biological crusts of the northern Chihuahuan desert. Journal of arid environments 52: 293-304.

Holland JN, Cheng WX, Crossley DA (1996): Herbivore-induced changes in plant carbon allocation: Assessment of below-ground C fluxes using carbon-14. Oecologia 107: 87-94.

Hyman MR and Arp DJ (1986): Quantification and removal of some contaminating gases from acetylene to study gas-utilizing enzymes and microorganisms. Applied and Environmental Microbiology 53: 298303.

IUSS working group WRB (2006): World reference base for soil resources 2006. World soil resources reports No. 130. FAO, Rome.

Joergensen RG (1996): The fumigation-extraction method to estimate soil microbial biomass: Calibration of the KEC value. Soil Biology and Biochemistry 28: 25-31.

Keuffel-Türk A, Jankowski A, Scheler B, Rademacher P, and Meesenburg H (in press): Stoffeinträge durch Deposition. In: Höper H, Landesamt für Bergbau MH (eds) Tagungsband 20 Jahre BodenDauerbeobachtung in Niedersachsen. Energie und Geologie, Hannover. 
Keuter A, Hoeft I, Corre MD, and Veldkamp E (2012): Nitrogen response efficiency of a managed and phytodiverse temperate grassland. Plant and Soil, DOI 10.1007/s11104-0 12-1344-y.

Knowles R and Denike D (1974): Effect of ammonium, nitrite and nitrate nitrogen on anaerobic nitrogenase activity in soil. Soil Biology and Biochemistry 6: 353-358.

Liengen T (1999): Conversion factor between acetylene reduction and nitrogen fixation in free-living cyanobacteria from high arctic habitats. Canadian Journal of Microbiology 45: 223-229.

Nohrstedt HÖ (1983 a): Conversion factor between acetylene reduction and nitrogen fixation in soil: effect of water content and nitrogenase activity. Soil Biology and Biochemistry 15: 275-279.

Nohrstedt HÖ (1983 b): Natural formation of ethylene in forest soils and methods to correct results given by the acetylene-reduction assay. Soil Biology and Biochemistry 15: 281-286.

Patra AK, Le Roux L, Abbadie L, et al. (2007): Effect of microbial activity and nitrogen mineralization on freeliving nitrogen fixation in permanent grassland soils. Journal of Agronomy and Crop Sciences 193: 153156.

Paul EA, Myers RJK, and Rice WA (1971): Nitrogen fixation in grassland and associated cultivated ecosystems. Plant and Soil, Special Volume: 495-507.

Reed SC, Seastedt TR, Mann CM, Suding KN, Townsend AR, and Cherwin KL (2007): Phosphorus fertilization stimulates nitrogen fixation and increases inorganic nitrogen concentrations in a restored prairie. Applied Soil Ecology 36: 238-242.

Reed SC, Cleveland CC, and Townsend AR (2011): Functional ecology of free-living nitrogen fixation: a contemporary perspective. Annual Review of Ecology, Evolution, and Systematics 42: 489-512.

Skujins J, Tann CC, and Börjesson I (1987): Dinitrogen fixation in a montane forest sere determined by ${ }^{15} \mathrm{~N}_{2}$ assimilation and in situ acetylene-reduction methods. Soil Biology and Biochemistry 19: 465-471.

Tiessen H, Stewart JWB, and Moir JO (1983): Changes in organic and inorganic phosphorus composition of two grassland soils and their particle size fractions during 60-90 years of cultivation. Journal of Soil Science 34: 815-823.

Vitousek PM and Horwarth RW (1991): Nitrogen limitation on land and in the sea - how can it occur? Biogeochemistry 13: 87-115.

Vitousek PM, Aber JD, Howarth RW, et al. (1997): Human alteration of the global nitrogen cycle: sources and consequences. Ecological Applications 7: 737-750.

Vitousek PM, Cassman K, Cleveland C, et al. (2002): Towards an ecological understanding of biological nitrogen fixation. Biogeochemistry 57/58: 1-45.

Vlassak K, Paul EA, and Harris RE (1973): Assessment of biological nitrogen fixation in grassland and associated sites. Plant and Soil 38: 637-649.

Yoch DC and Whiting GJ (1986): Evidence for $\mathrm{NH}_{4}{ }^{+}$switch-off regulation of nitrogenase activity by bacteria in salt marsh sediments and roots of the grass Spartina alterniflora. Applied and Environmental Microbiology: 143-149.

Zechmeister-Boltenstern S and Kinzel H (1990): Non-symbiotic nitrogen fixation associated with temperate soils in relation to soil properties and vegetation. Soil Biology and Biochemistry 22: 1075-1084. 


\section{Appendix}

Appendix 2: Asymbiotic biological nitrogen fixation of a grassland under different management practices and sward compositions in the Solling uplands, Germany. Average measured bulk density of $0.79 \mathrm{~g} \mathrm{~cm}^{-3}$ and a depth from $0.00-0.05 \mathrm{~m}$ was used to convert determined dry mass based rates to area based rates.

\begin{tabular}{|c|c|c|c|c|c|c|c|}
\hline Main factors & Treatments & $\mathrm{n}$ & $\begin{array}{c}\text { sampling } \\
\text { dates }\end{array}$ & $\begin{array}{l}\mathrm{N} \text { fixation rate } \\
\left(\mathrm{mg} \mathrm{N} \mathrm{m} \mathrm{m}^{-2} \mathrm{~d}^{-1}\right)\end{array}$ & $\begin{array}{c}\mathrm{SE} \\
\left(\mathrm{mg} \mathrm{N} \mathrm{m}^{-2} \mathrm{~d}^{-1}\right)\end{array}$ & $P$ & $\begin{array}{l}\text { N fixation rate } \\
\left(\mathrm{kg} \mathrm{N} \mathrm{ha}^{-1} \mathrm{yr}^{-1}\right)\end{array}$ \\
\hline \multirow[t]{4}{*}{ Sward composition } & & & & & & 0.998 & \\
\hline & control & 16 & 9 & $1.0 \mathrm{a}$ & 0.03 & & 2.3 \\
\hline & monocot-enhanced & 16 & 9 & $1.2 \mathrm{a}$ & 0.05 & & 2.5 \\
\hline & dicot-enhanced & 16 & 9 & $1.5 \mathrm{a}$ & 0.09 & & 3.7 \\
\hline \multirow[t]{3}{*}{ Fertilization } & & & & & & 0.017 & \\
\hline & no & 24 & 9 & $1.6 \mathrm{a}$ & 0.07 & & 3.7 \\
\hline & NPK & 24 & 9 & $0.8 \mathrm{~b}$ & 0.02 & & 1.9 \\
\hline \multirow[t]{3}{*}{ Mowing frequency } & & & & & & 0.046 & \\
\hline & once per year & 24 & 9 & $0.9 \mathrm{~b}$ & 0.03 & & 2.0 \\
\hline & thrice per year & 24 & 9 & $1.5 \mathrm{a}$ & 0.06 & & 3.7 \\
\hline \multicolumn{5}{|c|}{ Fertilization : Mowing frequency } & & 0.938 & \\
\hline & no / once per year & 12 & 9 & 1.2 & 0.33 & & 2.4 \\
\hline & NPK / once per year & 12 & 9 & 0.6 & 0.10 & & 1.5 \\
\hline & no / thrice per year & 12 & 9 & 2.0 & 0.56 & & 4.9 \\
\hline & NPK / thrice per year & 12 & 9 & 1.0 & 0.16 & & 2.3 \\
\hline
\end{tabular}

* Rates in $\mathrm{kg}^{-1} \mathrm{ha}^{-1} \mathrm{yr}^{-1}$ were calculated using the trapezoid rule and assuming no activity between Nov $10^{\text {th }} 2011$ and Apr $11^{\text {th }} 2012$ 


\section{SYNTHESIS}

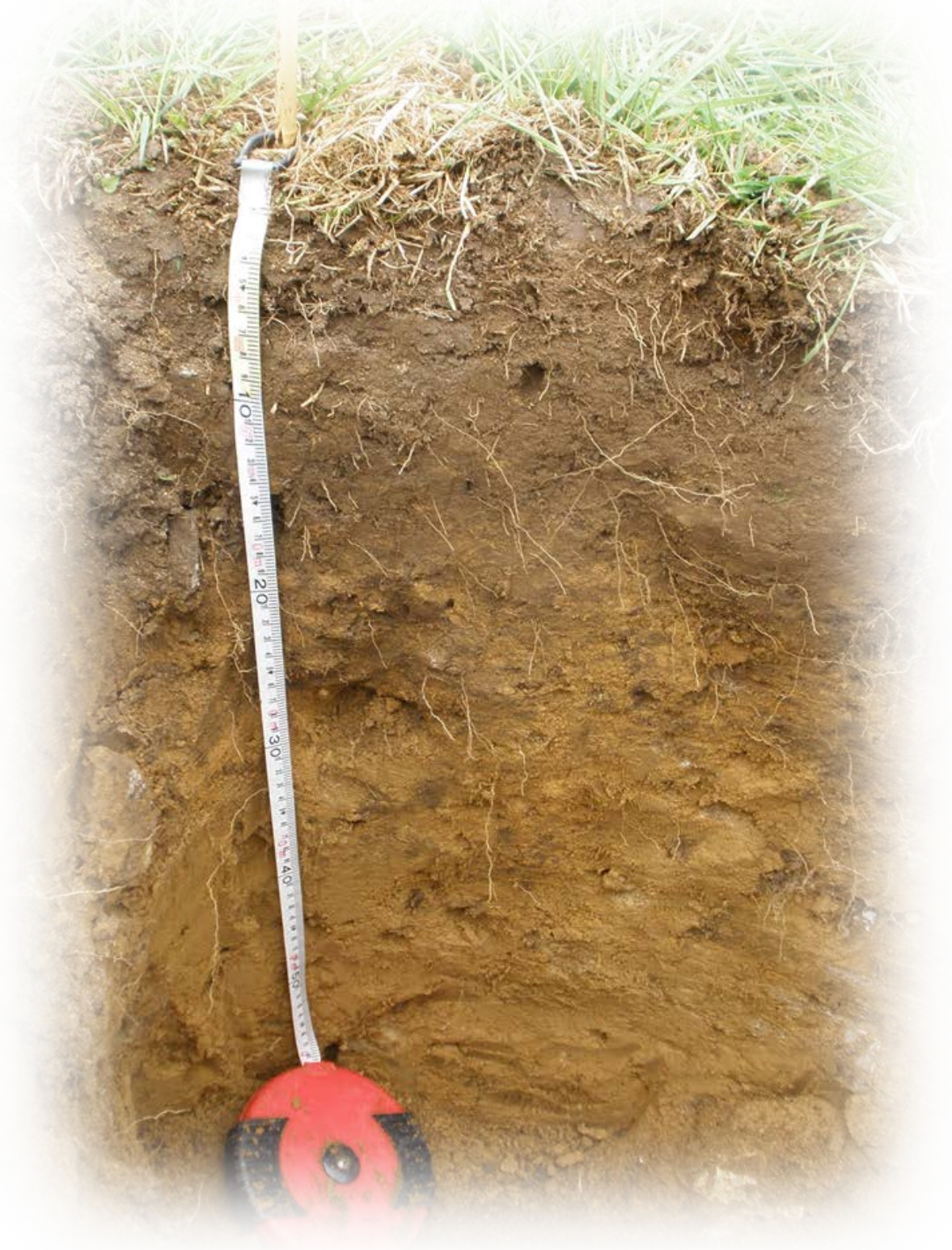




\subsection{Management effects}

Our studies have shown that fertilization was the most influential factor affecting $\mathrm{N}$ cycling and consequently $\mathrm{N}$ losses at our site (Fig. 10). Fertilization was the dominant input of $\mathrm{N}$ to the plant-soil system. However, this input was still relatively low compared to the amount of $\mathrm{N}$ recycled internally (i.e. gross $\mathrm{N}$ mineralization) which was about one order of magnitude higher than the amount of mineral $\mathrm{N}$ applied as fertilizer. This magnitude underlines the importance of $\mathrm{N}$ mineralization for plant growth and becomes plausible when it is related to the amount of microbial $\mathrm{N}$ and total $\mathrm{N}$ in the soil (Fig. 11). This implies the advantage of the $\mathrm{N}$ retention efficiency index as it is calculated in our study (which accounts for gross $\mathrm{N}$ mineralization) over indices considering only external "new" $\mathrm{N}$ inputs (i.e. fertilization or atmospheric N deposition; e.g. Aber et al. 1998).

Fertilization decreased NRE through a decrease in both $\mathrm{N}$ use efficiency and $\mathrm{N}$ uptake efficiency. The latter effect as well as lower microbial $\mathrm{N}$ immobilization rates on the fertilized plots were reflected in higher $\mathrm{N}$ losses (Fig. 10). Since gross $\mathrm{N}$ mineralization was not affected by fertilization this resulted in a decrease in $\mathrm{N}$ retention efficiency as hypothesized. $\mathrm{NO}_{3}{ }^{-}$leaching was the dominant loss pathway in our site under both unfertilized and fertilized conditions (Fig. 10).

Altogether, our studies demonstrate that fertilization is the most important treatment factor for both environmental impacts and biomass yield. The decrease in NRE caused by fertilization, however, points out that the increases in biomass yield are low when related to the amount of fertilizer applied. Long-term experiments have shown that mineral $\mathrm{N}$ fertilizer can cause a depletion of soil total $\mathrm{N}$ and soil organic matter (Khan et al. 2007, Mulvaney et al. 2009). Declines in biomass yield after decades of mineral $\mathrm{N}$ fertilization have been reported for grassland ecosystems (Woude et al. 1994) and cropping systems (Yang et al. 2011). Our results have shown a strong positive effect of fertilization on net $\mathrm{N}$ mineralization in 2009 which we attributed to a priming effect (i.e. higher gross $\mathrm{N}$ mineralization rates). In 2010, however, gross $\mathrm{N}$ mineralization rates were even slightly (not significantly) lower on the fertilized plots. Slight increases in gross $\mathrm{N}$ mineralization after reduction of $\mathrm{N}$ deposition have been observed by Corre and Lamersdorf (2004) for a spruce stand in the Solling Uplands. Sustained fertilization may thus, decrease gross $\mathrm{N}$ mineralization in our site. Gross $\mathrm{N}$ mineralization, being the primary source of mineral $\mathrm{N}$, is crucial for biomass production. Hence, decreases in yield and consequently NRE may also be expected on the fertilized plots over the long-term. Our calculation of $\mathrm{N}$ retention efficiency relates $\mathrm{N}$ losses to gross $\mathrm{N}$ mineralization. $\mathrm{N}$ mineralization is an indicator for soil health and closely correlated to the 
quality and quantity of organic $\mathrm{N}$ and soil microbial biomass (Sparling 1997). $\mathrm{N}$ retention efficiency may, thus, be a more suitable index in evaluating the sustainability of agricultural management practices as opposed to the sole consideration of $\mathrm{N}$ losses and current biomass yields. Fertilization led to decreases in $\mathrm{NH}_{4}{ }^{+}$immobilization in our site. Much more pronounced effects of $\mathrm{N}$ addition on microbial $\mathrm{N}$ immobilization have been observed in longterm grassland experiments after 13 years of mineral $\mathrm{N}$ addition (Ledgard et al. 1998). Since microbial $\mathrm{N}$ immobilization was the dominant pathway for an efficient $\mathrm{N}$ retention at our site further increases in $\mathrm{N}$ losses and decrease in $\mathrm{N}$ retention efficiency might thus, be expected for the fertilized plots over the long term.

Only one fertilization rate (180 $\left.\mathrm{kg} \mathrm{N} \mathrm{ha}^{-1} \mathrm{yr}^{-1}\right)$ was tested in our study. We found a linear decrease in NRE over our range of $\mathrm{N}$ supply but it remains unclear how NRE and $\mathrm{N}$ retention efficiency will react to varying amounts of fertilization. Assuming a non-linear relationship between fertilization rates and NRE (or N retention efficiency), the decrease in NRE (or $\mathrm{N}$ retention efficiency) probably steepens after a certain level of fertilization is exceeded. Such level could serve as a "maximum rate” beyond which yield increases may not anymore justify further fertilization and $\mathrm{N}$ losses. Further studies testing NRE (and N retention efficiency) as a function of fertilization rates should thus, be conducted.

Long-term experiments have shown that organic fertilizers (i.e. manure), as opposed to mineral $\mathrm{N}$ fertilizers, can more efficiently increase soil organic $\mathrm{C}$ and $\mathrm{N}$ contents but do not always influence $\mathrm{N}_{2} \mathrm{O}$ emissions (Meng et al. 2005). Since soil $\mathrm{N}$ and $\mathrm{C}$ are closely correlated with gross $\mathrm{N}$ mineralization (Sparling 1997), it can be assumed that organic fertilizer (i.e. manure) may have a less negative effect on $\mathrm{N}$ retention efficiency than mineral fertilizer. Consequently, further studies should investigate the response of $\mathrm{N}$ retention efficiency to mineral and organic $\mathrm{N}$ fertilizer. Our first study has shown that fertilization dramatically increased net $\mathrm{N}$ mineralization in 2009 which we attributed to a priming effect. In 2010, the difference in net mineralization between fertilized and unfertilized plots was still present but less pronounced. In our second study, however, gross $\mathrm{N}$ mineralization did not differ between the fertilization treatments. A priming effect caused by the addition of mineral $\mathrm{N}$ fertilizer is reflected in an acceleration of soil organic matter turnover due to a lower C: $\mathrm{N}$ ratio (Kuzyakov et al. 2000). Thus, the increase in net $\mathrm{N}$ mineralization following fertilization in 2009 maybe suitably explained by this priming effect. On the other hand, the higher net $\mathrm{N}$ mineralization rates in 2010 may be due to lower microbial immobilization rather than an increase in gross $\mathrm{N}$ mineralization. This is also reflected in the lower $\mathrm{NH}_{4}{ }^{+}$immobilization rates at the fertilized plots measured in our second study. 


\section{a) unfertilized}

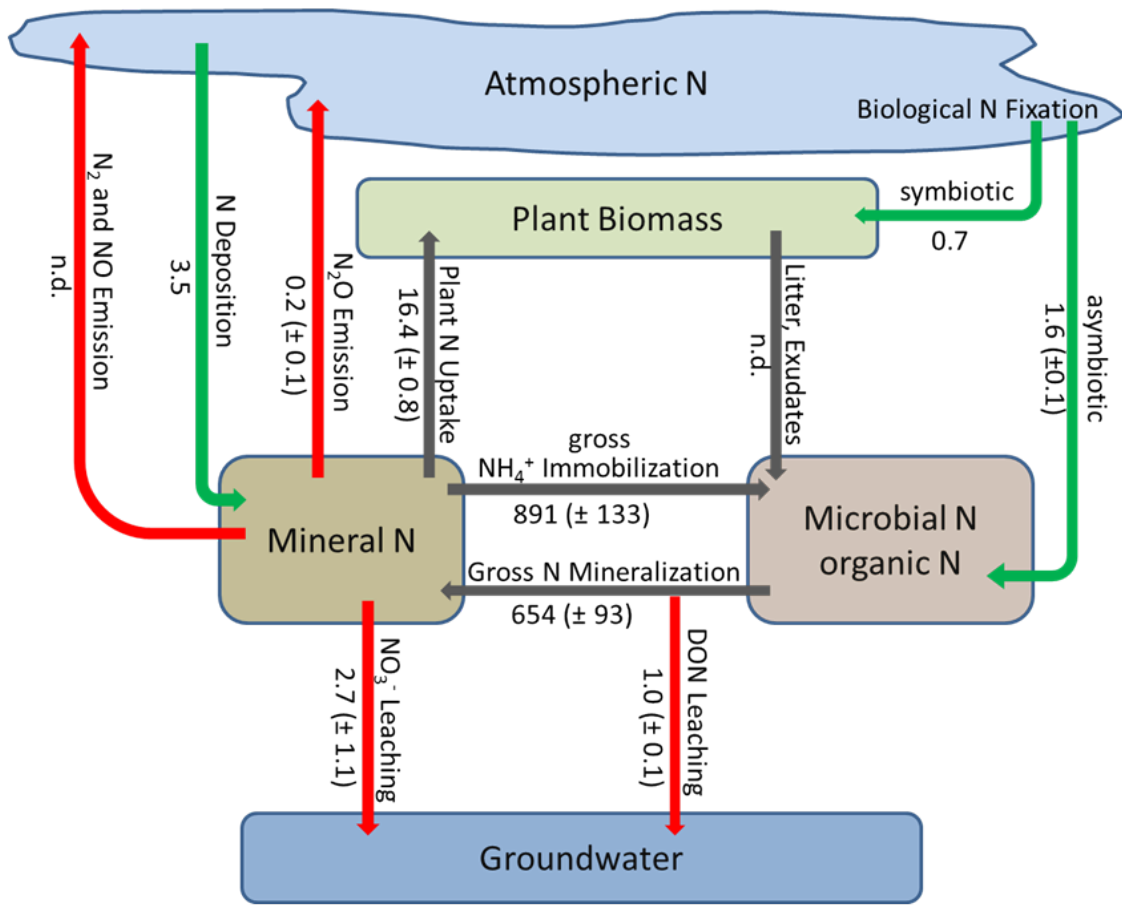

b) fertilized

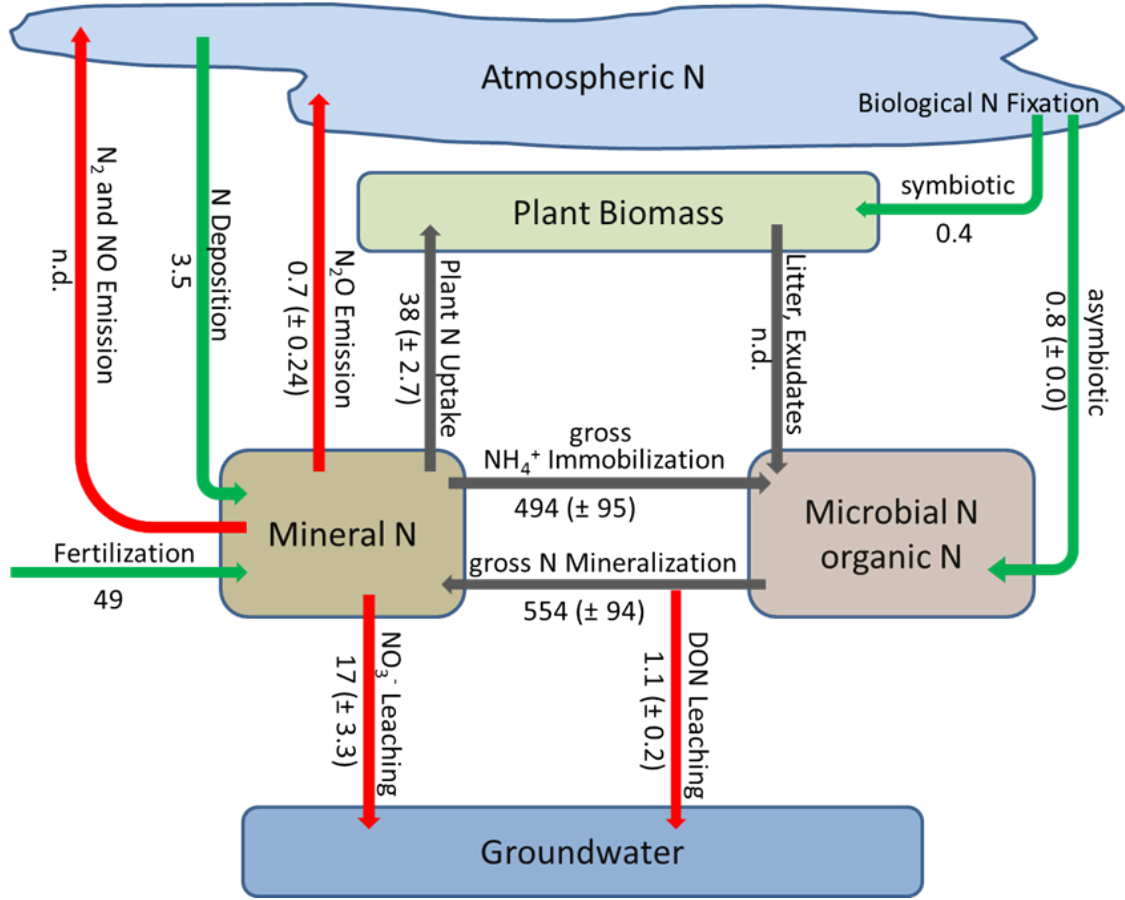

Figure 10: Nitrogen cycling of a grassland in the Solling uplands, Germany under different fertilization treatments $(\mathrm{a}=$ unfertilized, $\mathrm{b}=$ NPK-fertilized) in 2010 (across different sward compositions and mowing frequencies). Gross $\mathrm{N}$ mineralization, $\mathrm{NH}_{4}{ }^{+}$immobilization and asymbiotic $\mathrm{N}$ fixation were measured in a depth of $0.00-0.05 \mathrm{~m}$. Values are means ( \pm Standard error) given in $\mathrm{mg} \mathrm{N} \mathrm{m}^{-2} \mathrm{~d}^{-1}$ (n.d. = not determined). Symbiotic biological $\mathrm{N}$ fixation was calculated as $3.1 \%$ of the harvested biomass of Trifolium repens (T. From, unpublished data) according to Carlsson and Huss-Danell (2003). N deposition was estimated by Keuffel-Türck et al. (in press). Green arrows symbolize external $\mathrm{N}$ inputs, red arrows $\mathrm{N}$ losses and grey arrows internal $\mathrm{N}$ cycling in the plant-soil system. Gross $\mathrm{N}$ mineralization and $\mathrm{NH}_{4}{ }^{+}$immobilization were measured at plots cut once per year only. 


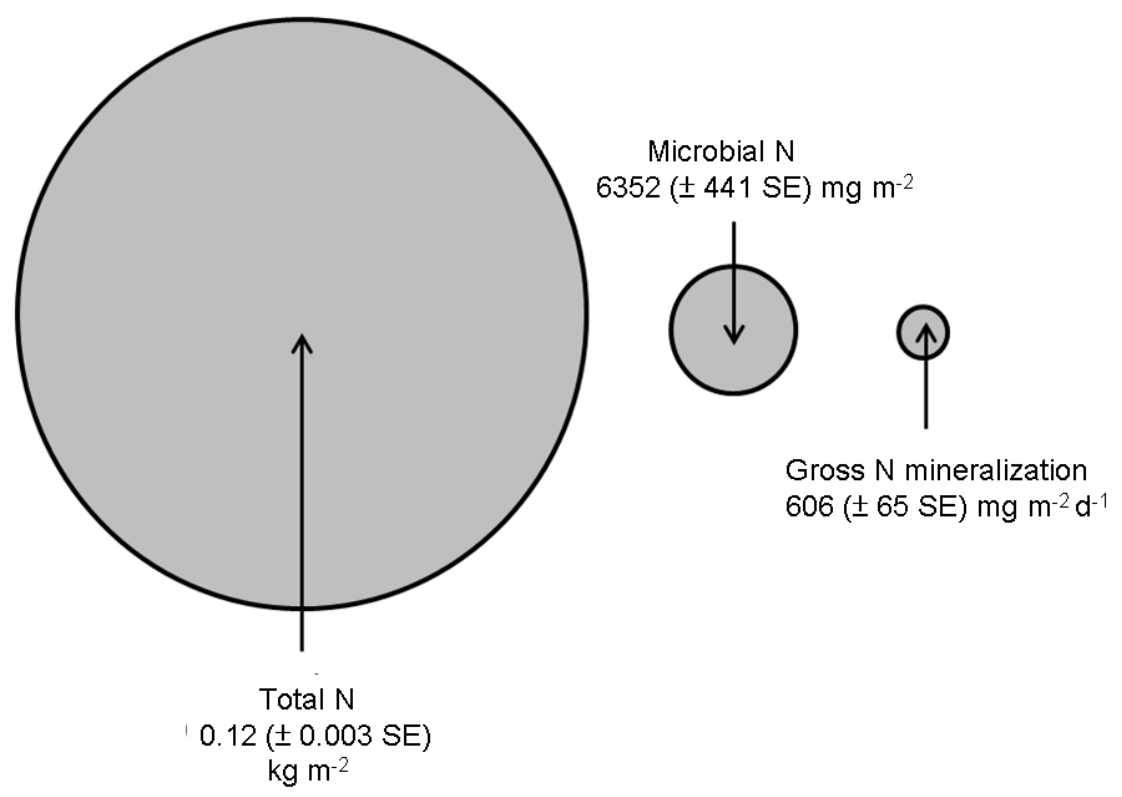

Figure 11: Total N, microbial biomass $\mathrm{N}$ and gross $\mathrm{N}$ mineralization of a grassland in the Solling uplands, Germany in a depth between 0.00 and $0.05 \mathrm{~m}$ (values are means across different management practices and sward compositions \pm standard error). Soil total $\mathrm{N}$ data were provided by I. Hoeft and E. Veldkamp.

As hypothesized, our results demonstrate that frequent mowing increases NRE which was mainly due to a higher $\mathrm{N}$ uptake efficiency. This can be most likely explained by an overcompensatory regrowth (i.e. higher biomass production) following plant-defoliation (Gutian and Bardgett 2000, Ferraro and Oesterheld 2002). The increase in N uptake efficiency caused by frequent mowing was also reflected in lower $\mathrm{N}$ losses. Besides plant $\mathrm{N}$ uptake, microbial $\mathrm{N}$ immobilization also appeared to be responsible for the lower $\mathrm{N}$ losses at the plots cut three times per year. Plant-defoliation has been shown to increase rhizodeposition (Holland et al. 1996). Since root exudates are a source of easily available carbon with a high C:N ratio (Bürgmann 2005), an increase in rhizodeposition may stimulate microbial $\mathrm{N}$ immobilization. This was supported by the larger microbial biomass measured at the plots cut three times per year in our third study. In addition, the lower net $\mathrm{N}$ mineralization rates at the plots cut three times per year in our first study indicated higher microbial $\mathrm{N}$ immobilization. Overall, our results showed that frequent mowing can at least partly compensate for the negative environmental impacts of fertilization.

Interestingly, our third study has also shown that asymbiotic BNF is affected by grassland management practices. As hypothesized, intensive mowing stimulated asymbiotic BNF probably through an increase in rhizodeposition which provides easily available $\mathrm{C}$ for heterotrophic, asymbiotic $\mathrm{N}$ fixers.

Combined fertilization with $\mathrm{N}$ and P decreased asymbiotic BNF which is also in line with our hypothesis. Potentially positive effects of an increased $\mathrm{P}$ availability have probably been 
counteracted by negative effects of an increased mineral $\mathrm{N}$ availability. In previous studies (e.g. Reed et al. 2007), absolute P abundance has been shown to positively affect asymbiotic BNF. $\mathrm{P}$ is also often described as the ultimate limiting nutrient due to its ability to limit $\mathrm{N}$ fixation and thus regulate $\mathrm{N}$ limitation (e.g. Redfield 1958). In contrast, our results indicated that both available $\mathrm{C}$ and $\mathrm{N}$ itself itself regulate asymbiotic BNF rather than the absolute $\mathrm{P}$ abundance .

Asymbiotic BNF provided $\mathrm{N}$ inputs of up to $\sim 5 \mathrm{~kg} \mathrm{ha}^{-1} \mathrm{yr}^{-1}$ under favorable management practices (i.e. unfertilized and cut three times per year) at our study site. Our estimates are likely to be conservative since only the upper $0.05 \mathrm{~m}$ of the soil profile was considered. Assuming a homogenous activity in the whole A horizon (0.1 m thickness), rates of up to $10 \mathrm{~kg} \mathrm{ha}^{-1} \mathrm{yr}^{-1}$ may be expected for unfertilized plots. Thus, our results showed that asymbiotic BNF ranges in the same order of magnitude as the other sources of $\mathrm{N}$ input into the plant-soil system, symbiotic $\mathrm{N}$ fixation and $\mathrm{N}$ deposition.

Reviewed data by Belnap (2001) suggest that asymbiotic $\mathrm{N}$ fixing microorganisms tolerate soil $\mathrm{pH}$ values down to 4. However, $\mathrm{pH}$ values between 6 and 9 are considered favorable. Soil $\mathrm{pH}$ values at our site $(5.3 \pm 0.03 \mathrm{SE})$ are thus, not in the optimum range for asymbiotic BNF and still higher rates may be expected at sites with favorable soil $\mathrm{pH}$. Our gross $\mathrm{N}$ mineralization rates were relatively higher compared to other grassland studies indicating higher soil fertility and $\mathrm{N}$ availability. Since mineral $\mathrm{N}$ is known to inhibit nitrogenase activity (e.g. Yoch and Whiting 1986), higher asymbiotic BNF rates may occur in less fertile grasslands. Moreover, the mean annual temperature at our site of $6.9^{\circ} \mathrm{C}$ is relatively low due to the elevation of $500 \mathrm{~m}$ above sea level. Higher $\mathrm{N}$ inputs by asymbiotic BNF may thus, be possible in lower altitudes.

The $\mathrm{N}$ input by asymbiotic BNF in our site is negligible relative to the amount of $\mathrm{N}$ recycled in the soil by microbial mineralization of organic matter (Fig. 10) or the amount of $\mathrm{N}$ provided by fertilization. Our results thus, point out that asymbiotic BNF plays only a minor role for agriculture and biomass production in a "mature" and intensively managed ecosystem such as ours. Consequently, the consideration of asymbiotic BNF for the calculation of $\mathrm{N}$ supply would only marginally affect our NRE results. However, asymbiotic BNF may be more important in infertile sites that are not fertilized (e.g. organic farming). Globally, asymbiotic BNF may account for a large proportion of the biologically fixed $\mathrm{N}_{2}$. Symbiotic $\mathrm{N}_{2}$ fixers are not abundant in many ecosystems and the presence of potentially symbiotic $\mathrm{N}_{2}$ fixing plant species does not necessarily result in high $\mathrm{N}$ fixation rates (Reed et al. 2011). For instance, there is evidence that $\mathrm{N}_{2}$ fixation rates may substantially differ between nodulated species (Galiana et al. 2002, Sprent 2005) and plants which can nodulate do not always fix $\mathrm{N}_{2}$ 
(Barron et al. 2011). Existing estimates may thus, frequently provide maximum potential rates and consequently, overestimate symbiotic BNF. This challenges the common view that asymbiotic BNF is a less important pathway for biological $\mathrm{N}$ fixation in most ecosystems (Reed et al. 2011). Since grasslands cover an important part of earth's land area (FAO 2008) where leguminous species are not abundant (Reed et al. 2011), our results indicate that asymbiotic BNF in grasslands may significantly contribute to global biological $\mathrm{N}_{2}$ fixation. As such, it is and important pathway to consider in the estimation of $\mathrm{N}$ fixation in the absence of human influences. To estimate the degree of anthropogenic influences and predict future changes in the $\mathrm{N}$ cycle, a better estimate of this "baseline rate" is critically needed (Cleveland et al. 1999, Reed et al. 2011). While anthropogenic increases in $\mathrm{N}$ availability (e.g. increased $\mathrm{N}$ deposition) can substantially alter within-system processes in $\mathrm{N}$ limited ecosystems, they may have a great effect on $\mathrm{N}$ losses in systems where $\mathrm{N}$ is not a limiting factor. Consequently, mechanisms controlling $\mathrm{N}$ limitation determine the consequences of anthropogenic increases in $\mathrm{N}$ availability (Vitousek 2002). Estimates of asymbiotic BNF are incomplete and spatially unresolved (Cleveland et al. 1999, Reed et al. 2011) and knowledge about its ecological controls is sparse (Vitousek 2002). Our third study demonstrated that besides these deficiencies in the quantity of data, existing studies also have methodical discrepancies and thus, may be substantially biased. Consequently, recent estimates of asymbiotic BNF may be even less valid than pointed out by Cleveland et al. (1999), Reed et al. (2011), and Vitousek et al. (2002) based on reviewed data and more studies quantifying asymbiotic BNF without the shortcomings mentioned above (i.e. lab incubations, disturbed soil samples, theoretical conversion factors) are necessary.

\subsection{Sward composition effects}

Besides management practices, sward composition also influenced NRE and $\mathrm{N}$ retention efficiency. Sward composition affected NRE mainly through differences in $\mathrm{N}$ uptake efficiency. Control swards showed significantly higher NRE than dicot-enhanced or monocotenhanced swards (when cut once per year). This pattern could not be explained by differences in species richness since NRE of monocot-enhanced swards (that had the lowest number of species) did not differ from NRE of dicot-enhanced swards. We attributed this missing species richness effect to the range of species richness which clearly is above the range of one to five species, where $90 \%$ of the biodiversity effects on productivity are observed (Roy 2001). In contrast to the number of species, proportions of functional groups had a significant effect on NRE. However, it was not the dicot-enhanced sward with almost equal proportions of dicots and monocots but the untreated control sward that showed the highest NRE. Most likely, 
decades of maintaining extensive management practices and $\mathrm{N}$ limited conditions resulted in a development of the sward to maximize NRE.

The efficient use of available $\mathrm{N}$ may be a strategy of plant communities to compete under N limited conditions (Bridgham et al. 1995). Since competitive advantages of species compositions with a high NRE become more important with decreasing $\mathrm{N}$ availability, it can be expected that sward differences in NRE may increase with decreasing soil fertility. Thus, sward composition effects may be even more pronounced in less fertile grassland ecosystems than ours.

The higher NRE at the control swards mainly attributed to a more efficient $\mathrm{N}$ uptake was reflected in the higher retention efficiency. The sward differences in $\mathrm{N}$ retention efficiency could, however, only partly be explained by plant $\mathrm{N}$ uptake efficiency: The difference in NRE between dicot-enhanced and control swards was not reflected in $\mathrm{N}$ retention efficiency. This can be due to differences in microbial $\mathrm{NH}_{4}{ }^{+}$immobilization which mirrored the differences in $\mathrm{N}$ retention efficiency between the swards (control > dicotenhanced $>$ monocot-enhanced). Across all treatments, $\mathrm{N}$ retention efficiency was correlated with microbial $\mathrm{N}$ and $\mathrm{NH}_{4}{ }^{+}$immobilization rather than with plant $\mathrm{N}$ uptake or harvested biomass. This underlines the importance of the microbial community for an efficient $\mathrm{N}$ retention, which was also reported by Hooper and Vitousek (1997, 1998). In contrast to NRE and $\mathrm{N}$ uptake efficiency that only consider plant uptake as a pathway for $\mathrm{N}$ retention, $\mathrm{N}$ retention efficiency additionally accounts for microbial $\mathrm{N}$ immobilization. Thus, $\mathrm{N}$ retention efficiency is an important index to consider in the evaluation of the sustainability of grassland management.

\subsection{General Conclusions and Recommendations}

Our studies have shown that fertilization was the most important factor influencing NRE, N losses, and $\mathrm{N}$ retention efficiency. Accordingly, a reduction of fertilizer $\mathrm{N}$ application to moderate amounts is crucial to achieving an optimal balance between high soil fertility and productivity on the one hand and low $\mathrm{N}$ losses to the environment on the other hand. Several studies give rise to concerns that negative effects of fertilization on NRE and $\mathrm{N}$ retention efficiency may increase with time (Woude et al. 1994, Ledgard et al. 1998, Khan et al. 2007, Mulvaney et al. 2009, Yang et al. 2011) which highlights the need for studies testing longterm effects of mineral $\mathrm{N}$ fertilization on NRE, $\mathrm{N}$ losses and $\mathrm{N}$ retention efficiency in grasslands. Moreover, further studies should look into the response of NRE to different rates of fertilization.

Frequent mowing increased NRE and could partly compensate for the negative 
environmental effects of fertilization. Mowing frequency influenced net $\mathrm{N}$ mineralization, $\mathrm{N}$ losses, and asymbiotic BNF in our studies most likely due to an increase in rhizodeposition. Further research should focus on this above-ground below-ground interaction and directly quantify the effect of mowing frequency on rhizodeposition.

Besides management, sward composition also influenced NRE and $\mathrm{N}$ retention efficiency, though to a lesser extent. Control swards that have developed under decades of extensive management seem to have developed towards a species composition with a maximum NRE. Alterations of the sward - even if they resulted to more balanced proportions of plant functional groups - lowered NRE. Such results draw attention to the negative effects of herbicide use in grasslands. Particularly for regions where mineral fertilizer is difficult to procure and where a high NRE is consequently of prime importance (e.g. in developing countries), this should be taken into consideration. Since the efficient use of available N may be a strategy of plants to compete in infertile environments (Bridgham et al. 1995), sward effects on NRE may be even more pronounced in less fertile grasslands. Further studies testing sward composition effects on NRE should thus, be conducted in N-poor grassland ecosystems. The sward effect was caused by plant functional group composition rather than the number of species present. As pointed out by Wrage et al. (2011), the number of species in permanently managed grassland may be too high to detect species richness effects on productivity. Our studies showed that this may also hold true for NRE and N retention efficiency. Against this background, the suitability for practical applications of previous biodiversity studies in artificial grasslands is questionable. Further studies aiming at practical applications should thus, test effects of functional group compositions on NRE or N retention efficiency rather than effects of plant species numbers in permanent grasslands.

We could show that gross $\mathrm{N}$ mineralization was the most important pathway providing mineral N, highlighting the importance of accounting for this process when losses are related to $\mathrm{N}$ availability or soil fertility. In addition, our results indicated that microbial $\mathrm{N}$ immobilization was the dominant mechanism behind the effects of management and sward composition on $\mathrm{N}$ retention. $\mathrm{N}$ retention efficiency, as calculated in our study, accounts for this pathway. In contrast to the sole consideration of (absolute) $\mathrm{N}$ losses, $\mathrm{N}$ retention efficiency relates $\mathrm{N}$ losses to gross $\mathrm{N}$ mineralization (as an index for soil fertility) which made it a more sensitive parameter. Hence, it is a suitable index to evaluate the sustainability of agricultural management practices. Due to potentially different effects on gross $\mathrm{N}$ mineralization and $\mathrm{N}$ losses, further studies should focus on the response of $\mathrm{N}$ retention efficiency to organic and inorganic fertilizers. The combined consideration of NRE and N retention efficiency provides a tool that accounts for biomass yield, gross $\mathrm{N}$ mineralization as 
a measure of soil fertility and an indicator of soil health, and $\mathrm{N}$ losses to the environment.

Our third study showed that asymbiotic BNF can provide an important input of "new" $\mathrm{N}$ to unfertilized grasslands and that previous estimates on asymbiotic BNF may be substantially biased due to methodical discrepancies. Our results indicated that asymbiotic $\mathrm{BNF}$ is of subordinate importance for plant-growth in intensively used agricultural ecosystems since the amounts of $\mathrm{N}$ provided by either $\mathrm{N}$ mineralization or fertilization are considerably higher. On a global scale, however, it may be an important pathway for BNF that may substantially contribute to the amount of $\mathrm{N}$ fixed in the absence of human activities. Thus, it is an important parameter for the estimation of the degree of human changes to the $\mathrm{N}$ cycle. Further research to quantify asymbiotic BNF is thus, critically needed. Frequent mowing increased asymbiotic BNF while combined fertilization with $\mathrm{N}$ and P decreased it. Since the overall $\mathrm{P}$ availability in our study site is relatively high, a different result maybe expected with $\mathrm{N}$ and $\mathrm{P}$ fertilization under low $\mathrm{P}$ availability. Additional studies testing the effect of combined fertilization with $\mathrm{N}$ and $\mathrm{P}$ should, thus, be conducted under P-limited conditions.

Our first and second study demonstrated that sward functional group composition can influence $\mathrm{N}$ uptake efficiency and $\mathrm{N}$ retention efficiency due to higher plant $\mathrm{N}$ uptake and microbial $\mathrm{N}$ immobilization. Decreasing mineral $\mathrm{N}$ concentrations with increasing plant diversity have also been reported by other authors (e.g. Tilman et al. 1996). Since N availability is an important factor controlling asymbiotic BNF, this leads to the assumption that sward composition may also affect asymbiotic BNF. Thus, future research should be conducted on the effect of species diversity on asymbiotic BNF. 


\section{References}

Aber J, McDowell W, Nadelhoffer K, et al. (1998): Nitrogen saturation in temperate forest ecosystems. Bioscience 48: 921-934.

Accoe F, Boeckx P, Buschaert J, Hofman G, and van Cleemput O (2004): Gross N transformation and net N mineralization rates related to the $\mathrm{C}$ and $\mathrm{N}$ contents of soil organic matter fractions in grassland soils of different age. Soil Biology Biochemistry 36: 2075-2087.

Barron AR, Purves DW, and Hedin LO (2011): Facultative nitrogen fixation by canopy legumes in a lowland tropical forest. Oecologia 165: 511-520.

Belnap J (2001): Factors influencing nitrogen fixation and nitrogen release in biological soil crusts. In: Belnap J and Lange OL (eds) Biological soil crusts: structure, function and management. Springer, Berlin, pp 241-261

Bridgham SD, Pastor J, Mc Claugherty CA, and Richardson CJ (1995): Nutrient-use efficiency - a litterfall index, a model, and a test along a nutrient-availability gradient in North-Carolina peatlands. The American Naturalist 145: 1-21.

Bürgmann H, Meier S, Bunge M, Widmer F, and Zeyer J (2005): Effects of model root exudates on structure and activity of a soil diazotroph community. Environmental Microbiology 7: 1711-1724.

Carlsson G and Huss-Danell K (2003): Nitrogen fixation in perennial forage legumes in the field. Plant and Soil 253: 353-372.

Cleveland CC, Townsend AR, Schimel DS, et al. (1999): Global patterns of terrestrial biological nitrogen $\left(\mathrm{N}_{2}\right)$ fixation in natural ecosystems. Global Biogeochemical Cycles 13: 623-645.

Corre MD and Lamersdorf NP (2004): Reversal of nitrogen saturation after long-term deposition reduction: Impact on soil nitrogen cycling. Ecology 85: 3090-3104.

FAO (2008): Are grasslands under threat? Brief analysis of FAO statistical data on pasture and fodder crops. http://www.fao.org/ag/agp/agpc/doc/grass_stats/grass-stats.htm.

Ferraro DO and Oesterheld M (2002): Effect of defoliation on grass growth. A quantitative review. Oikos 98: 125-133.

Galiana A, Balle P, Kanga AN, and Domenach AM (2002): Nitrogen fixation estimated by the $15 \mathrm{~N}$ natural abundance method in Acacia mangium Willd inoculated with Bradyrhizobium sp. and grown in silvicultural conditions. Soil Biology and Biochemistry 34: 251-261.

Guitian R and Bardgett RD (2000): Plant and soil microbial responses to defoliation in temperate semi-natural grassland. Plant and Soil 220: 271-277.

Holland JN, Cheng WX, Crossley DA (1996): Herbivore-induced changes in plant carbon allocation: Assessment of below-ground C fluxes using carbon-14. Oecologia 107: 87-94.

Hooper DU and Vitousek PM (1997): The effects of plant composition and diversity on ecosystem processes. Science 277: 1302-1305.

Hooper DU and Vitousek PM (1998): Effects of plant composition and diversity on nutrient cycling. Ecological Monographs 68: 121-149.

Keuffel-Türk A, Jankowski A, Scheler B, Rademacher P, and Meesenburg H (in press): Stoffeinträge durch Deposition. In: Höper $\mathrm{H}$, Landesamt für Bergbau MH (eds) Tagungsband 20 Jahre BodenDauerbeobachtung in Niedersachsen. Energie und Geologie, Hannover. 
Khan SA, Mulvaney RL, Ellsworth TR, and Boast CW (2007): The myth of nitrogen fertilization for soil carbon sequestration. Journal of Environmental Quality 36: 1821-1832.

Kuzyakov Y, Friedel JK and Stahr K (2000): Review of mechanisms and quantification of priming effects. Soil Biology and Biochemistry 32: 1485-1498.

Ledgard SF, Jarvis SC, and Hatch DJ (1998): Short-term nitrogen fluxes in grassland soils under different longterm nitrogen management regimes. Soil Biology and Biochemistry 30: 1233-1241.

Meng L, Ding W, and Cai (2005): Long-term application of organic manure and nitrogen fertilizer on $\mathrm{N}_{2} \mathrm{O}$ emissions, soil quality and crop production in a sandy loam soil. Soil Biology and Biochemistry 37: 2037-2045.

Mulvaney RL, Khan SA, and Ellsworth TR (2009): Synthetic nitrogen fertilizers deplete soil nitrogen: a global dilemma for sustainable cereal production. Journal of Environmental Quality 38: 2295-2314.

Redfield AC (1958): The biological control of chemical factors in the environment. American Scientist 64: 205-221.

Reed SC, Seastedt TR, Mann CM, Suding KN, Townsend AR, and Cherwin KL (2007): Phosphorus fertilization stimulates nitrogen fixation and increases inorganic nitrogen concentrations in a restored prairie. Applied Soil Ecology 36: 238-242.

Reed SC, Cleveland CC, and Townsend AR (2011): Functional ecology of free-living nitrogen fixation: a contemporary perspective. Annual Review of Ecology, Evolution, and Systematics 42: 489-512.

Roy J (2001): How does biodiversity control primary productivity? In: Roy J, Saugier B, and Mooney HA (eds) Terrestrial global productivity. Academic Press, San Diego, pp 169-186.

Sparling GP (1997): Soil microbial biomass, activity and nutrient cycling as indicators of soil health. In: Pankhurs CE, Double BM, and Gupta VVSR (eds): Biological indicators of soil health. CAB International. New York, USA.

Sprent JI (2005): Nodulated legume trees. In: Werner D and Newton WE (eds) Nitrogen fixation in agriculture, forestry and the environment. Amsterdam: Springer. pp. 113-141.

Tilman D, Wedin D, and Knops J (1996): Productivity and sustainability influenced by biodiversity in grassland ecosystems. Nature 379: 718-720.

Vitousek PM, Cassman K, Cleveland C, et al. (2002): Towards an ecological understanding of biological nitrogen fixation. Biogeochemistry 57/58: 1-45.

Woude BJ von der, Pegtel DM, and Bakker JP (1994): Nutrient limitation after long-term nitrogen fertilizer application in cut grasslands. Journal of applied ecology 31: 405-412.

Wrage N, Strodthoff J, Cuchillo HM, Isselstein J, and Kayser M (2011): Phytodiversity of temperate permanent grasslands: ecosystem services for agriculture and livestock management for diversity conservation. Biodiversity and Conservation 20: 3317-3339.

Yang X, Yang Y, Sun B, and Zhang S (2011): Long-term fertilization effects on yield trends and soil properties under a winter wheat-summer maize cropping system. African Journal of Agricultural Research 6: 3392-3401.

Yoch DC and Whiting GJ (1986): Evidence for $\mathrm{NH}_{4}{ }^{+}$switch-off regulation of nitrogenase activity by bacteria in salt marsh sediments and roots of the grass Spartina alterniflora. Applied and Environmental Microbiology: 143-149. 


\section{Danksagung}

An dieser Stelle möchte ich mich bei Herrn Professor Dr. Veldkamp für die Vermittlung des Stipendiums sowie für die ausgezeichnete Betreuung meiner Arbeit und die zahlreichen guten fachlichen Ratschläge bedanken. Besonderen Dank schulde ich auch meiner Betreuerin, Frau Dr. Marife D. Corre, die stets engagiert und hilfsbereit war, sowie Frau Professor Dr. Nicole Wrage für die gute Betreuung trotz großer Entfernung und besonders für die Begutachtung meines ersten Manuskriptes. Des Weiteren möchte ich allen Kollegen und den Doktoranden des GRASSMAN-Teams für eine gute gemeinsame Zeit danken - den Einbau der 144 Lysimeter im steinigen Boden des Solling werden wir alle sicher nie vergessen. Trotz der Anstrengung hat es viel Spaß gemacht und das zeichnet ein gutes Team aus. Dann waren da natürlich die „Hiwis“ (Christoph Gottwald, Niels Meyer, Stefanie Herzog und nicht zuletzt Steffen Wolf), die so manche Stunde bei miserablen Witterungsverhältnissen im kalten (und windigen...) Solling ausgeharrt haben und mich stets tatkräftig bei der Feldarbeit unterstützt haben. Die technischen Assistenten des Büsgen-Instituts, allen voran Karin Schmidt, die mir so oft mit Rat und Tat zur Seite stand, möchte ich an dieser Stelle ebenso nennen. Auch Dr. Norman Loftfield hat mir - besonders bei den zahlreichen Problemen mit den Gaschromatographen - sehr geholfen und sei daher hier erwähnt. Ganz besonders hervorheben möchte ich meine Kollegin Dr. Ina Hoeft. Ich habe die Zusammenarbeit mit ihr immer als sehr angenehm und motivierend empfunden.

Zu guter Letzt möchte ich meinen Eltern danken, die mich während meiner (langen...) Studien immer unterstützt haben. 


\section{Eidesstattliche Erklärung}

Hiermit versichere ich, Andreas Keuter, geboren am 27.01.1981 in Warendorf, dass ich die vorliegende Arbeit selbständig verfasst habe und keine weiteren als die aufgeführten Quellen und Hilfsmittel verwendet habe.

Göttingen, den 08. Januar 2013

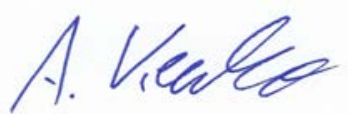

(Andreas Keuter) 


\section{Curriculum vitae}

\section{Personal Information}

Name:

Date of birth:

Place of birth:

\section{Education}

since 2010

2007 - 2010

$2001-2007$

$1991-2000$
Andreas Keuter

27. January 1981

Warendorf
Ph.D. student at the Georg-August-University of Göttingen, BüsgenInstitute, Soil Science of tropical and subtropical Ecosystems: Scholarship in the Cluster of Excellence „Functional Biodiversity Research“

Studies at the University of Applied Sciences, Osnabrück in Soil Use and Soil Protection.

Master-Thesis: „Untersuchung an einer aerob verrotteten Mülldeponie im Hinblick auf toxische Eigenschaften, Mineralisierung und Verdichtbarkeit““

Studies at the University of Osnabrück in Physical Geography /

Geoecology; minor subjects: Ecology, Law

Diploma-Thesis: „Die Gewässerstrukturgüte der Düte“

Mariengymnasium Warendorf: Abitur

\section{Scientific Publications}

KEUTER A, FRÜND HC, KERTH M (2011): From waste to soil—carbon contents, respiration rates and ecotoxicological effects of an uncovered landfill site after 50 years. Journal of Soils and Sediments 11: 93-10.

KEUTER A., HOEFT I., CORRE M. D. AND VELDKAMP E. (2012): Nitrogen response efficiency of a managed and phytodiverse temperate grassland. Plant and Soil. DOI 10.1007/s11104-0 12-1344-y.

\section{Conferences}

HOEFT I, KEUTER A, VELDKAMP E, AND CORRE MD (2011): Nitrogen response efficiency of a managed and phytodiverse temperate semi-natural grassland. Functions and services of biodiversity, Göttingen (Poster).

KEUTER A, HOEFT I, VELDKAMP E, CORRE MD, QUINONES CM AND SCHMIDT-WALTER P (2012): Nitrogen retention efficiency and nitrogen losses of a managed and phytodiverse temperate grassland. EGU General Assembly, Wien (Talk).

KEUTER A, VELDKAMP E, and CORRE MD (2012): Asymbiotic biological nitrogen fixation in a temperate grassland under different management practices. Regulation of soil organic matter and nutrient turnover in agriculture, Witzenhausen (Talk).

KEUTER A, HOEFT I, VELDKAMP E, AND CORRE MD (2012): Nitrogen retention efficiency and nitrogen losses of a managed and phytodiverse temperate grassland. Regulation of soil organic matter and nutrient turnover in agriculture, Witzenhausen (Poster). 